UNIVERSIDADE DE SÃO PAULO

FACULDADE DE FILOSOFIA LETRAS E CIÊNCIAS HUMANAS

ROSA MARIA LAQUIMIA DE SOUZA

Similaridades e diferenças: o negro nos Estados Unidos da América e no Brasil segundo Alice Walker e Conceição Evaristo 
ROSA MARIA LAQUIMIA DE SOUZA

\section{Similaridades e diferenças: o negro nos Estados Unidos da América e no Brasil segundo Alice Walker e Conceição Evaristo}

Tese apresentada à Faculdade de Filosofia Letras e Ciências Humanas da Universidade de São Paulo para obtenção do título de Doutor em Letras

Área de Concentração: Estudos Lingüísticos e Literários em Inglês Orientadora: Maria Elisa Burgos Pereira da Silva Cevasco

São Paulo 
AUTORIZO A REPRODUÇÃO E DIVULGAÇÃO TOTAL OU PARCIAL DESTE TRABALHO, POR QUALQUER MEIO CONVENCIONAL OU ELETRÔNICO, PARA FINS DE ESTUDO E PESQUISA, DESDE QUE CITADA A FONTE.

Catalogação na Publicação

Serviço de Biblioteca e Documentação

Faculdade de Filosofia, Letras e Ciências Humanas da Universidade de São Paulo STAMIC

Souza, Rosa Maria Laquimia de

Similaridades e diferenças: o negro nos Estados Unidos da América e no

Brasil segundo Alice Walker e Conceição Evaristo / Rosa Maria Laquimia de Souza ; orientadora Maria Elisa Burgos Pereira da Silva Cevasco. -- São Paulo, 2008.

$168 \mathrm{p}$.

Tese (Doutorado - Programa de Pós-Graduação em Estudos Linguísticos e Literários em Inglês - Departamento de Letras Modernas) Faculdade de Filosofia, Letras e Ciências Humanas da Universidade de São Paulo.

1. Literatura. 2. Racismo - História. 3. Sociedade I. Título. II. Cevasco, Maria Elisa Burgos Pereira da Silva. 


\section{FOLHA DE APROVAÇÃO}

Rosa Maria Laquimia de Souza

Similaridades e diferenças: o negro nos Estados Unidos da América e no Brasil segundo Alice Walker e Conceição Evaristo

Tese apresentada à Faculdade de Filosofia Letras e Ciências Humanas da Universidade de São Paulo para obtenção do título de Doutor.

Área de Concentração: Estudos Lingüísticos e Literários em Inglês

Aprovado em:

\section{Banca Examinadora}

Prof. Dr.

Instituição:

Assinatura:

Prof. Dr.

Instituição:

Assinatura:

Prof. Dr.

Instituição:

Assinatura:

Prof. Dr.

Instituição:

Assinatura:

Prof. Dr.

Instituição: Assinatura: 


\section{DEDICATÓRIA}

Em memória de Antonio Laquimia e Ignez Milani Laquimia, meus pais, que em sua trajetória de vida me presentearam com exemplos de honestidade, integridade, ética e perseverança. 


\section{AGRADECIMENTOS}

À Profa. Dra. Maria Elisa Burgos Pereira da Silva Cevasco, pela orientação eficiente e segura.

Ao Prof. Dr. Lynn Mario T. M. de Souza, pela atenção e pelos conselhos sempre enriquecedores.

À Faculdade de Filosofia Letras e Ciências Humanas, pela oportunidade de realização do curso de doutorado.

Aos meus queridos Ana Elisa, Lucas e Mário, pelo carinho, paciência e apoio constantes. 


\section{RESUMO}

SOUZA, R. M. L. de. Similaridades e diferenças: o negro nos Estados Unidos da América e no Brasil na visão de Alice Walker e Conceição Evaristo. 2008. $154 \mathrm{f}$. Tese (Doutorado) - Faculdade de Filosofia Letras e Ciências Humanas, Universidade de São Paulo, São Paulo, 2008.

Os Estados Unidos da América e o Brasil são países que durante séculos fizeram uso intenso da mão-de-obra escrava, trazida de diferentes regiões da África. Após a Abolição da Escravidão os dois países adotaram políticas diferentes de relações raciais, com conseqüências devastadoras para os ex-escravos e seus descendentes. Alice Walker e Conceição Evaristo, autoras afro-americana e afro-brasileira, respectivamente, apresentam em seus romances uma análise das relações étnicas em seus países, apontando a origem dos problemas da população negra e propondo soluções para os mesmos. Através de uma análise comparativa dos dois romances - The third life of Grange Copeland e Ponciá Vicêncio - sob a ótica da crítica literária marxista, este trabalho propõe-se a apresentar os pontos em comum e os pontos divergentes entre as duas sociedades. Norteada pela relação entre literatura, história e sociedade, a análise das duas obras vem demonstrar que, embora aparentemente antagônicos, os dois países são extremamente racistas, dominados por relações de opressão derivadas de um sistema econômico regido pelo consumo e pelo lucro, e de uma cultura que não aceita a diferença - no caso dos Estados Unidos, declaradamente, e no caso do Brasil, mascarada pela imagem de "paraíso racial". Como conseqüência, verifica-se que a cultura opressora dos dois países é tão arraigada que ambas as autoras não conseguem vislumbrar uma solução plausível para o problema, que consiga fugir dos conceitos sócio-políticos solidamente erigidos através dos séculos.

Palavras chave: Literatura. Racismo. História. Sociedade. 


\begin{abstract}
SOUZA, R. M. L. de. Similarities and differences: the Black in The United States of America and in Brazil according to Alice Walker and Conceição Evaristo. 2008. 154 f. Thesis (Doctoral) - Faculdade de Filosofia Letras e Ciências Humanas, Universidade de São Paulo, São Paulo, 2008.

The United States of America and Brazil made use of African slave labour for centuries. After the end of the slavery system both countries adopted different racial policies, with devastating consequences both to ex-slaves and their descendents. Alice Walker and Conceição Evaristo, afro-American and afro-Brazilian writers, respectively, present in their novels an analysis of the ethnical relations in their countries, pointing out the origin of the Black community problems and proposing a way to solve them. Through the comparative analysis of both novels - The third life of Grange Copeland and Ponciá Vicêncio - under the Marxist literary criticism approach, this study aims at presenting both the common and the different aspects of the two societies. Centred on the relationship among literature, history and society, the analysis of both works demonstrates that, although apparently unlike, the two countries are extremely racist, permeated by oppressive relations derived from an economical system guided by consumerism and profit, and by a culture which does not accept difference - openly in The United States of America, and, in Brazil, disguised under the image of "racial paradise". As a consequence, it becomes clear that the oppressive culture of both countries is so deeply rooted that neither writer is able to find a plausible solution to the problem, one that could escape from the socio-political concepts solidly built through centuries.
\end{abstract}

Keywords: Literature. Racism. History. Society. 


\section{SUMÁRIO}

1 INTRODUÇÃOO 10

2 THE THIRD LIFE OF GRANGE COPELAND 23

2.1 A MISÉRIA DOS COPELAND E AS TEORIAS DE FRANTZ FANON 28

2.2 O ENCONTRO ENTRE FICÇÃO E HISTÓRIA 39

2.3 BROWNFIELD COPELAND 49

3 PONCIÁ VICÊNCIO $\quad 64$

3.1 A TRAJETÓRIA DE PONCIÁ 70

3.2 ESPAÇOS PERCORRIDOS

$\begin{array}{ll}3.3 \text { O BARRO } & 86\end{array}$

3.4 A FAMÍLIA VICÊNCIO E O BRASIL 92

3.5 OS HOMENS E A FAMÍLIA 95

3.6 GRANGE COPELAND E VÔ VICÊNCIO 101

3.7 LUANDI JOSÉ VICÊNCIO 111

3.8 A FAMÍLIA 116

$\begin{array}{ll}\text { 3.9 UM PARALELO } & 121\end{array}$

4 LIMITES

$\begin{array}{ll}\text { 4.1 EM TERRAS BRASILEIRAS... } & 143\end{array}$

$\begin{array}{ll}\text { BIBLIOGRAFIA } & 152\end{array}$ 


\section{INTRODUÇÃO}

O Brasil tem a maior população negra fora da África e a segunda maior do planeta. O único país do mundo com uma população negra que supera a brasileira é a Nigéria, com cerca de 85 milhões de habitantes.

Tamanho número de habitantes afro-descendentes deve-se ao fato de o Brasil ter sido o responsável pelo maior translado humano da História: do século XVI até o final do século XIX, entre 3,6 e 5 milhões de africanos foram trazidos para o Brasil, oriundos de diversas partes da África. ${ }^{1}$

Seria natural, portanto, que a sociedade brasileira tivesse expoentes da raça negra atuando em todos os setores que a constituem. No entanto, a realidade é bem diferente: a igualdade racial está presente apenas na música e nos esportes mais populares. Vítima do discurso da democracia racial, construído sob a ótica da classe dominante - branca, de origem européia - e amplamente divulgado, a população negra brasileira mantém-se, em sua imensa maioria, à margem da sociedade.

O campo das artes, mais especificamente a literatura, não se revela diferente. A tradição literária brasileira apresenta um número insignificante de escritores negros ou mestiços que tenham feito uso da ficção para trabalhar com a temática da condição do negro em nossa sociedade.

No século XIX, encontramos Machado de Assis - um dos mais importantes escritores brasileiros - e Lima Barreto - engajado na tradição realista e social - ambos frutos da miscigenação e de origem humilde.

Embora desfrutasse grande prestígio e, portanto, tivesse a possibilidade de discutir abertamente a condição do negro na sociedade brasileira de sua época, Machado

\footnotetext{
${ }^{1}$ IANNI, Octavio. Escravidão e Racismo. São Paulo: Hucitec, 1988. 190 p.
} 
adotou uma postura não panfletária, apresentando o tema de maneira sutil e "dissimulada". O alto grau de acomodação aos valores patriarcais e paternalistas profundamente arraigados em nossa cultura, aliado à deficiente formação cultural que dominava a sociedade brasileira do século XIX, impedia seus leitores de enxergar além da superfície de seus romances e contos.

Inteligentes e irônicos, seus escritos pressupõem uma leitura minuciosa e distanciada para que seja possível compreender sua representação das complexas relações sociais e raciais inerentes ao Brasil de seu tempo. Foi necessária a passagem de mais de meio século para que os críticos literários começassem a enxergar a profundidade de sua obra e tal feito tornou-se brilhantemente real com as inteligentes e perspicazes análises de sua produção literária realizadas por Roberto Schwarz, sem dúvida o maior especialista contemporâneo em Machado de Assis.

Enquanto isto não acontecia, ele foi acusado por alguns críticos, como Sergio Buarque de Holanda, de ter renegado suas origens e ter se identificado com a burguesia - branca - de seu tempo.

O certo é que, apesar de tudo quanto podiam ter de comum, os dois romancistas cariocas (Machado de Assis e Lima Barreto) se separavam num ponto essencial. Enquanto os escritos de Lima Barreto foram, todos eles, uma confissão mal disfarçada, os de Machado foram antes uma evasão e um refúgio. $\mathrm{O}$ mesmo tema que para o primeiro representa obsessivo tormento e tormento que não pode calar, este o dissimula por todos os meios ao seu alcance. E afinal triunfa na realização literária, onde a dissimulação cuidadosamente cultivada irá expandir-se até o ponto de se converter no ingrediente necessário de uma arte feita de vigilância, de reserva e de tato. Machado de Assis aristocratizou-se por esforço próprio e da disciplina que para isso se impôs, ficou em seu temperamento e em sua obra uma 
vertente inumana, que deveria desagradar a espíritos menos capazes de contensão. Desagradaria, como se sabe, a um Patrocinio e desagradou certamente a Lima Barreto. ${ }^{2}$

Lima Barreto, por sua vez, não parece preocupado em renunciar a suas origens. Também mestiço e oriundo da pequena classe média suburbana, não desfaz seu vínculo com os subúrbios cariocas e seus moradores, colocando-os, bem como alguns personagens negros, no centro de seus romances.

Ao oposto de Machado de Assis, que saído do morro do Livramento procuraria os bairros da classe média e abastada, este homem (Lima Barreto), nascido nas Laranjeiras, que se distinguiu nos estudos de Humanidades e nos concursos, que um dia sonhou tornar-se engenheiro, que no fim da vida ainda se gabava de saber geometria contra os que o acusavam de não saber escrever bem, procurou deliberadamente a feiúra e a tristeza dos bairros pobres, o avesso das aparências brancas e burguesas, o avesso de Botafogo e de Petrópolis. Não, talvez, por vocação natural, pois os seus mesmos desenganos sugerem que não fora de todo insensível ao feitiço daquelas aparências, nem pelo gosto literário das coisas pitorescas, mas por adoção e, ao fim, com desvelo confrangido. E também com muito de orgulho, daquela espécie de orgulho que o faria referir-se ao próprio desmazelo de hábitos e indumentária, dizendo que era essa a sua elegância e a sua pose. ${ }^{3}$

Em seu romance de 1909, Recordações do Escrivão Isaías Caminha, Lima Barreto apresenta um personagem que sofre com o preconceito de raça e de cor e, em seu último romance, Clara dos Anjos, concluído em 1922, ano de sua morte, Lima

\footnotetext{
${ }^{2}$ HOLANDA, Sergio Buarque. Prefácio. In: BARRETO, Lima. Clara dos Anjos. Rio de Janeiro: Ediouro, 1997. p. 4.

${ }^{3}$ Ibid. p. 5.
} 
Barreto aborda, pela primeira vez, o tema do preconceito e da pobreza vividos por uma mulher.

A jovem Clara não tem consciência de sua condição subalterna, de negra e pobre, e só consegue entender e situar-se na sociedade em que vive após ter sido seduzida e abandonada, grávida, por um jovem branco de extração burguesa.

A postura destes dois autores já revela algo sobre nossa sociedade que merece ser estudado: foi somente o estilo de Machado de Assis que o levou a não tratar do tema de forma aberta? O que fazia de Lima Barreto uma pessoa tão torturada, com crises de depressão e alcoolismo e, ao mesmo tempo tão crítico e partidário do "socialismo maximalista, tão emotivo nas raízes quanto penetrante na análise"? (Bosi, 1977, p. 356)

No século XX a situação manteve-se inalterada; a literatura brasileira não foi agraciada com o surgimento de nenhum (a) escritor (a) negro de renome. O máximo que produziu foi a tímida aparição de Carolina de Jesus e seu diário Quarto de Despejo, publicado em 1960. Porém, após a polêmica que seguiu a publicação do livro, Carolina - moradora de uma favela de São Paulo e catadora de papel - assim como seus outros escritos, caíram no esquecimento. Apesar de sua aparente irrelevância, Carolina continua sendo ponto único de referência quando é questionada a presença da figura feminina negra na literatura brasileira.

Vários anos de busca por outras escritoras negras brasileiras levaram, através de caminhos tortuosos e inesperados, aos nomes de quatro escritoras, praticamente desconhecidas, com obras publicadas no mercado editorial brasileiro, algumas com várias publicações no exterior: Maria Firmina dos Reis, Rute Guimarães, Geni Guimarães e Conceição Evaristo.

$\mathrm{O}$ achado injetou ânimo à pesquisa e acrescentou novos questionamentos: $\mathrm{O}$ que acontece com a nossa sociedade? A idéia do "homem cordial" está tão arraigada que 
não permite uma visão crítica dos problemas raciais ainda tão presentes no século XXI? O que esta ausência de interesse por escritores negros nos revela sobre a sociedade brasileira? Por que a mulher negra não teve voz? Por que, neste aspecto, a sociedade brasileira é tão diferente da sociedade norte-americana?

O estudo da literatura afro-americana, previamente realizado em minha pesquisa de mestrado, já sinalizava qual caminho deveria seguir para encontrar respostas.

Para entender a produção literária afro-americana, voltei-me para o estudo da história recente dos negros nos Estados Unidos da América, iniciando com a Guerra Civil (1861-1865) e culminando com o Movimento Pelos Direitos Civis e os acontecimentos que vieram em sua esteira nas décadas de 60 e 70 do século XX.

Aquele período foi bastante rico e motivador para a comunidade negra daquele país, com fortes reflexos ao redor do mundo, fomentando o surgimento de uma gama de escritoras voltadas para as questões de gênero e raça. Toni Morrison e Alice Walker são dois exemplos de autoras premiadas, com obras voltadas para o processo de construção da identidade cultural dos afro-descendentes norte-americanos, questão relevante no momento da escrita de seus romances mais relevantes.

Considerando que há uma estreita relação entre literatura, história e sociedade, que faz com que os textos sejam produtos de diferentes momentos históricos e de diferentes concepções das relações entre a literatura e a sociedade, um estudo da história dos negros no Brasil, portanto, revela-se como elemento importante na tentativa de compreender o status do negro não só na literatura, mas também em outros setores da sociedade brasileira.

Partindo deste princípio, o objetivo deste estudo é apresentar uma análise dos romances The Third Life of Grange Copeland, escrito por Alice Walker e publicado nos 
Estados Unidos em 1970, e Ponciá Vicêncio, escrito por Conceição Evaristo e publicado no Brasil em 2003, procurando estabelecer um paralelo entre ambos.

As duas obras têm em comum o fato de apresentar a temática da condição do negro nas sociedades norte-americana e brasileira, respectivamente, sob a ótica de mulheres afro-descendentes. As datas de publicação dos dois romances, no entanto, estão separadas por um período de tempo superior a trinta anos, fato este que requer um olhar mais atento e apurado, no sentido de apontar as condições de possibilidade para o seu surgimento e sua relevância para o momento de sua escritura.

Alice Walker teve seu romance publicado em 1970. A década anterior havia sido marcada por uma grande efervescência política e social nos Estados Unidos da América, com destaque para a Guerra do Vietnam - e seus desdobramentos - e para o Movimento Pelos Direitos Civis.

Deflagrado no sul do país, em 1955, com o boicote aos ônibus em Montgomery, Alabama, o Movimento cresceu vertiginosamente nos anos posteriores, sempre vencendo batalhas jurídicas que tinham como objetivo o banimento de leis segregacionistas. Seu líder mais proeminente, Martin Luther King, Jr., pregava a necessidade de se lutar de forma pacífica, não admitindo o uso da violência. O pastor norte-americano tinha como referência e modelo a ser seguido o líder pacifista indiano Mahatma Ghandi, principal personalidade da independência da Índia - nos anos 40 cujo movimento pacifista tinha como método principal a resistência passiva.

Assim, protestos, passeatas, marchas e discursos inflamados divulgados pela mídia mundo afora mostravam a violência e a repressão radical sempre partindo das autoridades norte-americanas, nunca dos manifestantes.

Mais conscientes da função política do movimento, os militantes do norte do país partiram para um ativismo violento. Ao contrário dos militantes do sul, que viviam 
a segregação racial regulamentada por leis (de jure), aqueles do norte tinham um alvo mais difícil de atacar: a segregação "de facto”, que, exatamente por ser um costume arraigado na cultura do país, gerava um sentimento de impotência e de revolta maior.

Moradores de uma região econômica, social e politicamente mais desenvolvida, tinham uma visão menos ingênua da amplitude das questões que afetavam suas vidas de maneira tão profunda. Jovens e radicais, muitos de seus líderes eram universitários ou recém-formados que se uniam aos demais afro-descendentes em torno dos mesmos objetivos.

Os militantes que mais se destacaram no norte do país foram Malcolm X (The Black Muslims/Nation of Islam), Stokely Carmichael (The Black Panther/SNCC Student Nonviolent Coordinating Committee, nome modificado em 1969 para Student National Coordinating Committee.) e H. Rap Brown (SNCC).

\begin{abstract}
Where the Civil Rights Movement had identified racism on the part of individuals as the major problem, Black Power advocates saw institutional racism as "the Enemy". The problem was not so much ignorant or bigoted people as corrupt institutions, including most of the social-political-economic system. Thus the problem with an incident like the attempted integration of the University of Alabama in 1956 was redefined. It didn't matter whether or not Black students were in attendance at the university: the problem was what that university, and by extension all universities, were teaching. ${ }^{4}$
\end{abstract}

\footnotetext{
${ }^{4}$ LINDSEY, Howard O. A history of black América. London: Bison Books, 1994. 160 p. p. 135.

"Enquanto o Movimento pelos Direitos Civis havia identificado o racismo por parte dos indivíduos como o maior problema, o Poder Negro via o racismo institucional como "O Inimigo". O problema não era tanto pessoas corruptas ou intolerantes, mas sim instituições corruptas, incluindo a maior parte do sistema sócio-político-econômico. Assim, o problema com um incidente como aquele da tentativa de integração na Universidade do Alabama em 1956 foi redefinido. Não importava se os alunos negros estavam freqüentando a universidade ou não: o problema era o que aquela universidade, e por extensão todas as universidades, estavam ensinando." (Tradução minha)
} 
Sob o comando de tais líderes o Movimento Pelos Direitos Civis enfrentava a violência através da violência. Assim, cidades como Nova Iorque, Los Angeles, Cleveland, Baltimore e São Francisco, dentre outras, passaram a vivenciar grandes motins, com incêndios, saques, mortos, feridos, e conseqüentes prejuízos de milhões de dólares.

Para além do acesso aos mesmos direitos oferecidos à população branca, ativistas como Malcolm X, por exemplo, pregavam a necessidade de os afro-americanos alcançarem posições de comando na política, economia, educação e demais áreas de interesse da população, para reverterem o processo de exploração da mão-de-obra negra e a conseqüente desigualdade econômica por ela gerada. Foram eles os criadores do Nationalist Ghetto Movement que exerceu considerável influência em diversos setores da sociedade norte-americana, atingindo também a academia e as artes.

Um dos reflexos da busca da dignidade racial foi o aumento da auto-estima dos afro-descendentes, fato este que fez com que passassem a sentir orgulho de suas origens e a utilizar a frase "Black is Beautiful" como símbolo deste sentimento nascente.

Estudiosos do assunto têm apresentado diferentes explicações para as origens e motivações do Movimento:

From the vantage point of the middle 1970s, the civil rights movement of the early 1960s can be seen as an attempt by blacks, with the partial and often reluctant support of liberal corporate groups, to end their isolation and be integrated more fully into the working class. Blacks fought for the rights earlier won by white working people, rights that characterize liberal capitalist society - public education, equal access to all public facilities, and the right to vote.

From the blacks' point of view these were simply demands for their human rights, which they have been denied because of their race. Radicals and most old leftists often saw these demands as 
revolutionary, in themselves a threat to the fabric of American capitalism. But within the logic of capitalist development these rights were a necessary part of integrating a rural, semifeudal work force into the capitalist market-place. Blacks fought for their rights in the South, and to a lesser extent in the North, primarily out of immediate need and for their own dignity. Radicals fought partly out of a sense of guilt and from a moral conviction in the rightness of equal rights, but also because they believed this activity to be inherently radicalizing. Liberal politicians and corporate groups supported these struggles in order more fully to rationalize and integrate the labor market and also in the hope of reducing overt social conflicts - and the embarrassment that open racial oppression in the United States caused American policymakers in international affairs, especially in the face of the emergence of the newly independent African nations. ${ }^{5}$

Qualquer que seja a explicação mais convincente - às quais voltaremos mais adiante neste estudo - parece claro que as circunstâncias históricas propiciaram a materialização de uma insatisfação generalizada que conseguiu mobilizar multidões e chamar atenção para uma situação que até então havia sido mantida sob controle.

\footnotetext{
${ }^{5}$ WEINSTEIN, James. Ambiguous legacy - the left in American politics. New York: New Viewpoints, 1975.

"Da posição privilegiada de meados dos anos setenta, o movimento pelos direitos civis do início dos anos sessenta pode ser visto como uma tentativa dos negros, com o apoio parcial e freqüentemente relutante de grupos empresariais, de acabar com o seu isolamento e ser plenamente integrados à classe trabalhadora. Os negros lutavam por direitos previamente conquistados pelos trabalhadores brancos, direitos que caracterizam a sociedade capitalista liberal - educação pública, acesso igualitário a todos os equipamentos públicos e o direito ao voto.

Do ponto de vista dos negros, eram apenas reivindicações de seus direitos humanos, que lhes haviam sido negados devido à sua raça. Os radicais e os esquerdistas mais antigos freqüentemente viam estas reivindicações como revolucionárias, uma ameaça à estrutura do capitalismo americano. Porém, pela lógica do desenvolvimento capitalista, aqueles direitos eram uma etapa necessária para a integração de uma força de trabalho rural, semi-feudal, ao mercado capitalista. Os negros lutavam por seus direitos no sul, e em escala menor no norte, basicamente movidos por necessidades imediatas e pela busca de sua dignidade. Os radicais lutavam em parte movidos por um sentimento de culpa e por uma convicção moral na justeza de direitos iguais, mas também porque acreditavam que sua luta era radical. Os políticos liberais e os grupos empresariais apoiavam as lutas principalmente para racionalizar e integrar o mercado de trabalho, mas também na esperança de reduzir os notórios conflitos sociais - e o embaraço que a opressão racial declarada nos Estados Unidos causava aos políticos americanos nas relações internacionais, especialmente em face do surgimento de nações africanas recém libertas. " (Tradução minha).
} 
Os avanços legais alcançados na época foram significativos: todas as leis segregacionistas foram abolidas, foi aprovada a Lei dos Direitos Civis (em 1964) e a Lei do Direito de Voto (em 1965). Esta última teve grande repercussão no país, mudando radicalmente a face política dos Estados Unidos. O Mississipi, por exemplo, o mais racista dos estados sulistas, teve um grande número de negros eleitos para cargos públicos, maior do que em qualquer outro estado do país.

Já os avanços sociais não foram mais eficazes em função da própria dificuldade dos envolvidos em se organizar. A esquerda norte-americana, por exemplo, não conseguiu chegar a um consenso acerca das reais necessidades da população negra, e os militantes negros estavam, na maioria das vezes, tão envolvidos com as necessidades imediatas da população que não conseguiam desenvolver um projeto político que determinasse os rumos que o movimento deveria seguir.

Sob esta perspectiva, embora seja de conhecimento geral que "o capitalismo inevitavelmente reintegrou os protestos dos pobres" (Hobsbawm, 1984, p. 404), as conquistas advindas da mobilização negra, embora longe do que seria considerado ideal, foram significativas, à medida que puderam, pelo menos, abrir caminhos para gerações futuras.

Os reflexos destes movimentos atingiram o mundo todo, em maior ou menor escala, mas no Brasil não foram tão marcantes, pois havia grandes diferenças entre os dois países, sendo a maior delas a crença na democracia racial.

Em primeiro lugar, os afro-americanos destacaram-se pela sua capacidade de mobilização (exercitada anteriormente pelos operários da indústria daquele país), algo ainda inimaginável para os afro-brasileiros, pois a situação de exclusão em que a imensa maioria se encontrava, sem acesso principalmente à educação, os impedia não só de 
compreender sua real condição em nossa sociedade, como também os levava a aceitar sua condição pacificamente.

Em segundo lugar, havia a situação política do país que, após experimentar um breve período de grande mobilização das massas operárias no governo de João Goulart, vivia então sob a opressão e a violência do regime ditatorial instaurado pelo Golpe Militar de 1964.

Em terceiro lugar, os afro-americanos tinham um alvo concreto contra o qual lutar: a existência das leis segregacionistas, algo que nunca existiu no Brasil e que, portanto, dificultava uma tomada de posição.

Essa ausência de leis segregacionistas também pode ser considerada como uma justificativa importante para o pequeno número de organizações voltadas aos interesses da causa negra durante quase todo o século XX.

Neste período, houve a criação da Frente Negra Brasileira, em 1931, a Associação de Negros Brasileiros, em 1945, e o Movimento Unificado Contra a Discriminação Racial (MNUCAR), depois Movimento Negro Unificado (MNU), em 1978.

Foi somente nas duas últimas décadas do século passado e no início deste que a sociedade brasileira viu surgir um grande número de associações e movimentos voltados para a população negra. Em sua grande maioria são organizações nãogovernamentais que realizam um trabalho de cunho social, amparando e orientando a população negra em questões legais e de saúde, e promovendo cursos de alfabetização de adultos e profissionalizantes com o objetivo de inseri-la no mercado de trabalho.

Vários são os motivos que levaram à recente preocupação com esta esquecida camada da população brasileira, a maioria deles vinculados a questões políticoeconômicas. 
O primeiro deles refere-se à nossa condição de ex-colonia, cujas referências culturais importadas aplicam-se "num espaço com travejamento sociológico diferente, diverso mas não alheio [...]" (Schwarz, 1999, p. 95), onde os avanços do primeiro mundo demoram a chegar e, salvo pouquíssimas exceções, quando o fazem são adaptados à realidade nacional.

Como país periférico, com desigualdades sociais e econômicas gritantes, as influências estrangeiras historicamente atingem o Brasil com muitos anos de atraso. Portanto, não se configura como surpresa o fato de somente agora, mais de um século depois de tal preocupação ter permeado ações nos Estados Unidos da América, a sociedade brasileira ter se sensibilizado com a causa negra.

O segundo motivo está ligado às questões de ordem social. Séculos de atraso e opressão geraram a formação de bolsões de pobreza e violência na periferia das grandes cidades. Os moradores das favelas, hoje convivendo diariamente com a guerra entre os traficantes de drogas e a ineficiência da polícia, muitas vezes corrompida, estão se organizando. Em um claro exemplo do "mal que acontece para o bem" encontram amparo e proteção nos líderes do tráfico, dispostos a matar para sobreviver em uma sociedade que os privou de toda sorte de direitos ao mesmo tempo em que os incita, através da mídia - principalmente a televisão - a possuir bens de consumo acessíveis apenas para a camada dominante. Implícita na programação das emissoras de televisão, bem como nas propagandas veiculadas, está a mensagem de que todos, indistintamente, podem e devem possuir as mercadorias anunciadas.

Mantida à margem e ao mesmo tempo submetida paulatinamente ao fetiche da mercadoria, é claramente uma ameaça ao sistema, instaurando a insegurança e o medo, que exigem uma tomada de posição para impedir o seu crescente poder. 
Em terceiro lugar, surgem os efeitos de uma mudança na condição sócioeconômica de uma pequena parcela da população negra. Os últimos anos têm presenciado a formação de uma classe média constituída por afro-descendentes que conseguiram uma ascensão social, principalmente através da educação, seguida de perto por outros setores econômicos, e têm esboçado uma reação ao sistema. Parte deste grupo tem demonstrado interesse em afirmar sua identidade através de ações que valorizem suas origens - como descendentes de uma cultura rica em tradições - e também através de ações de apoio às camadas mais carentes.

Esta nova conformação gera a necessidade de mudanças e adaptações e, por isso, remete automaticamente às questões econômicas: o capitalismo passa por uma crise sistêmica e a formação dessa nova classe média proporcionou o surgimento de um novo nicho mercadológico, com potencial para gerar grandes lucros. Originam-se desta compreensão os produtos de beleza para peles e cabelos negros, bem como roupas, calçados, acessórios e as demais mercadorias que transmitem imagens de status e aceitação. Como o capitalismo se configura como um poderoso mecanismo de leitura do desejo, tais produtos aparecem com força na mídia escrita e falada, vinculados a belos modelos que realçam o diferencial étnico e que têm o poder de atrair essa nova legião de consumidores. Portanto, esta tendência de valorização do afro-descendente é, no mínimo, interessante ao sistema. ${ }^{6}$

O romance Ponciá Vicêncio, segundo a ser analisado, insere-se neste contexto da História brasileira. Produzido por uma ótica diversa daquela reinante, abre espaço para interessantes reflexões acerca da sociedade e da arte no Brasil pós-moderno. A sua comparação com a literatura produzida por Alice Walker deverá propiciar um melhor

\footnotetext{
${ }^{6}$ A título de comparação, é interessante lembrar que a mesma reação do sistema econômico ocorre com relação ao público homossexual, que tem conquistado cada vez mais visibilidade através de suas manifestações públicas exigindo aceitação de sua condição e conseqüente igualdade de direitos. $\mathrm{O}$ mercado também já os percebeu como consumidores potenciais e tem investido pesadamente em sua conquista.
} 
entendimento das tensas relações entre raça e sociedade, presentes tanto no centro quanto na periferia, e levantar questões acerca da pertinência e validade da literatura em um mundo predominantemente capitalista e globalizado cujo mecanismo de diferenciação se dá através das imagens.

\section{THE THIRD LIFE OF GRANGE COPELAND}

On Monday, suffering from a hangover and the aftereffects of a violent quarrel with his wife the night before, Grange was morose, sullen, reserved, deeply in pain under the hot early morning sun. Margaret was tense and hard, exceedingly nervous. Brownfield moved about the house like a mouse. On Tuesday, Grange was merely quiet. His wife and son began to relax. On Wednesday, as the day stretched out and the cotton rows stretched out even longer, Grange muttered and sighed. He sat outside in the night air longer before going to bed; he would speak of moving away, of going North. He might even try to figure out how much he owed the man who owned the fields. The man who drove the truck and who owned the shack they occupied. But these activities depressed him, and he said things on Wednesday 
nights that made his wife cry. By Thursday Grange's gloominess reached its peak and he grimaced respectfully, with veiled eyes, at the jokes told by the man who drove the truck. On Thursdays nights he stalked the house from room to room and pulled himself up and swung from the rafters of the porch. Brownfield could hear his joints creaking against the sounds of the porch, for the whole porch shook when his father swung. By Friday Grange was so stupefied with the work and the sun he wanted nothing but rest the next two days before it started all over again. On Saturday afternoon Grange shaved, bathed, put on clean overalls and a shirt and took the wagon into town to buy groceries. While he was away his wife washed and straightened her hair. She dressed up and sat, all shining and pretty, in the open door, hoping anxiously for visitors who never came.

Brownfield too was washed and cleanly dressed. He played contentedly in the silent woods and in the clearing. Late Saturday night Grange would come home lurching drunk, threatening to kill his wife and Brownfield, stumbling and shooting off his shotgun. He threatened Margaret and she ran and hid in the woods with Brownfield huddled at her feet. Then Grange would roll out the door and into the yard, crying like a child in big wrenching sobs and rubbing his whole head in the dirt. He would lie there until Sunday morning, when the chickens pecked around him, and the dog sniffed at him and neither his wife nor Brownfield went near him. Brownfield played instead on the other side of the house. Steady on his feet but still ashen by noon, Grange would make his way across the pasture and through the woods, headlong, like a blind man, to the Baptist church, where his voice above all the others was raised in song and prayer. Margaret would be there too, Brownfield asleep on the bench beside her. Back home again after church Grange and Margaret would begin a supper quarrel which launched them into another week just about like the one before. $^{7}$

\footnotetext{
${ }^{7}$ WALKER, Alice. The third life of Grange Copeland. New York: Harcourt Books, 2003. 318 p. P. 13 $-14$.

"Na segunda-feira, sofrendo com uma ressaca e os reflexos de uma briga violenta com sua mulher na noite anterior, Grange ficava taciturno, rabugento, reservado, com uma dor profunda sob o sol quente da manhã. Margaret ficava tensa, excessivamente nervosa. Brownfield movia-se pela casa como um rato. Na terça-feira, Grange ficava simplesmente calado. Sua mulher e filho começavam a relaxar. Na quarta-feira, à medida que o dia se prolongava e as fileiras de algodão se prolongavam mais ainda, Grange resmungava e suspirava; à noite, ele ficava sentado no quintal por muito tempo antes de ir se deitar; falava em mudar,
} 
O recorte acima ilustra de maneira sucinta e crua a rotina de Grange Copeland, personagem principal do romance The third life of Grange Copeland, escrito pela escritora afro-americana Alice Walker entre os anos de 1968 e 1969.

The third life of Grange Copeland é o primeiro romance escrito pela autora que nos expõe, através da história de Grange, as vidas de três gerações da família Copeland. Essa exposição cobre um período de sessenta anos na vida de uma família negra que vive no interior da Geórgia, trabalhando como meeiros em uma fazenda.

Grange Copeland - o chefe da família - tem um relacionamento agressivo e desrespeitoso com sua mulher, Margaret, que tem reflexos diretos na educação de seu filho - Brownfield. Em sua infância e adolescência ele é negligenciado, a princípio, pelo pai e depois também pela mãe. A agressividade de Grange está diretamente relacionada com a sua condição social, que não lhe permite suprir as necessidades básicas de sua família. Consciente de que é oprimido e explorado, realizando um trabalho penoso e cansativo na lavoura que, ao final do ano, lhe rende roupas velhas, um pouco de comida

em ir para o norte. Ele até tentava calcular quanto ele devia para o proprietário das terras. O homem que dirigia o caminhão e que era dono da tapera em que eles moravam. Mas aquelas atividades o deprimiam, e ele dizia coisas às quartas-feiras à noite que faziam sua mulher chorar. Na quinta-feira a tristeza de Grange atingia o ápice e ele reagia respeitosamente, com olhos enevoados, às piadas contadas pelo homem que dirigia o caminhão. Às quintas-feiras à noite ele inspecionava a casa cômodo por cômodo, parava e se balançava nas vigas do alpendre. Brownfield podia ouvir suas juntas rangendo em contraste com os sons do alpendre, pois o alpendre inteiro estalava quando seu pai se balançava. Na sexta-feira Grange estava tão entorpecido com o trabalho e o sol que ele não queria nada exceto descansar nos próximos dois dias antes de tudo começar novamente. No sábado à tarde Grange barbeava-se, tomava banho, vestia um macacão e uma camisa limpos e pegava a carroça para ir à cidade comprar mantimentos. Enquanto ele estava fora sua mulher lavava e alisava o cabelo. Ela se vestia e sentava à porta, resplandecente e bonita, esperando ansiosamente por visitas que nunca vinham. Brownfield também era banhado e vestido com roupas limpas. Ele brincava alegremente na mata e na clareira. Tarde da noite Grange voltava para casa completamente embriagado, ameaçando matar a mulher e Brownfield, cambaleando e dando tiros. Ele ameaçava Margaret e ela corria e se escondia na mata com Brownfield enroscado em seus pés. Então Grange rolava para o quintal, chorando alto como uma criança e esfregando sua cabeça na terra. Ele ficava deitado lá até a manhã de domingo, quando as galinhas ciscavam em volta dele e o cachorro o cheirava e nem sua esposa nem Brownfield chegavam perto. Brownfield, ao contrário, brincava do outro lado da casa. Ao meio-dia, em pé, mas ainda pálido, Grange atravessava o pasto e a mata precipitadamente em direção à igreja Batista, onde a sua voz sobressaia as outras em música e oração. Margaret estava lá também, Brownfield dormindo no banco ao lado dela. Novamente em casa, depois da igreja, Grange e Margaret começavam uma grande briga que os lançava a outra semana igual à anterior." (Tradução minha). 
e uma dívida perene junto ao proprietário da fazenda, incapaz de amar e proteger sua família, pois se sente preso àquela vida por causa deles, Grange não consegue sentir-se um homem de verdade. Para agravar a situação, não é capaz de proteger sua mulher contra o assédio do homem branco, Shipley, muito menos de proporcionar uma vida melhor para seu filho.

Com sua auto-estima atingida da pior forma possível, Grange encontra refúgio na bebida e nos braços de Josie, sua amante e dona do bordel de sua cidadezinha, e direciona para Margaret e Brownfield a violência com que é tratado pela sociedade.

Seu comportamento atinge Margaret profundamente, pois, à medida que seus sonhos vão sendo destruídos, ela também passa a se autodestruir através da bebida e da prostituição, que a leva a ter um filho bastardo.

Brownfield, por sua vez, personifica todas as mazelas de uma criança criada sem amor, carinho ou atenção, carente da figura dos pais e com uma auto-estima absolutamente frágil.

Neste contexto, Grange foge para o norte do país em busca de uma vida melhor, Margaret mata seu filho bastardo e depois se suicida, deixando Brownfield completamente só aos dezesseis anos de idade.

Abandonado, Browfield resolve seguir os passos do pai e ir para o norte também. Porém, muito jovem e inexperiente, acaba indo parar no bordel de Josie onde transforma-se em seu empregado e amante. Lá conhece Mem, uma professora recémformada que é sobrinha de Josie. Eles se apaixonam, se casam e começam a repetir o mesmo processo de desrespeito e destruição que marcou a vida de Margaret e Grange. Ao contrário de Margaret, porém, Mem empenha-se ao extremo para que a vida da família, agora com três filhas (Daphne, Ornette e Ruth) melhore e se estabilize. 
Brownfield, no entanto, volta para os braços de Josie, onde consegue algum conforto até a volta de seu pai, quando perde também o amor dela para Grange, o homem que antes o havia abandonado.

A deterioração do relacionamento de Brownfield e Mem é uma réplica daquela que ocorreu com seus pais, com o agravante de Brownfield chegar ao extremo de matar seu filho recém-nascido por ele ser albino e ter muita semelhança com Grange. Ele acredita estar se vingando de seu pai dessa maneira.

Por um breve período Mem consegue, após ameaçar Brownfield com uma arma em um momento de fraqueza dele, dominá-lo e mudar para a cidade com a família, onde experimentam certo progresso material e certa paz familiar. $O$ sentimento de inferioridade, sempre presente em função da cultura de Mem, e a humilhação sentida ao constatar que Mem havia conseguido em tão pouco tempo muito mais do que ele conseguira para sua família, transformou Brownfield em uma espécie de fera enjaulada que aguardava o momento certo para o ataque. Sua vingança ocorre após engravidar Mem, intencionalmente, por duas vezes consecutivas. Ela sofre dois abortos espontâneos e, enfraquecida e doente, é obrigada a parar de trabalhar e passar o comando da família novamente para as mãos de Brownfield, que leva todos de volta para a lavoura, vivendo em condições mais precárias do que aquelas em que viviam antes de ir para a cidade.

A vida conjugal do casal encerra-se com o assassinato de Mem por Brownfield com um tiro no rosto disparado a queima-roupa na frente das filhas - em uma véspera de Natal.

Assim como seu pai fizera antes com ele, Brownfield deixa suas três filhas órfãs e desamparadas. Com a sua prisão, suas duas filhas mais velhas são levadas para o norte do país pelo avô materno, e Ruth - a caçula - passa a viver com Grange, que havia 
voltado para o sul e casado com Josie. Ruth lhe dá nova vida, motivando-o a fazer por ela tudo que não havia feito por seu filho. Brownfield, porém, absolutamente brutalizado e degradado, junta-se a Josie, agora negligenciada por Grange em prol de Ruth, para tomá-la do avô. Ao ser libertado, Brownfield consegue a custódia de Ruth e é deliberadamente assassinado por Grange, que acredita ser esta a única possibilidade de sobrevivência para a neta. Grange é então assassinado por policiais em sua casa. Encerra-se, assim, a saga da família Copeland.

Ao apresentar as vidas das pessoas que compõem a família Copeland, Alice Walker articula uma série de relações que visam investigar e explicar os motivos que levam a grande maioria dos afro-descendentes norte-americanos a se auto-destruir e a destruir aqueles que os cercam.

Para fundamentar sua compreensão desta realidade a autora constrói uma narrativa assentada em dois pilares fundamentais. O primeiro deles é a teoria do psiquiatra Frantz Fanon sobre as relações colonizador/colonizado, amplamente difundida nos anos sessenta do século $\mathrm{XX}$ - época em que o romance foi escrito. $\mathrm{O}$ segundo pilar são as relações entre o homem e a História, como definidas por Karl Marx:

Os homens fazem a sua própria história, mas não a fazem segundo a sua livre vontade; não a fazem sob circunstâncias de sua escolha, mas sob aquelas circunstâncias com que se defrontam diretamente, legadas e transmitidas pelo passado. ${ }^{8}$

Grange Copeland, ao longo da narrativa, tenta fazer a sua História, mas sofre o tempo todo o impacto do movimento da história que exerce influência direta em seu

\footnotetext{
${ }^{8}$ MARX, Karl. O dezoito brumário de Louis Bonaparte. São Paulo: Centauro, 2003. p. 15. 149 p.
} 
comportamento e, conseqüentemente, em sua vida. Membro de uma sociedade cuja ideologia opressora está profundamente assentada no sistema capitalista, Grange impõese a difícil tarefa de reescrever sua história e, simbolicamente, a de seu povo, através da luta contra valores sociais, morais e culturais moldados pelo culto norte-americano à figura do "vencedor".

É natural, dentro de uma sociedade assim estabelecida, o surgimento de situações de conflito que impulsionem seus membros no sentido de promover mudanças que beneficiem ora a elite ora a população marginalizada. No último caso, porém, com uma freqüência muito menor e como conseqüência do jogo de interesses que buscam sempre favorecer a classe dominante. Assim é feito o movimento da História.

Partindo deste princípio, Alice Walker apresenta uma família negra como representante do todo social desta população; pessoas pobres, não consumidoras, tratadas como não gente, ou como pessoas de segunda categoria, pela cultura do consumo.

\subsection{A MISÉRIA DOS COPELAND E AS TEORIAS DE}

\section{FRANTZ FANON}

A narrativa tem início com uma apresentação da família Copeland mergulhada em uma situação de extrema pobreza e desesperança. Esta "primeira vida" de Grange 
Copeland é apresentada sob a ótica do filho do casal - Brownfield - e compreende o período relativo à sua infância e adolescência.

É através do seu olhar que o leitor toma conhecimento da vida do casal: das longas horas de trabalho árduo, das esperanças se esvaindo e cedendo lugar à revolta e ao sentimento de impotência, das traições mútuas, do abandono e negligência com que sempre trataram o filho, da fuga de Grange Copeland e da morte de Margaret e de seu filho bastardo. É através dele, também, que a relação de Grange com seu patrão é apresentada.

[...] For when the truck came his father's face froze into an unnaturally bland mask, curious and unsettling to see. It was as if his father became a stone or robot. A grim stillness settled over his eyes and he became an object, a cipher, something that moved in tense jerk if it moved at all...Some of the workers laughed and joked with the man who drove the truck, but they looked at his shoes and at his pants legs or at his hands, never into his eyes, and their looks were a combination of small sly smiles and cowed, embarrassed desperation.

[...] While he stared at the hair one of the workers - not his father who was standing beside him as if he didn't know he was there - said to him softly, "Say 'Yessir' to Mr. Shipley," and Brownfield looked up before he said anything and scanned his father's face. The mask was as tight and still as if his father had coated himself with wax. And Brownfield smelled for the first time an odor of sweat, fear and

\footnotetext{
${ }^{9}$ WALKER, Alice. The third life of Grange Copeland. New York: Harcourt Books, 2003. 318 p. p. 8. “[...] Pois quando o caminhão chegava o rosto de seu pai congelava-se em uma máscara artificialmente mansa, curiosa e perturbadora. Era como se seu pai se transformasse em uma pedra, um robô. Uma calma medonha instalava-se em seus olhos e ele se transformava em um objeto, em nada, alguma coisa que se movia em um trejeito tenso, se de algum modo se movesse... Alguns trabalhadores riam e brincavam com o homem que dirigia o caminhão, mas eles olhavam para os sapatos e calças dele ou para suas mãos, mas nunca nos seus olhos, e os seus olhares eram uma combinação de pequenos sorrisos dissimulados e um desespero assustador, desconcertante." (Tradução minha)
} 
something indefinite. Something smothered and tense (which was of his father and of the other workers and not of mint) that came from his father's body. His father said nothing. Brownfield, trembling said "Yessir", filled with terror of this man who could, by his presence alone, turn his father into something that might as well have been a pebble or a post or a piece of dirt, except for the sharp odor of something whose source was forcibly contained in flesh. ${ }^{10}$

Essa relação ambígua, movida pelo ressentimento e pelo temor, é uma réplica das relações colonizador/colonizado descritas por Fanon em seu livro The wretched of the earth.

[...] Mas todas as vezes que se trata de valores ocidentais produz-se, no colonizado, uma espécie de retesamento, de tetania muscular... No contexto colonial, o colonizador só dá por findo seu trabalho de desancamento do colonizado quando este último reconhece em voz alta e inteligível a supremacia dos valores brancos. ${ }^{11}$

[...] Se, com efeito, minha vida tem o mesmo peso que a do colono, seu olhar não me fulmina, não me imobiliza mais, sua voz já não me petrifica.. $^{12}$

\footnotetext{
${ }^{10}$ Ibid. p. 10. "Enquanto ele olhava fixamente para o cabelo, um dos trabalhadores - não seu pai que estava em pé ao seu lado como se não soubesse que estava lá - disse-lhe suavemente, "Diga, "Sim, sinhô" para o Senhor Shipley," e Brownfield ergueu os olhos antes de dizer qualquer coisa e examinou minuciosamente o rosto de seu pai. A máscara estava tão rígida e imóvel como se seu pai tivesse se revestido com cera. E Brownfield sentiu pela primeira vez um cheiro de suor, medo e alguma coisa indefinida. Algo sufocado e tenso (que exalava de seu pai e dos outros trabalhadores e não de hortelã) que vinha do corpo de seu pai. O pai dele não disse nada. Brownfield, trêmulo, disse "Sim, sinhô", cheio de pavor daquele homem que podia, com sua presença apenas, transformar seu pai em algo que poderia ser igualmente um cascalho, um poste ou um pedaço de terra, exceto pelo odor amargo e penetrante de alguma coisa cuja origem estava forçosamente contida na própria carne.” (Tradução minha)

${ }^{11}$ FANON, Frantz. Os condenados da terra. Rio de Janeiro: Civilização Brasileira, 1979. P. 32

${ }^{12}$ Ibid. p. 34.
} 
Transpostas dos países africanos colonizados por europeus para a experiência negra no interior dos Estados Unidos, as teorias de Fanon são exemplificadas pelo comportamento de Grange: uma revolta contida que se torna visível através de sua perturbação e consequiente imobilização diante do patrão (colonizador) e que vai gerar em seu filho (colonizado) um temor muito grande daquele homem que consegue, apenas com sua presença, afetar seu pai (colonizado) tão profundamente; uma sensação de impotência e de inferioridade que é a causa de sua frágil auto-estima e de sua apatia diante das dificuldades que o cercam; uma insegurança muito grande com relação à sua masculinidade e ao seu suposto papel de provedor das necessidades de sua família, guardião da integridade física e psicológica dos seus e modelo a ser seguido e imitado pelo filho; e, por fim, a transferência para a sua família, únicas pessoas sobre as quais pode exercer algum poder, de toda a violência com que é tratado.

Mundo compartimentado, maniqueísta, imóvel [...] Mundo seguro de sí, que esmaga com suas pedras os lombos esfolados pelo chicote. Eis o mundo colonial. O indígena é um ser encurralado, o apartheid é apenas uma modalidade da compartimentação do mundo colonial. A primeira coisa que o indígena aprende é a ficar no seu lugar, não ultrapassar os limites. Por isso é que os sonhos do indígena são sonhos musculares, sonhos de ação, sonhos agressivos.

Esta agressividade sedimentada nos músculos, vai o colonizado manifestá-la primeiramente contra os seus. É o período em que os negros brigam entre si e os policiais, os juízes de instrução exasperamse ante a assombrosa criminalidade norte - africana. ${ }^{13}$

Traçando um paralelo entre o sentimento de impotência e de inadequação de Grange e aquele vivenciado pelo colonizado africano, verifica-se que a origem dos

\footnotetext{
${ }^{13}$ Ibid. p. 39.
} 
problemas de ambos está no tipo de sociedade na qual estão inseridos e que promove diferentes formas de opressão.

O colonizado africano foi submetido a valores sociais e culturais importados, trazidos da Europa pelo homem branco, capitalista e, via de regra, oriundo da camada burguesa de seu país de origem. Grange Copeland, um estranho em sua própria terra, também tem que lidar com valores sociais e culturais produzidos por uma sociedade cuja classe dominante também é branca, capitalista, burguesa e que se orgulha de sua origem igualmente européia.

Inserido neste contexto, Grange personifica as contradições que os homens de sua cor e classe social - paupérrimos - vivem ao tentar seguir os padrões estabelecidos pela cultura dominante. Ao seu fracasso em todas as esferas, contrapõe-se a figura bem sucedida do homem branco, "chefe" da família nuclear, "provedor" e "guardião" dos seus, "modelo" a ser seguido e imitado pelos filhos. Enfim, um "vencedor" que se empenha em legar valores morais e sociais, bem como a independência financeira, aos seus descendentes.

Tal modelo de sucesso foi histórica e culturalmente construído pela burguesia branca européia, que via a constituição da família nuclear e monogâmica - "guardiã " dos valores morais, religiosos e éticos, "célula mater" da sociedade - como a melhor forma de garantir a manutenção dos bens e privilégios alcançados, direta ou indiretamente, através do capital e da exploração da mão de obra barata.

Representante de um grupo étnico e social que se define em relação aos brancos, Grange, compreensivelmente, sente toda a força destes conceitos e valores a lhe oprimir, visto que não dispõe dos meios que lhe permitiriam igualar-se a seu modelo.

Aturdido e infeliz, ele consegue vislumbrar uma única saída: fugir. Fugir do trabalho, da família, de sua cidade... 
Ao fugir para o norte do país e abandonar sua família, Grange dá início à sua "segunda vida", agora em Nova Iorque, onde aprenderá mais sobre a miséria humana e sobre a sua condição subalterna na sociedade em que vive. Simbolicamente, a autora apresenta esta jornada como um processo necessário ao auto-conhecimento, à descoberta do amor-próprio e à conscientização de que o indivíduo deve assumir responsabilidade por sua própria vida.

Esta jornada, de importância capital para a trama, é negada a Brownfield, cujo último momento ao lado do pai, além de ser absolutamente dramático, irá definir seu comportamento enquanto homem, companheiro e pai.

Brownfield pretended to be asleep, though his heart was pounding so loudly he was sure his father would hear it. He saw Grange bend over him to inspect his head and face. He saw him reach down to touch him. He saw his hand stop, just before it reached his cheek. Brownfield was crying silently and wanted his father to touch the tears. He moved toward his father's hand, as if moving unconsciously in his sleep. He saw his father's hand draw back, without touching him. He saw him turn sharply and leave the room. He heard him leave the house. And he knew, even before he realized his father would never be back, that he hated him for everything and always would. And he most hated him because even in private and in the dark and with Brownfield presumably asleep, Grange could not bear to touch his son with his hand. ${ }^{14}$

\footnotetext{
${ }^{14}$ WALKER, Alice. The third life of Grange Copeland. New York: Harcourt Books, 2003. 318 p. P. 25 $-26$.

"Brownfield fingia estar dormindo, embora seu coração estivesse batendo tão forte que ele tinha certeza que seu pai poderia ouvi-lo. Ele viu Grange debruçar-se sobre ele para observar sua cabeça e seu rosto. Ele o viu abaixar-se para tocá-lo. Ele viu a sua mão parar antes de tocar sua face. Brownfield estava chorando silenciosamente e queria que seu pai sentisse suas lágrimas. Ele se moveu em direção à mão de seu pai, como se estivesse se mexendo inconscientemente durante o sono. Ele viu a mão de seu pai recuar, sem tocá-lo. Ele o viu virar-se bruscamente e sair do quarto. Ele o ouviu deixar a casa. E ele sabia, mesmo antes de compreender que seu pai jamais voltaria, que ele o odiava por tudo e sempre odiaria. E ele o odiava mais ainda porque mesmo privadamente e no escuro e com Brownfield supostamente dormindo, Grange não suportava tocar seu filho. (Tradução minha).
} 
O modelo de homem a ser seguido era este: agressivo, violento, negligente e insensível. Assim, enquanto Grange vive sua segunda vida, a degradação física, moral e espiritual de Brownfield, o conseqüente fracasso de seu casamento com Mem e o abandono de suas três filhas não causam surpresa. Embora não desejasse trilhar o mesmo caminho de seu pai, sua personalidade, mais fraca ainda que a de Grange, já estava formada. Sua carência de modelos positivos era maior ainda que a de seus pais e a consciência de sua impotência simplesmente o imobilizava, impedindo-o de vislumbrar uma saída, desistindo até mesmo de ir para o norte, como Grange fizera.

A família de Brownfield não consegue ficar imune à sua derrocada. Mem é assassinada por ele, Daphne (a filha mais velha) enlouquece e Ornette (a filha do meio) torna-se prostituta. Somente Ruth, a caçula, consegue ter uma infância e juventude aparentemente normais em função de sua convivência com Grange, agora em sua terceira vida, modificado e convencido de que pode redimir-se dos erros do passado fazendo pela neta tudo aquilo que não fez pelo filho.

Sob uma perspectiva psicológica, a narrativa mostra-se coerente. O próprio crescimento moral e espiritual de Grange ocorre absolutamente dentro das teorias preconizadas por Fanon: a morte do opressor é condição essencial para a libertação psicológica do oprimido.

Ao presenciar, em Nova Iorque, o afogamento de uma mulher branca e grávida que recusou sua ajuda, negando-se a tocar a mão de um "nigger", Grange sente-se livre da opressão e do medo que a simples presença do homem branco inspirava. $O$ simbolismo do acontecimento é evidente: Grange não é o responsável direto pela morte da mulher; ao contrário, até tenta salvá-la. Porém, a cor da sua pele bem como o fato de estar grávida faz com que Grange sinta não só que matou a causa de todos os seus tormentos, mas também os descendentes de seus algozes. 
O quadro apresentado por Fanon fica, assim, completo e é devidamente explicado pela conversa que Grange tem, anos mais tarde, com Ruth acerca das relações entre negros e brancos:

The white folks hated me and I hated myself until I started hating them in return and loving myself. Then I tried just loving me, and then you, and ignoring them much as I could. You're special to me because you're a part of me I didn't even used to want. I want you to go on a long time, have a heap of children. Let them know what you made me see, that it ain't no use in seeing at all, if you don't see straight. ${ }^{15}$

O seu relato de como conseguiu libertar-se do fardo que carregava remete diretamente à seguinte afirmação de Fanon:

[...] A descolonização jamais passa despercebida porque atinge o ser, modifica fundamentalmente o ser, transforma espectadores sobrecarregados de inessencialidade em atores privilegiados, colhidos de modo quase grandioso pela roda-viva da história. Introduz no ser um ritmo próprio, transmitido por homens novos, uma nova linguagem, uma nova humanidade. A descolonização é, em verdade, criação de homens novos. Mas esta criação não recebe sua legitimidade de nenhum poder sobrenatural; a "coisa" colonizada se faz no processo mesmo pelo qual se liberta. ${ }^{16}$

\footnotetext{
${ }^{15}$ Ibid., p. 252. "A gente branca me odiava e eu me odiava também até que comecei a odiá-los e a me amar. Então eu tentei apenas me amar, e depois você, e ignorá-los o quanto eu pudesse. Você é especial para mim porque é uma parte de mim que eu nem mesmo queria. Eu quero que você viva muito tempo, tenha um monte de filhos. Deixe-os saber aquilo que você me fez compreender, que não há utilidade alguma em enxergar, se você não enxerga corretamente." (Tradução minha).

${ }^{16}$ FANON, Frantz. Os condenados da terra. Rio de Janeiro: Civilização Brasileira, 1979. P. 26-27.
} 
Uma vez alcançada a liberdade psicológica, faz-se necessário percorrer o caminho que leva à igualdade material e social.

Grange e Brownfield Copeland são a personificação do negro norte-americano do início do século passado: indivíduos que vivem à margem de uma sociedade capitalista, hegemônica e racista. São massacrados por um sistema que, através de um discurso culturalmente construído, estabelece padrões de comportamento, valores e modelos sociais inalcançáveis por pessoas que são duplamente inferiores na escala social: negros e pobres. O sistema revela-se particularmente cruel à medida que estabelece mecanismos que perpetuam a condição dos menos favorecidos, enfraquecendo-os moral e psicologicamente através da impossibilidade de alcançar o sucesso material por ele preconizado.

Fruto desta sociedade, Grange tenta enfrentá-la com as armas que conhece, ou melhor, com aquelas que lhe foram apresentadas como fundamentais para ser um "vencedor".

Para tanto, a condição primeira é o acúmulo de capital para a aquisição de bens materiais. Grange atinge esta meta voltando para o sul com algum dinheiro e casando-se com Josie. Com o casamento, consegue convencê-la a ajudá-lo a comprar terras onde possa morar e exercer seu ofício de agricultor, cultivando e vendendo seus produtos de modo a ser economicamente independente. Esta nova forma de viver o afasta do convívio forçado com o homem branco e lhe proporciona independência financeira.

Ter uma casa mais confortável, se comparada com o casebre no qual vivia com Margaret e Brownfield, comprar um carro, oferecer alimentos e vestimenta adequados para si, Josie e para a neta, e conseguir mantê-la em uma escola foram conseqüências naturais da sua ascensão financeira. Seu novo "status social" lhe proporcionou tranqüilidade e liberdade para dedicar-se à educação moral e formal de Ruth, sua neta. 
Os reflexos desta nova posição na escala social atingiram diretamente a vida de Ruth. Ela deixa de ser uma menina paupérrima e vítima constante da violência doméstica praticada por seu pai e passa a ter um "lar", ao lado do avô e sua nova esposa. Ao crescer dentro de uma estabilidade econômica que lhe permitia ter certo conforto material, freqüentar a escola e relacionar-se com as demais pessoas de sua idade em situação de igualdade financeira, transforma-se em uma jovem psicologicamente mais estruturada que seus pais e avós, com uma forte auto-estima e consciência étnica.

Em sua análise do romance, Thadious $M$. Davis discute a questão da importância das relações familiares, apresentadas e defendidas por Alice Walker como fontes de segurança emocional. Na visão da autora, indivíduos emocionalmente seguros serão fortes o suficiente para se definirem como membros de um grupo étnico e social, fato este que lhes pavimentará o caminho do crescimento espiritual, social e político:

[...] three generations of Copelands converge to create Ruth's identity, and three generations form the stages or lives of the patriarch and title character, Grange Copeland. When any one member of the Copeland family or of a particular social generation of blacks (from 1920 to 1960) ignores the dynamics of family structures or forgets the historical perspective that the structures are maintained through necessity and love, he or she loses the capacity for primary identifications with race, family and community, and loses as well the major basis for defining one's self and one's humanity. The most detailed illustration presented in the novel is Brownfield, the son of Grange and a member of the middle generation in the work. ${ }^{17}$

17 DAVIS, M. D. Walker's celebration of self in southern generations. In: BLOOM, H. (ed.) Alice Walker. New York: Chelsea House Publisher, 1989.245 p. P. 33. "Três gerações de Copelands convergem para construir a identidade de Ruth, e três gerações compõem os estágios ou vidas do patriarca e personagem principal, Grange Copeland. Quando qualquer membro da família Copeland ou de uma específica geração de negros (de 1920 a 1960) ignora a dinâmica das estruturas familiares ou esquece a perspectiva histórica de que as estruturas são mantidas por meio da necessidade e do amor, ele ou ela perde a capacidade fundamental de identificar-se com a raça, a família e a comunidade, e perde também a base principal para definir-se como ser humano. O exemplo mais detalhado apresentado no romance é Brownfield, filho de Grange e membro da geração intermediária da obra." (Tradução minha). 
A segurança emocional de Ruth é construída através de duas fontes, a saber, a independência financeira e a estabilidade psicológica atingidas por Grange em sua terceira vida. Uma vez alcançados os pré-requisitos fundamentais para a construção de uma vida familiar saudável - dentro dos moldes preconizados pela sociedade norteamericana - Grange consegue oferecer a Ruth a tranqüilidade necessária para desenvolver mecanismos de defesa que a impeçam de cometer os mesmos erros de seus antepassados na condução de suas vidas.

É ainda dentro desta perspectiva de reconstrução e renovação que Ruth, já adolescente, encanta-se com o Movimento Pelos Direitos Civis e vê nele, ao contrário do avô, um ponto de partida para a abertura de um leque de possibilidades de mudanças na história da comunidade negra de seu país:

The epic of Grange Copeland is doubly transformational in that the character who will bear his experience into the future (both of the distant past which Grange passes along in the form of folk tales, and of the more recent past which Grange has directly known) is not a male heir, as more traditional literature might have it, but his granddaughter, whose coming of age is marked by sit ins, voter registration and the speeches of Martin Luther King, Jr. His own life marred by his struggle against bigotry, his own acts of violence, and the terrible racism and sexism of which he has been both a victim and an agent, Grange cannot be the embodiment of the future. Rather some great moment of rupture from the past is needed, and this Walker achieves in the transition from the male to the female principle. The novel ends on a note of affirmation - but not without uncertainty over the shape of the future. Ruth, Grange's granddaughter, is an adolescent and her future as well as the post-Civil 
Rights black community in the South cannot yet be told, but is, like the sixteen-year-old Ruth, on the threshold of its becoming. ${ }^{18}$

Vale observar que a escolha de Ruth como representante de uma geração que tem em suas mãos a responsabilidade de abraçar a causa negra e transformar os objetivos da luta da sua comunidade em realidade não foi feita aleatoriamente. A mulher, vista como agente de mudanças e renovação, reflete a posição da autora acerca das relações de raça e gênero, claramente centrada em suas convicções feministas.

\subsection{O ENCONTRO ENTRE FICÇÃO E HISTÓRIA}

\footnotetext{
${ }^{18}$ WILLIS, Susan. Walker's women. In: BLOOM, H. (ed.) Alice Walker. New York. Chelsea House Publisher. 1989. 245 p. p. 87-88. "A epopéia de Grange Copeland é duplamente transformadora no sentido de que o personagem que carregará sua experiência para o futuro (tanto aquela do passado remoto, que Grange transmite através de contos populares, quanto aquela do passado recente, que o próprio Grange vivenciou) não é um herdeiro do sexo masculino, como a literatura mais tradicional teria, mas sua neta, cuja chegada à idade adulta é marcada por "sit ins"*, "voter registration" * e os discursos de Martin Luther King, Jr. Com sua própria vida frustrada por sua luta contra a intolerância, seus próprios atos de violência, e o terrível racismo e machismo dos quais ele foi tanto uma vítima quanto um agente, Grange não pode ser a personificação do futuro. Um grande momento de ruptura com o passado se faz necessário, e Walker o realiza na transição do princípio masculino para o feminino. O romance termina com uma nota de afirmação - mas não sem incerteza sobre os contornos do futuro. Ruth, a neta de Grange, é uma adolescente e seu futuro, assim como aquele da comunidade negra do sul pós Movimento pelos Direitos Civis, ainda não pode ser previsto, mas está, assim como a Ruth de dezesseis anos de idade, no limiar de sua transformação. " (Tradução minha)

* SIT INS: Movimento liderado por estudantes negros que, em 1960, começaram a sentar-se em restaurantes, lojas, bibliotecas e demais lugares onde negros não eram atendidos e lá ficavam, pacificamente, aguardando atendimento.

* VOTER REGISTRATION: Movimento liderado por estudantes negros que, em 1963, após o assassinato de John F. Kennedy e a aprovação da Lei dos Direitos Civis, iniciaram um trabalho de conscientização, indo de porta em porta (muitas vezes visitando colonos em fazendas distantes) e convencendo a população negra, dividida entre o medo e a desesperança, a alistar-se como eleitores e, assim, fazer uso de seu direito ao voto.
} 
Em The third life of Grange Copeland, Alice Walker estabelece um vínculo estreito entre ficção e História e é através deste elo que a autora procura reestruturar a história dos afro-descendentes norte-americanos. A narrativa é pontuada por observações e comportamentos claramente determinados por momentos históricos cuja força atinge a família de forma inexorável, forjando personalidades e alterando rumos para o bem e para o mal.

Assim, a apresentação da saga da família Copeland tem início em 1920, com a descrição do menino Brownfield absolutamente deslumbrado com o carro novo de seu tio:

Brownfield stood close to his mother in the yard, not taking his eyes off the receding automobile. His uncle Silas slowed the car as it got to a place where a pointed rock jutted up out of the road: a week before he had busted an oil pan there. Once past this spot, which he had cursed as he passed to and fro over it during the week, he stuck out his arm and waved jauntily back at them. Brownfield waved sadly, his eyes blurred with tears. His aunt Marilyn, not visible through the rear window of the car, waved a dainty blue handkerchief from her front window. It fluttered merrily like a pennant. Brownfield's cousins had their faces pressed to the rear window, and their delicate, hard-to-see hands flopped monotonously up and down. They were tired of waving, for they had been waving good-bye since they finished breakfast.

The automobile was a new 1920 Buick, long and high and shiny green with great popping headlights like the eyes of a frog. Inside the car it was all blue, with seats that were fuzzy and soft. Slender silver handles opened the doors and rolled the astonishing clear windows up and down. As it bumped over the road its canvas top was scratched by low elm branches. Brownfield felt embarrassed about the bad road and the damage it did to his uncle's car. Uncle Silas loved his car and spent all morning washing it, polishing the wheel spokes and dusting 
off the running board. Now it bounced over gullies and potholes in the road, tossing Uncle Silas and his wife and children up in the air and slamming them down again. Brownfield sighed as the sound of metal against rock reached his ears. The road was for mules, wagons and bare feet only. ${ }^{19}$

A descrição do carro novo do "Tio Silas" - um Buick 1920 - acrescida da informação de que ele e sua família moram no norte do país, remete diretamente à "Grande Migração", ocorrida durante a Primeira Guerra Mundial.

Esta grande movimentação de trabalhadores rurais do sul do país em direção ao norte foi impulsionada por um forte esquema de propaganda que acenava com vantagens que, teoricamente, iriam propiciar ascensão social através do trabalho, levando à conquista da independência econômica. Tal fato, por sua vez, geraria liberdade individual.

[...] Black newspapers like the Chicago Defender painted an almost idyllic picture of life in the North, where Blacks could be free of the

\footnotetext{
${ }^{19}$ WALKER, Alice. The third life of Grange Copeland. New York.: Harcourt Books, 2003. 318 p. P. 3 $-4$.

"Brownfield permanecia perto de sua mãe no quintal, sem tirar os olhos do automóvel que se distanciava. Tio Silas reduzia a velocidade quando chegava a um trecho da estrada onde uma pedra pontiaguda projetava-se: uma semana antes ele havia furado um recipiente de óleo naquele lugar. Passado aquele ponto, o qual ele havia amaldiçoado em suas idas e vindas durante a semana, ele esticou o braço e abanou a mão garbosamente para eles. Brownfield acenava tristemente, com os olhos marejados de lágrimas. Sua tia Marilyn, invisível através do vidro traseiro do carro, agitava um delicado lenço azul da janela dianteira. Ele agitava alegremente como uma bandeira. Os primos de Brownfield comprimiam seus rostos no vidro traseiro, e suas mãos delicadas, difíceis de enxergar, acenavam monotonamente. Eles estavam cansados de acenar, pois vinham se despedindo desde que haviam terminado o café da manhã. $\mathrm{O}$ automóvel era um Buick novo, de 1920, comprido e alto, de um verde reluzente, com grandes faróis que saltavam como os olhos de uma rã. O interior do carro era todo azul, com assentos fofos e macios. Elegantes maçanetas prateadas erguiam e abaixavam os vidros admiravelmente limpos. Conforme ele saltava na estrada, sua capota de lona era arranhada pelos galhos mais baixos dos olmos. Brownfield sentia-se embaraçado com a estrada ruim e o dano que ela causou ao carro do seu tio. Tio Silas amava seu carro e passava a manhã inteira lavando-o, polindo a roda e removendo a poeira do estribo. Agora ele saltava as valas e buracos da estrada, arremessando tio Silas, sua mulher e filhos para cima e jogando-os novamente para baixo. Brownfield suspirava quando o som do metal contra as pedras chegava a seus ouvidos. A estrada era apropriada apenas para mulas, carroças e pés descalços.” (Tradução minha)
} 
lynch mob and "live anywhere they wanted" Parents could send their children to good integrated public schools. And you could vote in the North.

Some 227,000 Blacks moved north during the decade 1910-1920, as opposed to only 79,000 migrants between 1880 and 1910. Between 1920 and 1930, the number reached 440,000. Industrialist George Pullman was paying almost $\$ 2$ a day at his railroad sleeping-car factory outside Chicago. Steel mills in Gary, Indiana, were paying nearly $\$ 1.50$ a day. And Henry Ford was reportedly paying the unheard of sum of $\$ 5$ per day, as compared to 15 to 50 cents per day for Southern farm laborers. ${ }^{20}$

Era uma fase de franca expansão das indústrias nortistas, às voltas com um déficit de mão de obra gerado pela redução do número de imigrantes europeus e pelo envolvimento dos Estados Unidos na Primeira Guerra Mundial. De fornecedor de armas, munições, alimentos e outros produtos básicos para as potências européias envolvidas no conflito, o país acabou por se envolver diretamente na Grande Guerra, em 1917, declarando guerra à Alemanha. Tal decisão implicou em enviar um grande número de soldados para o front, aumentando, portanto, a necessidade de incentivar a migração da mão-de-obra camponesa do sul para as cidades industrializadas do norte.

Assim como "Tio Silas", Grange também é seduzido pelas imagens de prosperidade oferecidas pelo norte do país, partindo para lá quando todas as suas expectativas de vida digna no sul foram frustradas.

\footnotetext{
${ }^{20}$ LINDSEY, Howard O. A history of Black America. London: Bison Books, 1994. 160 p. P. 98-99. "Jornais negros como o Defensor de Chicago pintavam um quadro quase idílico da vida no norte, onde os negros poderiam se ver livres de linchamentos e "morar onde quisessem". Os pais poderiam enviar seus filhos para boas escolas públicas integradas. E você poderia votar no norte,

Cerca de 227.000 negros mudaram-se para o norte durante a década de 1910-1920, em oposição a apenas 79.000 migrantes entre 1880 e 1910. Entre 1920 e 1930 atingiu-se o número de 440.000. O industrial George Pullman estava pagando quase US\$2,00 por dia em sua fábrica de vagões nos arredores de Chicago. Usinas de aço em Gary, Indiana, estavam pagando quase US $\$ 1,50$ por dia. E Henry Ford, segundo se dizia, estava pagando a fantástica quantia de US $\$ 5,00$ por dia, se comparada com 15 a 50 centavos de dólar por dia pago a trabalhadores da lavoura sulista." (Tradução minha).
} 
Seu retorno, com algum dinheiro, mas marcado pela frieza e indiferença da cidade grande, é uma representação simbólica do fim do sonho de muitos migrantes negros que trocaram a condição de semi-escravos do sul pela condição de pobres moradores de guetos situados nas periferias das grandes cidades industriais.

The worst economic calamity in the nation's history began with the stock-market collapse of October 1929 and eclipsed all previous depressions in its duration and severity. By this time, millions more were part of the urban-based industrial society, totally dependent on weekly wages for the necessities of life [...]

For African-Americans the situation was even more critical. "Last hired and first fired" was the attitude of many employers toward Black workers. This was due in part to the fact that Whites took many jobs the dirtiest, most dangerous, and lowest-paid - formerly held by Blacks. Faced with losing their livelihoods, many White workers gladly accepted such jobs, with the result that Black unemployment in some cities was over 70 percent. The Chicago Defender warned its readers to "head for the country before the snow flies." The great Northern migration stalled to a halt during the 1930s. There simply were no jobs. ${ }^{21}$

Mais maduro e experiente, Grange traz consigo novos valores acerca das questões de raça e se empenha em transmiti-los para a neta. Assim, ele realiza todo um

\footnotetext{
${ }^{21}$ LINDSEY, Howard O. A history of Black America. London: Bison Books, 1994.160 p. P.109. "A pior calamidade econômica da história da nação começou com o colapso do mercado de ações em outubro de 1929 e superou todas as depressões anteriores em duração e gravidade. Nessa época, mais de milhões eram parte da sociedade industrial urbana, totalmente dependente de pagamentos semanais para suprir suas necessidades [...]

Para os afro-americanos a situação era ainda mais crítica. "Último a ser contratado e primeiro a ser demitido" era a postura de muitos empregadores em relação aos trabalhadores negros. Isto se devia em parte ao fato de que os brancos aceitavam muitos trabalhos - os mais sujos, mais perigosos e mais mal pagos - anteriormente executados pelos negros. Deparados com a perda de seu sustento, muitos trabalhadores brancos aceitavam alegremente tais trabalhos, tendo como conseqüência o índice de desemprego dos negros em algumas cidades acima de setenta por cento. O Chicago Defender aconselhou seus leitores a "rumar para o campo antes da neve cair." A grande migração para o norte chegou ao fim durante os anos de 1930. Simplesmente não havia trabalho." (Tradução minha)
} 
trabalho para fazer com que Ruth aceite e goste de suas características físicas: ao invés de tentar atingir o padrão de beleza das meninas brancas, Ruth é incentivada a sentir orgulho de seus traços africanos e a valorizar a beleza de seu corpo, é impedida de alisar ou mudar a cor dos seus cabelos e é encorajada a cuidar deles e valorizá-los como realmente são.

Ruth também é encorajada a estudar e, em suas conversas com o avô, aprende muito sobre as tradições indígenas e africanas: as estórias, as músicas, as danças. Grange empenha-se em mostrar-lhe a existência de um passado digno e culturalmente rico, procurando fazer com que a neta não só se identifique com seus ancestrais africanos, mas também sinta orgulho de suas origens.

Todo este trabalho, aliado à busca e concretização da independência financeira, revela-se como um reflexo direto da influência exercida pelo jamaicano Marcus Garvey e sua Associação Universal para o Progresso Negro (Universal Negro Improvement Association).

Criada em 1914 na Jamaica, sua associação rapidamente espalhou-se pelo mundo e exerceu forte influência sobre as comunidades negras da época e sobre as gerações seguintes. Nos Estados Unidos da América, Garvey encontrou terreno fértil para a divulgação de seus ideais: durante sua estada no país (1916-1927) ele arrebanhou um grande número de seguidores, responsáveis por transformar a região na base de operações da UNIA com o maior número de filiais lá instaladas.

Figura polêmica, Garvey empenhou-se em promover a unidade da comunidade afro-descendente através de sua conscientização. Ele protestava contra o preconceito racial e a desintegração dos valores africanos, e propunha uma volta às origens, exaltando todos os aspectos relacionados aos povos africanos: a história, a cultura, bem 
como as características físicas que os distinguiam das demais etnias. Tal aprendizado aconteceria em escolas para negros que teriam a cultura africana em seu currículo.

Em sua estada nos Estados Unidos Garvey publicou o jornal O Mundo Negro, no Harlem, que se caracterizava como um espaço valioso de expressão para a comunidade negra bem como um veículo importante para a transmissão de ideais libertários e a construção da auto-estima dos afro-descendentes. Em seu jornal, negava-se a publicar anúncios de produtos que ele considerava degradantes para os negros, tais como clareadores de pele e alisantes de cabelo.

Completando a relação entre ficção e História, no penúltimo capítulo do romance a autora apresenta o Movimento Pelos Direitos Civis. A princípio, Grange e Ruth tomam conhecimento do Movimento através das imagens exibidas pela televisão. As grandes passeatas promovidas pelos jovens militantes, bem como a forte repressão policial que sofriam, aliadas aos discursos libertários e motivadores de Martin Luther King inspiravam otimismo, mas, ao mesmo tempo, revelavam-se absolutamente distantes da realidade do avô e sua neta, confinados no interior do sul do país.

O Movimento somente se materializa para ambos com a chegada dos militantes em Baker County, no início das férias escolares, e a visão perturbadora de brancos e negros marchando pelas ruas de mãos dadas.

And then it was spring and school was over and the student marchers were in Baker County. Ruth saw a long line of them parading up and down the streets when she went into town. Their signs were strange and striking. I AM AN AMERICAN TOO! said one. THIS IS MY COUNTRY TOO! said another. I WANT FREEDOM TOO! said still another. Although she had seen marchers before on television she was amazed to see real blacks and whites marching together in her home town! There were trim white girls in jeans and sneakers with clean 
flowered blouses marching next to intense black girls in high heels and somber Sunday dresses. There were dozens of young black and white male marchers; it looked peculiar to Ruth to see them whispering confidences to one another, curious that she could detect no sign of mutual disgust. "Are they for real?" she wondered. She watched wide-eyed, her glances moving from the marchers to the residents of Baker County. Baker County had been so surprised by the students' arrival it had not done anything yet. Even the sheriff stood on a street corner and stared with his mouth slightly open. His deputies hung around him, so closely it looked as if they needed protection, or at best, minute instructions on how to handle the demonstrators. Local blacks and whites stood under the trees on the courthouse lawn and gawked at the white girls. Some of the men sneered and called them dirty names. Of all the people marching the white girls got the most abuse. One of them carried a sign that said BLACK AND WHITE TOGETHER and each time she passed a group of whites they spat at her and hissed "I'll bet! One of them added, aiming a Coke bottle at her, "you nigger-fuckin' whore!" Ruth passed close beside this girl and noticed her right ear, the one next to the bystanders, was bleeding, and that she marched with stiff wooden steps as if to a chilling inner music. Tears slipped quietly and endlessly down her pale cheeks and the sign in her hand had begun to waver. $^{22}$

\footnotetext{
${ }^{22}$ WALKER, Alice. The third life of Grange Copeland. New York.: Harcourt Books, 2003. 318 p. P. 295 - 296. "E então era primavera, as aulas haviam acabado e os estudantes ativistas estavam em Baker County. Ruth viu uma longa fila deles desfilando pelas ruas quando ela entrou na cidade. Seus cartazes eram estranhos e surpreendentes. EU SOU AMERICANO TAMBÉM! dizia um. ESTE PAÍS É MEU TAMBÉM! dizia outro. EU TAMBÉM QUERO LIBERDADE! um outro ainda dizia.Embora ela tivesse visto ativistas antes na televisão, ela estava espantada ao ver negros e brancos reais marchando juntos em sua cidade natal! Havia garotas brancas vestindo jeans e tênis, com blusas limpas e floridas, desfilando ao lado de garotas negras usando saltos altos e sóbrios vestidos de domingo. Havia dúzias de manifestantes brancos e negros: era esquisito para Ruth vê-los cochichando, curioso não conseguir detectar nenhum sinal de aversão mútua. "Eles são reais?"ela se perguntava. Ela observava com olhos arregalados, seu olhar movendo-se dos manifestantes para os moradores de Baker County. Baker County tinha ficado tão surpresa com a chegada dos estudantes que ainda não havia feito nada. Até o xerife estava parado em uma esquina, espantado, com a boca ligeiramente aberta. Seus auxiliares a seu lado, tão perto que parecia que eles precisavam de proteção ou, na melhor das hipóteses, de instruções detalhadas de como lidar com os manifestantes. Os negros e brancos locais deixavam-se ficar embaixo das árvores no gramado do fórum e olhavam aparvalhados para as moças brancas. Alguns homens olhavam com desprezo e as xingavam, De todas as pessoas que marchavam, as garotas brancas eram as mais desrespeitadas. Uma delas carregava um cartaz que dizia NEGROS E BRANCOS JUNTOS e cada vez que ela passava por um grupo de brancos eles cuspiam nela e sibilavam "eu aposto! Um deles acrescentou, apontando uma garrafa de cocacola para ela "sua puta de negros!" Ruth passou bem perto da moça e notou que a sua orelha direita, aquela que ficava próxima dos espectadores, estava sangrando, e que ela marchava com passos firmes,
} 
Este acontecimento provoca reações diferentes em Ruth e em Grange: o avô, que experimentou todas as formas de racismo e opressão - e suas conseqüências - ao longo de sua existência, não consegue acreditar na possibilidade de haver uma relação entre negros e brancos diferente daquela que sempre conheceu; porém a neta, jovem e idealista, vislumbra o nascimento de novos tempos onde a visão maniqueísta de Grange acerca das relações raciais deixará de ter sentido.

A presença dos jovens militantes no povoado rompe o equilíbrio da ordem há muito tempo estabelecida, provoca reações hostis e faz com que Grange entre em contato com uma nova realidade, na qual não acredita, mas que o surpreende, por revelar a coragem - inocente, a seu ver - da nova geração de afro-descendentes.

"My name is Quincy," the young man said, "and this is my wife, Helen.” $[\ldots]$

“.Mr. Copeland,” said Quincy, “do you vote?” Ruth had given him water too and he sipped it, looking very relaxed on the banister, with one leg dangling over the side.

"Vote for what?" asked Grange.

"For sheriff and governor and police chief and county commissioner."

"Nope," said Grange.

"Why not?" asked Helen. She had finished half her glass of water and now rubbed the bottom of the glass over the top of her belly as if to cool it.

"Cause every one of 'em is crackers," said Grange, "an' there ain't a teaspoon of difference between one cracker and another."

Quincy laughed. Helen laughed too, but then said firmly, "That's not what we found out in Green County."

como se estivesse seguindo uma arrepiante música interior. Lágrimas intermináveis escorriam por seu rosto pálido e o cartaz em sua mão começou a tremer." (Tradução minha). 
Grange snorted. "I used to live there," he said with authority, "an' I don't know what you found, but it wasn't that crackers'd let niggers vote. Last hanging they had was some nigger trying to cast his vote for the cracker of his choice."

"Well," said Quincy, "they voting for the cracker of they choice now."

“They voting now?" asked Grange.

"Yep!" said Quincy. "We worked there last summer. They're voting in droves."

"Ain't a cracker in Green County worth the bother," said Grange.

"What about black folks?" asked Helen.

"The black folks wasn't shit neither when I was there," said Grange. "Everyone that wanted to try somethin' to help his people got knifed in the back by 'em." He took out his pipe and began pulling on it, chewing the stem. "You don't mean to tell me that some fool of ours is trying to run for office in Green County, do you"? he asked.

"Not this year," said Helen.

"Where you from, girl?" asked Grange sharply.

"Green County," she answered sweetly, laughing at him.

"Well, I be damned," said Grange. He felt he had been caught sleeping, and that his nap had lasted twenty or forty years [...]

"Quincy's going to run for mayor," said Helen. "I'm going to be first lady of Green County."

"You're all crazy," said Grange. "you best be spending your energy in getting yourselves out of here. How long you think you going to be able to laugh like you do?" he asked Helen.

"I ain't going to let them make me stop!" she said.

And Grange thought, You may keep being able to laugh when other peoples is around, but when you and your husband and the baby is all alone dodging bullets and jumping out of your skin at every noise, will you be able to laugh then? He imagined Helen in ten years, her young husband maybe buried in some swampy unmarked grave, her child hounded by grownups and children who hated niggers. He saw her at the mercy of some white town whose every gesture would mean she was worthless, an intruder, an American on good behavior. Suppose she couldn't ever become "first lady" of anything. Then where would her laughter be? 
We want you to register," said Quincy. "I even got my mother to register, though she swears she's been hexing the bad crackers all along!"

"I can't promise you," said Grange. He felt a deep tenderness for the young couple. He felt about them as he felt about Dr. King; that if they'd just stay with him on his farm he'd shoot the first cracker that tried to bother them. He wanted to protect them from themselves and from their dreams, as much as from the crackers. He would not let anybody hurt them, but at the same time he didn't believe in what they were doing. Not because it wasn't worthy and noble and inspiring and good, but because it was impossible.

"What I'm scared of, children, is the bitterness; the taste of bile thrown up by the liver when you finds out the fight can't be won."

Quincy put his arm around his wife, his hand moving up and down her side. He held her loosely yet completely, as if she meant everything to him, and the glow in her eyes was pure worship when she looked up at him. Grange was touched almost to tears by the simplicity and directness of their love and he shuddered with fear for them.

"If you fight," she said, placing soft black fingers on Grange's arm, "if you fight with all you got, you don't have to be bitter. ${ }^{23}$

${ }^{23}$ WALKER, Alice. The third life of Grange Copeland. New York: Harcourt Books, 2003. 318 p. P. 300-303.

"Meu nome é Quincy," o jovem disse, “e esta é minha esposa, Helen.” [...] "Senhor Copeland, “ disse Quincy, "o senhor vota?" Ruth tinha dado água para ele também e ele a sorvia, parecendo muito tranqüilo encostado ao balaústre, com a perna balançando do outro lado. "Votar para que?" perguntou Grange. "Para xerife, governador, chefe de polícia e comissário do condado." "Não," disse Grange. "Por que não?", perguntou Helen. Ela tinha tomado metade do seu copo de água e agora deslizava a base do copo pela sua barriga como se quisesse refrescá-la. "Porque eles tudo é explorador," Grange disse, "e não tem uma colher de chá de diferença entre um explorador e outro.". Quincy riu. Helen riu também, mas depois disse firmemente, "Isso não é o que nós encontramos em Green County." Grange bufou: "Eu morei lá, " ele disse com autoridade, “ e eu não sei o que você encontrou, mas os sem-vergonha não deixava os negro votar. $\mathrm{O}$ último enforcamento que tiveram foi de um negro tentando dar seu voto para o sem-vergonha de sua escolha." "Bem, disse Quincy, "eles tão votando para o explorador de sua escolha agora." "Eles tão votando agora?’'Grange perguntou. "Sim!”, disse Quincy. Nós trabalhamos lá no verão passado. Eles estão votando em massa. "Não tem um explorador em Green County que valha a pena," disse Grange. "Que tal os negros?"Helen perguntou. “Os negros não eram merda nenhuma quando eu estava lá," Grange disse. "Todo aquele que queria tentar alguma coisa para ajudar seu povo levava uma facada deles nas costas." Ele pegou seu cachimbo e começou a brincar com ele, mordendo a base. "Você não está tentando me dizer que um tolo dos nossos está se candidatando para comissário em Green County, está?"'ele perguntou. "Não este ano," Helen disse. "De onde você é, menina?"Grange perguntou asperamente. "Green County," ela respondeu docemente, rindo de Grange. "Bem, eu sou um amaldiçoado," Grange disse. Ele sentia que havia sido pego dormindo e que o seu cochilo tinha durado vinte ou quarenta anos [...] "Quincy vai se candidatar a prefeito," Helen disse. "Eu vou ser primeira dama de Green County." "Vocês são todos loucos," Grange disse, "é melhor você gastar sua energia sumindo daqui. Por quanto tempo você acha que vai continuar rindo assim?"ele perguntou a Helen. "Eu não vou 
O encontro de Grange com o casal de militantes do Movimento, e o diálogo

travado por eles, evidencia as diferenças entre gerações; de um lado, o contraste entre a experiência e a conseqüente desilusão por ela gerada e, de outro, a ousadia e a coragem de se comprometer e de se empenhar para alcançar um ideal.

A nova geração de afro-descendentes das décadas de sessenta e setenta trilhava um caminho em busca da renovação e da mudança radical das relações étnicas e sociais. Naquele contexto, para que a nova geração pudesse trabalhar para realizar seus sonhos, os representantes das gerações anteriores, na narrativa representados por Grange e Brownfield, precisavam se afastar. E o seu afastamento ocorre da forma mais trágica possível: o pai mata o filho e é posteriormente assassinado pela polícia.

\subsection{BROWNFIELD COPELAND}

deixá-los me calar!"ela disse. E Grange pensou. Você pode continuar sendo capaz de rir enquanto outras pessoas estiverem com você, mas quando você, o seu marido e o seu bebê estiverem completamente sozinhos, esquivando-se das balas e pulando de susto a cada barulho, você será capaz de rir? Ele imaginou Helen daí a dez anos, seu jovem marido talvez enterrado em algum túmulo não identificado, sua criança perseguida por adultos e crianças que odiassem negros. Ele a viu à mercê de alguma cidade branca cujos gestos indicariam que ela era desprezível, uma intrusa, uma americana bem comportada. Suponha que ela nunca conseguisse se tornar "primeira dama" de nada. Então onde estaria sua risada? "Nós queremos que o senhor se inscreva," Quincy disse. "Eu até consegui que minha mãe se inscrevesse, embora ela jure que está amaldiçoando os maus exploradores o tempo todo!" "Eu não posso te prometer," Grange disse. Ele sentia uma ternura profunda pelo jovem casal. Sentia por eles o mesmo que sentia pelo Dr. King: que se eles ficassem com ele em sua fazenda ele atiraria no primeiro sem-vergonha que tentasse incomodá-los. Ele queria protegê-los de si mesmos e de seus sonhos, bem como dos exploradores. Ele não deixaria ninguém feri-los, mas ao mesmo tempo ele não acreditava naquilo que eles estavam fazendo. Não porque não era digno e nobre e inspirador e bom, mas porque era impossível. "O que me dá medo, crianças, é a amargura, o gosto da bile lançada pelo fígado quando você descobre que a luta não pode ser vencida." Quincy enlaçou sua esposa, sua mão movendo-se para cima e para baixo. Ele a segurava frouxamente, porém completamente, como se ela significasse tudo para ele, e o brilho nos olhos dela quando o olhava era pura adoração. Grange ficou comovido, quase chegando às lágrimas, com a simplicidade e a clareza de seu amor e ele tremeu de medo por eles. "Se você lutar," ela disse, colocando macios dedos negros no braço de Grange, "se você lutar com todas as suas forças, você não terá que ser amargo. (Tradução minha). 
Brownfield é o representante da segunda geração dos Copeland, fruto do casamento de Grange com Margaret.

Sua infância e adolescência, marcadas por relações familiares traumáticas que o levaram a ser negligenciado e posteriormente abandonado, de maneiras diversas, pelos pais, bem como a idade adulta degradante, quase inumana, já foram descritas neste estudo. Outro aspecto importante de sua formação, porém, merece um olhar mais apurado: seu pertencimento a uma sociedade cujas estruturas de pensamento foram geradas pelo capitalismo.

Assim, o deslumbramento do menino Brownfield diante do carro novo do "Tio Silas" já sinaliza o seu futuro: um eterno peregrino em busca do paraíso, simbolizado então pelo norte do país e pelo "Buick" de seu tio.

Possuir produtos significa ser feliz; o carro do "Tio Silas" fala por si só do sucesso pessoal alcançado por ele, que é visto como contraponto do pai de Brownfield, um eterno fracassado. $\mathrm{O}$ menino não quer fazer parte daquele mundo frio $\mathrm{e}$ desencantado, estruturado nas relações humanas pré-fixadas.

Brownfield watched the automobile as it turned a curve and was finally out of sight. Then he watched the last of the dust settle. Already he missed his cousins, although they made him feel dumb for never having seen a picture show and for never having seen houses stacked one on top of the other until they nearly reached the sky. They had stayed a week and got over being impressed by his small knowledge of farming the first day. He showed them how to milk the cow, how to feed the pigs, how to find chickens' eggs; but the next day they had bombarded him with talk about automobiles and street lights and paved walks and trash collectors and about something they had ridden in once in a department store that went up, up, up from one 
floor to the next without anybody walking a step. He had been dazzled by this information and at last overwhelmed. They taunted him because he lived in the country and never saw anything or went anywhere. They told him that his father worked for a cracker and that the cracker owned him. They told him that their own daddy, his Uncle Silas, had gone to Philadelphia to be his own boss. They told him that his mother wanted to leave his father and go North to Philadelphia with them. They said that his mother wanted him, Brownfield, to go to school, and that she was tired of his father and wanted to leave him anyway. His cousins told Brownfield this and much more. They bewildered, excited and hurt him. Still, he missed them: they were from a world he had never seen. Now that they were gone he felt the way he usually felt only in winter, never in June; as if he were waiting for something to happen that would take a very long time to come.

"I wish we lived in Philadelphia," he said.

"Well, we don't." that was his father.

[...] "Uncle Silas like to talk about his automobile," said Brownfield, his lips bumbling over the word. It was his uncle's word, a city word. In the country they always said car. Some people still called them buggies, as if they could not get used to a conveyance that did not use horses.

"I wish we had a automobile like that!"

"Well, we don't."

"No, we don't," said Margaret. ${ }^{24}$

\footnotetext{
${ }^{24}$ Ibid. p. 4 -5. "Brownfield observou o automóvel enquanto ele fazia a curva e finalmente sumia de vista. Depois, ele assistiu o último resquício de poeira se assentar. Ele já sentia saudades de seus primos, mesmo que eles o fizessem sentir-se tolo por nunca ter visto um filme e por nunca ter visto casas empilhadas umas nas outras até que elas quase alcançassem o céu. Eles ficaram por uma semana e pararam de ficar impressionados com seu pequeno conhecimento sobre agricultura no primeiro dia. Ele os mostrou como tirar leite da vaca, alimentar os porcos, como procurar os ovos das galinhas; mas no dia seguinte eles o bombardearam com conversas sobre automóveis, luzes da rua, calçadas pavimentadas, coletores de lixo e sobre alguma coisa em que eles andaram numa loja de departamentos que ia subindo, subindo, subindo de um andar para outro sem que ninguém tivesse que subir um degrau. Ele havia ficado maravilhado com estas informações e por fim confundido. Eles zombavam dele porque ele vivia no interior e nunca via nada ou ia a lugar algum. Eles lhe disseram que seu pai trabalhava para um explorador e que o explorador era dono dele. Eles contaram que seu pai, seu tio Silas, tinha ido para a Filadélfia para ser seu próprio patrão. Eles lhe disseram que a sua mãe queria abandonar seu pai e ir para o norte, para a Filadélfia, com eles. Eles disseram que sua mãe queria que ele, Brownfield, fosse para a escola, e que ela estava cansada do seu pai. Seus primos lhe disseram isso e muito mais. Eles o confundiam, excitavam e machucavam. Mesmo assim ele sentia falta deles: eles eram de um mundo que ele nunca tinha visto. Agora que eles tinham ido embora, ele se sentia do jeito que ele se sentia somente no inverno, nunca em junho; como se estivesse esperando por algo que demoraria muito tempo para acontecer. "Eu gostaria de morar na Filadélfia," ele disse. "Bom, nós não." esse era seu pai. [...] O tio Silas gosta de falar do seu automóvel," disse Brownfield, seus lábios tremendo com a palavra. Era a
} 
O fascínio do garoto pelo carro do tio evidencia o "jogo mágico" da cultura capitalista que estabelece critérios de diferença através de valores atribuídos à mercadoria e que são transferidos para seus possuidores. O carro, neste caso, é o símbolo privilegiado de um sistema proclamado como democrático e integrador, mas que na verdade estabelece critérios de diferença entre os indivíduos.

O carro do tio não atrai Brownfield pelo seu valor de uso, mas sim por tudo o que ele representa: a "riqueza" do "Tio Silas", conquistada no "distante, desconhecido e atraente norte do país", região que proporciona aos primos experiências que ele nunca teve, que os coloca em uma posição superior à sua, que faz com que eles tenham "uma família e uma vida feliz".

Tendo como base a visão marxista de que as mercadorias são conteúdo de relações sociais ocultas, pode-se afirmar que o carro do "Tio Silas" simboliza o primeiro contato do menino com o significado social dos bens de consumo. Seus primos já experimentam esta realidade, uma vez que vivem em uma região onde a sociedade capitalista está em franco desenvolvimento.

O desejo de possuir um carro como aquele de seu tio não tem origem em necessidades básicas, mas sim em necessidades culturais e existenciais. Brownfield não vê o carro como algo útil à sua vida ou à de seus pais, tampouco ao trabalho com a terra - função esta, aliás, que o veículo não poderia ter. Na verdade, a posse do carro simboliza a condição de igualdade com seu modelo e opressor: o homem branco,

palavra do seu tio, uma palavra da cidade. No interior eles sempre diziam carro. Algumas pessoas ainda o chamavam de carroça, como se não pudessem se acostumar com um veículo que não usasse cavalos. "Eu queria que nós tivéssemos um automóvel como aquele!" "Bom, nós não queremos." "No, nós não queremos," disse Margaret.” (Tradução minha). 
proprietário de terras, bem situado econômica e socialmente, representante de um mundo que o menino ainda não sabe ser inalcançável.

\begin{abstract}
Apesar de serem produzidos em massa, a maioria dos bens de consumo é colocada no mercado visando consumidores específicos e geralmente apresentam detalhes de estilo que servem para diferenciar classe social, raça e gênero. Essa diferenciação pode parecer meramente estilística e superficial, mas ela se origina de uma sociedade na qual diferença significa desigualdade social. Como o estilo do produto é visto com tanta naturalidade, ele serve para trivializar e perpetuar a idéia de desigualdade e subordinação. ${ }^{25}$
\end{abstract}

Representante da segunda geração dos Copeland, Brownfield tem necessidades que vão além daquelas de seus pais, pois vive em uma época em que a cultura de seu país já havia se consolidado como sendo a cultura branca, regida pelo capital e pelos meios de comunicação de massa. ${ }^{26}$

Muito jovem ainda, Brownfield é mais suscetível aos apelos da ideologia da sociedade de consumo, fato este que o torna mais frágil e potencializa seu futuro fracasso uma vez que é presa fácil da contradição desta ideologia. Ele não sabe ainda e, em toda a sua trajetória, jamais compreenderá sua posição nesta grande teia, claramente explicada por Susan Willis como "a contradição da sociedade de consumo, que quer nos convencer a todos de que no mundo dos bens de consumo somos todos iguais, e a realidade dos marginalizados, para quem o modelo dominante branco é impossível." (1997, p. 136)

\footnotetext{
${ }^{25}$ WILLIS, Susan. Cotidiano: para começo de conversa. Rio de Janeiro: Graal, 1997. p. 195.

${ }^{26}$ Ibid. p. 129.
} 
A relação entre consumo e status social norteará a trajetória de Brownfield, condenado a correr atrás do sonho americano do vencedor onde o ter e o consumir configuram-se como o sentido último da vida.

As he stroked his shoes caressingly with the rag, Brownfield sank into a favorite daydream. He saw himself grown-up, twenty-one or so, arriving home at sunset in the snow. [...] In his daydream he pulled up to his house, a stately mansion with cherry-red brick chimneys and matching brick porch and steps, in a long chauffeur-driven car. The chauffeur glided out of the car first and opened the back door, where Brownfield sat puffing on a cigar. Then the chauffeur vanished around the back of the house, where his wife waited for him on the kitchen steps. She was the beloved and very respected cook and had been with the house and the chauffeur and Brownfield's family for many years. Brownfield's wife and children - two children, a girl and a boy waited anxiously for him just inside the door in the foyer. They jumped all over him, showering him with kisses. While he told his wife of the big deals he'd pushed through that day she fixed him a mint julep. After a splendid dinner, presided over by the cook, dressed in black uniform and white starched cap, he and his wife, their arms around each other, tucked the children in bed and spent the rest of the evening discussing her day (which she had spent walking in her garden) and making love.

There was one thing that was odd about the daydream. The face of Brownfield's wife and that of the cook constantly interchanged. So that his wife was first black and glistening from cooking and then white and powdery to his touch; his dreaming self could not make up its mind. His children's faces were never in focus. He recognized them by their angelic presence alone, two bright spots of warmth; they hovered about calling him "Daddy" endearingly, while he stroked the empty air, assuming it to be their heads. ${ }^{27}$

${ }^{27}$ WALKER, Alice. The third life of Grange Copeland. New York: Harcourt Books, 2003. 318 p. P.2122.

"Enquanto acariciava seus sapatos carinhosamente com um trapo, Brownfield mergulhava em seu devaneio favorito. Ele se via adulto, com vinte e um anos ou tanto, chegando em casa ao por do sol, na 
A passagem acima - um devaneio de Brownfield já adolescente - é representativa das contradições da sociedade de consumo vivenciadas pelo personagem. Movido pelo desejo de ascensão social, o rapaz imagina-se como um típico representante da classe média sulista norte-americana: é um homem de negócios bem sucedido, casado, pai de dois filhos, que possui uma bela casa, um carro de alto padrão e empregados para servi-lo. Os empregados são negros, e é neste ponto que seu devaneio torna-se complicado: sua esposa é a mulher branca, perfumada e bem tratada ou é a mulher negra com o rosto suado e oleoso de tanto trabalhar na cozinha? Quais são as características físicas de seus filhos? Brownfield não consegue visualizá-los, apenas sentir sua presença.

A felicidade, advinda de seu status social e de suas relações familiares amorosas e harmônicas, não pode ser sentida em sua plenitude, uma vez que ele não consegue situar-se como membro de uma classe social ou de um grupo étnico. É neste momento que as questões sociais se entrelaçam com as questões raciais: para viver seu sonho vitorioso ele deveria ser branco; como não é, seus sentimentos tornam-se confusos, e a

neve. [...] Em seu devaneio ele parava na sua casa, uma mansão suntuosa com chaminés de tijolo vermelho cereja, varanda de tijolos e degraus que combinavam, em um grande carro dirigido por um chofer. O chofer deslizava para fora do carro e abria a porta traseira, onde Brownfield estava sentado fumando um charuto. Depois o chofer desaparecia nos fundos da casa, onde sua mulher o esperava nos degraus da cozinha. Ela era a amada e muito respeitada cozinheira que estava na casa com o chofer e a família de Brownfield há muitos anos. A esposa e os filhos de Brownfield - duas crianças, uma menina e um menino - esperavam ansiosamente por ele no vestíbulo. Eles o rodeavam alegremente, cobrindo-o de beijos. Enquanto ele contava para sua esposa os grandes negócios que havia realizado naquele dia, ela lhe preparava um licor de hortelã. Depois de um jantar magnífico, presidido pela cozinheira, vestida com uniforme preto e uma touca branca engomada, ele e sua esposa, abraçados, punham as crianças para dormir e passavam o resto da noite conversando sobre o dia dela (que ela havia passado caminhando em seu jardim) e fazendo amor.

Havia uma coisa estranha em seu devaneio. O rosto da esposa de Brownfield e o da cozinheira constantemente se confundiam. De forma que ora sua esposa era negra e reluzente do trabalho na cozinha, ora era branca e macia ao seu toque; seu eu sonhador não conseguia se decidir. Os rostos de seus filhos nunca eram nítidos. Ele os reconhecia apenas pela sua presença angelical, dois pontos luminosos de calor; eles o rodeavam chamando-o amorosamente de "Papai" enquanto ele acariciava o vazio, pressupondo ser suas cabeças." (Tradução minha) 
única identificação possível se faz com aqueles que estão em uma condição subalterna, os empregados negros e pobres.

Sua dificuldade em situar-se social e etnicamente já indica que o percurso a ser percorrido está fadado ao fracasso. Em sua vida adulta Brownfield colhe uma sucessão infinita de derrotas, com uma breve pausa somente quando Mem assume o comando da família.

Tendo recebido uma educação escolar, portanto dentro dos valores básicos da cultura norte-americana, Mem assimila, de forma mais intensa que Brownfield, a idéia do sonho americano do ter e do consumir. É em busca deste sonho que, em dado momento, usando contra o marido a mesma violência que ele dirigia a ela e às filhas, Mem assume o controle da família e consegue subir um pequeno patamar na escala social.

In the city house, a "mansion" of four sheetrocked rooms, no holes, a grassy yard and a mailbox on the porch, he lay low in his role. He played his conversion by terror long after the terror was gone and was replaced by a great design to express his rage, his humiliation, his deep hatred.

During the day at his job in a frozen pie factory, he was in a rage against his own contentment. It did not seem fair to him that the new work should actually be easier than dairying or raising cotton or corn. True, there was the boring placing of trays of peach pies on the assembly line, but after tramping for years after white folks' cows, the monotony soothed him. The even coolness of the building almost made him forget the stifling heat of the fields. His hands were drier now, for he could and did wear rubber gloves whenever there was wet work to do. He enjoyed pouring the mixture for the pies into the big vats, and liked regulating the hoses for water into the pressure cookers, and looked forward every day to washing up the big, shiny, always new, utensils. 
At the new house too there was a feeling of progress. An indoor toilet with a white tub, a face bowl, mirror and white commode. Now he could shit, and rising, look at himself, at the way his eyes had cleared themselves of the hateful veins and yellow tigerish lines, without much odor or rain, and much like a gentleman; or, as he invariably thought of it, like a white man. (grifo nosso)

He was cowed into wielding a paintbrush against dingy walls, planting bushes, attempting to fix the faulty wiring. For there were electric lights, and he was sometimes moved to read (look through the pictures of) the catalogues his wife got in the mail. The pictures of the new clothes and the guns and the boats and everything looked extra good in the clear light. He woke in the mornings now to the warmth of an almost noiseless gas heater; and the refrigerator, another example of Mem's earning power, although not new by some years, had nothing to do with the melted ice or spoiled food.

If he had done any of it himself, if he had insisted on the move, he might not have resisted the comfort, the feeling of doing better-ness with all his heart. $[\ldots]^{28}$

\footnotetext{
${ }^{28}$ Ibid. p.134-135. "Na casa da cidade, uma "mansão" de quatro cômodos com paredes de gesso, sem buracos, um quintal gramado e uma caixa de correspondência na varanda, ele permanecia em sua situação subalterna. Ele representava sua transformação pelo medo muito tempo depois do medo ter ido embora e ter sido substituído por uma grande vontade de expressar sua fúria, sua humilhação, seu ódio profundo. Durante o dia em seu trabalho em uma fábrica de tortas congeladas, ele ficava furioso com seu contentamento. Ele não achava justo que o novo trabalho fosse mais fácil do que ordenhar ou cultivar algodão ou milho. É verdade, havia o trabalho entediante de colocar as bandejas de tortas de pêssego na linha de produção, mas depois de vagar por anos atrás das vacas dos brancos, a monotonia o acalmou. $\mathrm{O}$ frescor constante do prédio quase o fez esquecer o calor sufocante do campo. Suas mãos eram mais secas agora, pois ele podia e usava luvas de borracha toda vez que havia trabalho úmido para realizar. Ele gostava de despejar a mistura para as tortas em grandes tonéis e gostava de regular os tubos de água dos caldeirões a vapor, e todo dia ansiava por lavar os grandes, brilhantes e sempre novos utensílios.

$\mathrm{Na}$ casa nova também havia uma sensação de progresso. Um banheiro interno com uma banheira branca, uma bacia, um espelho e um lavatório branco. Agora ele podia cagar e, ao se levantar, observar-se, ao modo como seus olhos haviam se livrado das detestáveis veias e linhas amarelas, sem muito odor ou chuva, e muito parecido com um cavalheiro; ou, como ele invariavelmente pensava, como um homem branco.

Ele foi forçado a manejar uma brocha em paredes sujas, a plantar arbustos, a tentar consertar a fiação defeituosa. Pois havia luz elétrica e ele às vezes era impelido a ler (olhar para as figuras) de catálogos que sua mulher recebia pelo correio. As fotos das roupas novas, das armas, dos barcos e tudo mais pareciam muito melhores sob a luz forte. Agora ele acordava de manhã com o calor de um aquecedor a gás quase silencioso, e o refrigerador, outro exemplo do poder financeiro de Mem, embora não fosse novo, não tinha nada a ver com gelo derretido ou comida estragada.

Se ele mesmo houvesse conquistado alguma coisa, se ele tivesse insistido em mudar, ele poderia não resistir ao conforto, ao sentimento de progresso com todo o seu coração [...] (Tradução minha)
} 
Em seu ressentimento acumulado e diariamente alimentado, Brownfield consegue fazer com que sua família perca todos os "confortos" conseguidos na cidade e volte a viver no campo em condições mais precárias ainda do que aquelas em que viviam antes da mudança. No quadro doméstico ele assume definitivamente o papel de "vilão" que não pode ser facilmente vencido por sua mulher, acabando por incorporar a maldade sádica, cruel e implacável de seus opressores.

Mem, por sua vez, trabalha cada vez mais para acumular e consumir, pois acredita piamente no valor utópico do capitalismo, que é a igualdade entre todos. Esta crença, aliada à visão puritana de que o trabalho engrandece o homem, faz com que ela reúna forças para trabalhar incansavelmente, até o dia de sua morte, para alcançar seu sonho.

$\mathrm{Na}$ verdade, ela é a figura da mulher inteligente e passiva, que assume toda a culpa da ruína de seu homem e, gradativamente, vê-se impelida a buscar sua independência, saindo do círculo vicioso da violência doméstica para o mundo do trabalho assalariado. Através dela, a autora registra a entrada da mulher negra no mundo do trabalho na forma mais humilhante e aterradora de todas, pois sua participação naquele mundo também é marcada pela submissão e pelo medo perpétuo.

Inserida neste contexto, ainda não se encanta com a idéia de lutar pela emancipação, mas sim pelas propagandas que anunciam as maravilhas de um novo estilo de vida, sempre associado ao consumo de mercadorias e ao conforto por elas proporcionado, como o recorte abaixo exemplifica:

[...] Daphne was looking at a page full of bathroom fixtures, staring nearly cross-eyed in the light of the kerosene lamp that hung from a cord over the table. 
"Is this the kinder toilet we going to have, Ma?" Ornette asked, looking dazzled over Daphne's sharp elbow at all the sparkling fixtures.

"Look at them shiny toilets!" she whispered urgently, her spread fingers touching four commodes, excitement making her voice rough and burpy. Daphne nudged her playfully with the elbow she kept between the Sears, Roebuck catalogue and her sister.

"Why don't you get on out the way, girl!" she said, and tried to hog the book, but Ornette clamped a grubby fist on a corner of the book, covering, except for a bright corner, deep white bathtub filled with greenish blue water like that in the white swimming pool in town. (grifo nosso)

Mem, her knees spread under the table and her battered hungry face cracking every once in a while in a grin, supervised the turning of the pages.

"Wait a minute, Daphne, I ain't through looking at these sinks and dishracks!" she said sharply, when Daphne wanted to race on ahead to the warming glowing pictures of multicolored light bulbs and fancy lamps.

"Is us going to have 'lectric lights in our new house? Ornette asked breathlessly, caressing the slick pages of the catalogue. [...]

"I ain't promising nothing," Mem said, laughing at Ornette's big serious eyes and running one rough hand over her head. "I ain't saying what's going to be," she continued, but the Lord wills we going to have "em!" She said the last flatly, almost to herself, hearing the back door open and shut and feeling the draft caused by Brownfield's entry and seeing the lamp flicker and almost go out. ${ }^{29}$

${ }^{29}$ Ibid. p.106-107. "Daphne estava olhando uma página repleta de acessórios para banheiro, os olhos arregalados, quase estrábicos, sob a luz de uma lâmpada de querosene que pendia de um fio em cima da mesa. "Este é o tipo de privada que nós vamos ter, mamãe? Ornette perguntava, olhando deslumbrada, por cima do cotovelo áspero de Daphne, para todos os acessórios brilhantes. "Veja as privadas brilhantes!" ela susurrava ansiosamente, seus dedos esticados tocando quatro lavatórios, sua voz grossa e rouca. Daphne a cutucava travessamente com o cotovelo que ela mantinha entre o catálogo da Sears, Roebuck e sua irmã. "Por que você não sai da frente, menina!" ela dizia, e tentava puxar o catálogo, mas Ornette segurava com força uma ponta do catálogo, cobrindo quase tudo, exceto uma banheira reluzente, de um branco profundo, repleta de água azul-esverdeada como aquela da piscina dos brancos na cidade. Mem, com as pernas esticadas por debaixo da mesa e seu rosto judiado e faminto cortado de vez em quando por um sorriso, supervisionava o virar das páginas. "Espere um pouco, Daphne, eu ainda não terminei de olhar estas pias e escorredores de louça!" ela dizia asperamente, quando Daphne queria ir rapidamente para as cálidas e reluzentes lâmpadas multicoloridas e sofisticados abajures. "Nós vai ter luz elétrica na nossa casa nova? Ornette perguntava ofegantemente, acariciando as páginas lisas do catálogo [...] "Eu não to prometendo nada," Mem dizia, rindo dos grandes olhos sérios de Ornette e passando uma 
Mãe e filhas sonham com um futuro promissor quando são chamadas à realidade pela chegada de Brownfield, amedrontador e repulsivo em seu papel de opressor, aprendido e assimilado ao longo dos vários anos de trabalho infrutífero.

A fronteira atravessada pelo personagem no processo de sua transformação de "herói” em "vilão" não é nítida, porém sua degeneração é claramente atribuída à elite branca americana, representada na narrativa por Mr. Shipley, Captain Davis e Mr. J. L., que espalham a crueldade e a injustiça a seu redor. O grau de corrupção moral, arrogância e decepções é o mesmo, ou pior, que dos seus opressores, com a diferença que os atos de violência de Brownfield são dirigidos contra sua própria gente.

Assim, o leitor acompanha a construção de um criminoso, vítima de um cenário imoral e desumano, comandado pela busca do poder financeiro e social, que transforma todos - brancos e negros - em "vilões modelares"; o branco, despótico, persuasivo, opressor de poder absoluto, e o negro, almejando o mesmo poder.

Conforme afirmado anteriormente, a trajetória da família Copeland é fortemente marcada pelas teorias de Frantz Franon acerca das relações colonizador/colonizado, e pelo movimento da História.

Segundo Fanon, em seu processo de descolonização os povos colonizados passariam por três fases. A primeira fase seria caracterizada pela aceitação, e pela tentativa de assimilação, da cultura do colonizador, o que implicaria em negação da cultura de origem do colonizado e acomodação às regras do jogo impostas pelo colonizador.

mão calejada em sua cabeça. "Eu não to dizendo como vai ser," ela continuava, mas o Senhor vai fazê a gente tê eles!" Ela disse as últimas palavras baixinho, quase para si mesma, ouvindo a porta dos fundos abrir e sentindo a corrente de ar causada pela entrada de Brownfield e vendo a lamparina tremeluzir e quase apagar." (Tradução minha) 
Brownfield e Mem situam-se claramente nesta fase; Mem aceita, sem questionamentos, a cultura do vencedor da elite branca norte-americana, e em nenhum momento enxerga a impossibilidade de alcançar tal ideal. Culpa o marido pelo fracasso material da família e pela desintegração de seu casamento, trabalha loucamente para mudar seu status social, até ser finalmente assassinada por Brownfield, derrotada por um sistema que não só a massacrou, mas também forjou a personalidade doentia e violenta de seu marido. Brownfield, por sua vez, no início da narrativa parece compreender sua posição na engrenagem da sociedade na qual está inserido e, por um breve período de sua juventude, tenta escapar. Porém, é facilmente vencido, e gradativamente vai aceitando e se acomodando às relações de poder até passar a viver de forma conflitante. Por um lado, acovarda-se diante do homem branco, culpando-o por suas desventuras, e acalenta a mesma revolta contida que percebia em seu pai Grange - quando ainda era uma criança. Por outro lado, incorpora o modelo de poder e de agressividade, volta-se contra a própria família e tem como sonho de vida ser igual a seu opressor.

A segunda fase tem como característica a negação total da cultura do colonizador e a afirmação absoluta da cultura do colonizado, promovendo uma tentativa de volta às raízes e às tradições da cultura do colonizado.

Grange Copeland, ao partir para o norte do país e viver em Nova Iorque, vive esta segunda fase, mas percebe não ser possível alcançar a estabilidade emocional e financeira apenas através da negação e da violência.

A terceira fase se caracteriza pela conscientização e conseqüente nacionalização da cultura, com seus traços peculiares, de forma a superar os estigmas das fases anteriores. 
Grange consegue alcançar esta fase, porém não da forma utópica como foi idealizada por Fanon, visto que, ao passar por todos esses processos, o colonizado terá uma cultura híbrida, fortemente marcada pela cultura do colonizador. Assim, ele retorna para o sul e tenta reconstruir sua vida através do isolamento e do afastamento da cultura do colonizador. No entanto, para que possa alcançar a tão sonhada "autonomia e autenticidade", é forçado a adequar-se ao sistema vigente, tornando-se um pequeno proprietário de terras, adquirindo bens de consumo e inserindo sua neta - Ruth - no sistema sócio-econômico norte-americano. Estas são as condições básicas para que ela possa ao menos tentar sobreviver inteira, como o avô quer.

Verifica-se, assim, que tal como Frantz Fanon a autora revela ingenuidade ao apresentar tal solução para as relações opressor/oprimido. Estas relações são altamente complexas, na medida em que têm uma dinâmica de funcionamento que não permite retroagir no tempo e apagar da memória as experiências vividas. $\mathrm{O}$ movimento da História sempre leva a caminhos diferentes daquele inicial, mesmo quando parece ser apenas uma réplica do mesmo.

Esta consideração remete à outra afirmação deste trabalho, segundo a qual Alice Walker constrói sua narrativa ancorada nas relações entre homem e História como definidas por Karl Marx.

Verifica-se, ao longo da narrativa, uma tentativa de reconstruir a história dos afro-descendentes através da trajetória de Grange Copeland. Não por acaso, o personagem e suas três vidas é escolhido para ser o eixo central do romance. Sua trajetória e sua convivência íntima com a neta em sua terceira vida assinalam uma maneira de construir um passado sobre o qual as futuras gerações de negros norteamericanos possam se assentar, se ver como um elo na cadeia de gerações, com a opção de repetir ou modificar comportamentos similares àqueles de seus ancestrais em 
determinadas situações a fim de alcançar a estabilidade emocional necessária para a construção do percurso de suas vidas. ${ }^{30}$

Partindo deste princípio, verifica-se que Grange tem uma tarefa de importância capital, já que terá que promover o remembramento da história de seu grupo étnico e, conseqüentemente, de sua família.

Apesar de ser a pessoa melhor qualificada para realizar este trabalho em função de sua vasta experiência pessoal, Grange só poderá realizá-lo dentro dos limites impostos pela própria História, nas condições estabelecidas pelo seu movimento.

Assim, ele deixa um legado a sua neta que, a princípio, daria a ela as condições necessárias para iniciar um ciclo novo de vida, livre dos sofrimentos experimentados por seus ancestrais.

Sua segurança econômica e emocional, porém, será bastante tênue e não será garantia de sucesso em sua caminhada. Afinal, Ruth é uma jovem negra - cujo pai assassinou a mãe e foi posteriormente morto pelo avô - que vive em uma sociedade profundamente preconceituosa, ancorada em valores construídos a partir da cultura branca européia, e dominada por homens.

Embora vá iniciar sua vida adulta em um momento profundamente marcado pelos acontecimentos envolvendo o Movimento pelos Direitos Civis, Ruth terá que viver no seio de uma sociedade que, na prática, não sofreu alterações radicais nas relações de gênero e raça. As chances de uma jovem negra e órfã, com uma história pessoal tão traumática, sobreviver inteira - como seu avô ambicionava - sem a necessidade de enfrentamentos que, com certeza, deixarão cicatrizes emocionais profundas, são muito pequenas.

\footnotetext{
${ }^{30}$ Afirmações feitas a partir da leitura de: SCHUTZENBERGER, ANNE A. Meus antepassados: vínculos transgeracionais, segredos de família, síndrome de aniversário e prática do genossociograma. São Paulo: Paulus, 1997. 215p.
} 
Certamente as condições que ela encontrará serão um pouco melhores que aquelas vividas por seus ancestrais, mas estarão muito longe da igualdade racial e social almejada por toda a comunidade negra de sua época. Some-se a isso o fato de que, estigmatizada em sua cidadezinha, Ruth só terá alguma chance de realização pessoal e econômica longe daquele lugar e esta parece ser sua constatação também. Nos capítulos finais do romance ela deixa entrever que partirá e sua empolgação com os jovens militantes do Movimento sugere que ela optará não só pelo abandono de sua cidade, mas também pela militância política.

A solução encontrada pela autora no desfecho de sua narrativa sugere que Ruth somente poderá sobreviver inteira na ficção, pois a realidade apresentada e discutida é altamente complexa e a possibilidade de transformação em curto prazo é praticamente inexistente.

Esta constatação nos remete diretamente a Fredric Jameson e sua afirmação de que "a narrativa é um ato socialmente simbólico que apresenta soluções formais ideais para problemas reais insolúveis." 31

O mérito de Alice Walker não está na sua proposta de tratamento das questões de raça e gênero, mas sim no trabalho de apresentação de uma realidade por ela mesma vivenciada. Sua narrativa, ao contrário dos romances tradicionais, foi construída através do ponto de vista de uma minoria massacrada econômica e socialmente; os fatos são apresentados sob a ótica do perdedor, e isto permite ao leitor adentrar um mundo desconhecido, de forma realista, observando os conflitos e as contradições de uma organização social excludente e em crise. Some-se a isso a relevância do tema tratado

\footnotetext{
31 JAMESON, F. A interpretação: A literatura como ato socialmente simbólico. In: O inconsciente político. São Paulo: Ática, 1992. 317 p.
} 
para o momento da publicação do romance: ano de 1970, período efervescente da história do movimento negro em busca de conquistas sociais e políticas.

\section{PONCIÁ VICÊNCIO}

Centrado na trajetória de vida da personagem que empresta seu nome ao título, o romance Ponciá Vicêncio caracteriza-se por uma narrativa fragmentada que promove uma articulação entre o presente e o passado através de recordações e devaneios.

Ponciá Vicêncio é neta de um ex-escravo, filha de um homem beneficiado pela Lei do Ventre Livre que, como tantos outros de sua origem, trabalha na lavoura juntamente com seu filho ainda menino. Enquanto pai e filho ficam dias distante de casa realizando seu trabalho, Ponciá e a mãe dedicam-se aos afazeres domésticos ao mesmo tempo em que moldam em barro utensílios e enfeites para a casa, para seu próprio uso e também para revenda nas regiões próximas.

Fora criada sozinha, só com a mãe. Tinha mais um irmão que pouco brincava com ela, pois acompanhava o pai no trabalho da roça, nas terras dos brancos. Ela e a mãe ficavam dias e dias sem ver os dois. Nos tempos das chuvas, as visitas deles rareavam mais ainda. A mãe 
fazia panelas, potes e bichinhos de barro. A menina buscava a argila nas margens do rio. Depois de seco, a mãe punha os trabalhos para assar num forno de barro também. As coisinhas saíam então duras, fortes, custosas de quebrar.

Ponciá Vicêncio também sabia trabalhar muito bem o barro. ${ }^{32}$

Alguns anos após a morte repentina do pai, Ponciá, ainda muito jovem, decide deixar o vilarejo onde vive - Vila Vicêncio - e partir para a "cidade grande" (não nomeada), onde pretende encontrar um trabalho que lhe permita ganhar dinheiro e comprar uma casa, para depois buscar a mãe e o irmão para morar com ela e iniciar um novo ciclo de vida. Ela se considera preparada para a empreitada, pois "aprendeu a ler e escrever".

Apesar das dificuldades iniciais, ela consegue um emprego como empregada doméstica: "Estava de coração leve, achava que a vida tinha uma saída. Trabalharia, juntaria dinheiro, compraria uma casinha e voltaria para buscar sua mãe e seu irmão. A vida lhe parecia possível e fácil.” (Evaristo, 2005, p. 42).

Assim motivada, Ponciá escrevia cartas, nunca respondidas pelos seus, e ia, às vezes, até a estação de trens, no dia em que o trem de carregamento que passava por Vila Vicêncio chegava, na tentativa de encontrar algum rosto conhecido que pudesse dar notícias. Muitos anos depois, finalmente encontra alguém que lhe informa que o irmão também havia partido para a mesma cidade e a mãe, desgostosa com a partida dos dois filhos, "largara tudo e saíra em busca não se sabe de quê. Dos filhos, do barro..." (Evaristo, 2005, p. 45)

Mesmo assim, quando conseguiu comprar um quartinho em um morro da periferia, Ponciá voltou para o povoado apenas para confirmar o que já sabia acerca da mãe e do irmão e constatar que os moradores que lá ficaram continuavam com a mesma

\footnotetext{
${ }^{32}$ EVARISTO, Conceição. Ponciá Vicêncio. Belo Horizonte: Mazza, 2005. 132 p. p. 18.
} 
vida de trabalho e desesperança. Voltou, então, para a cidade, onde conheceu um homem, trabalhador na construção civil, com o qual se casou.

Foi algum tempo antes destes acontecimentos que Ponciá começou a sentir “ausências":

\begin{abstract}
Nas primeiras vezes que Ponciá Vicêncio sentiu o vazio na cabeça, quando voltou a si, ficou atordoada. O que havia acontecido? Quanto tempo tinha ficado naquele estado? Tentou relembrar os fatos e não sabia como tudo se dera. Sabia apenas que, de uma hora para outra, era como se um buraco abrisse em si própria, formando uma grande fenda, dentro e fora dela, um vácuo com o qual ela se confundia. Mas continuava, entretanto, consciente de tudo ao redor. Via a vida e os outros se fazendo, assistia aos movimentos alheios se dando, mas se perdia, não conseguia saber de si. No princípio, quando o vazio ameaçava a encher a sua pessoa, ela ficava possuída de medo. Agora gostava da ausência, na qual ela se abrigava, desconhecendo-se, tornando-se alheia de seu próprio eu. ${ }^{33}$
\end{abstract}

O casamento de Ponciá fracassou, os sete filhos que teve morreram ao nascer, as crises de "ausência" tornaram-se cada vez mais freqüentes, ela abandonou o emprego e tornou-se uma mulher apática e uma dona de casa relapsa. Seu companheiro (que não tem nome), não consegue entender o que está acontecendo, não compreende porque aquela mulher "forte, arrojada e limpa" transformou-se em um ser alheio a tudo, não cuidando nem mesmo do miserável barraco em que viviam, transformando-o em um local sujo e triste. Em sua ignorância, acha que a única maneira de trazê-la de volta à realidade é através de "socos e murros". A reação dele inspira medo em Ponciá e a afasta mais ainda da realidade.

\footnotetext{
${ }^{33}$ Ibid. p. 44.
} 
Paralelamente, a narrativa apresenta a trajetória de seu irmão, Luandi José Vicêncio, que em sua vinda para a cidade consegue um emprego de faxineiro em uma delegacia de polícia.

Luandi tem por ídolo o soldado Nestor, negro como ele, e que, por isso mesmo, personifica a possibilidade de ascensão social. O grande sonho de Luandi é tornar-se um soldado também.

Assim como Ponciá, Luandi sai à procura da irmã pela cidade, volta para Vila Vicêncio na tentativa de encontrar a mãe e ter notícias da irmã e retorna sem informação alguma. Apenas deixa seu endereço com conhecidos na esperança que uma das duas, ou ambas, o encontrem. Trabalha com afinco, aprende a ler e escrever com o soldado Nestor, apaixona-se por uma prostituta que acaba sendo assassinada por seu gigolô e cai em uma tristeza profunda, abandonando-se a um torpor que o impede de reagir. É neste momento de sua vida que Luandi reencontra a mãe, Maria Vicêncio, através do amigo Nestor. O soldado estava de plantão na estação ferroviária quando observou...

[...] aquela mulher de andar temeroso, agarrada a uma pequena trouxa e que vinha na direção dele. Seu coração se alegrou, sem saber por que viveu a sensação de que, em todos seus anos de ofício, estava a esperar por ela. Não era a primeira vez que experimentava aquela sensação. Havia passageiros que, quando chegavam à cidade, era como se estivessem aportando no peito dele. No dia em que Luandi José Vicêncio chegou, ele já esperava por ele. Tinha sido num dia em que fora escalado para tirar serviço na estação, porque o outro soldado, o branco, se encontrava meio adoentado. E quando a mãe de Ponciá e de Luandi entregou ao soldado Nestor um papelzinho dobrado, quase rasgado pelo tempo e que ela cuidadosamente guardava enrolado num pedacinho de pano, entre os seios, ele sorriu reconhecendo a própria letra. Era como se previamente soubesse de tudo, pois tinha sido justo ele o autor daquela identificação que Luandi deixara um dia com Nêngua Kainda, para que a velha entregasse a sua 
mãe. Maria Vicêncio gostou daquele moço soldado que tinha idade para ser também seu filho.

Soldado Nestor pegou a trouxa da mulher, carinhosamente passou o braço pelos ombros dela e andaram até a delegacia. Estava feliz. Era como se ela fosse a sua mãe, que ele não via há tanto tempo. E como um filho que, ao reencontrar a mãe, sentia-se reencontrado, imaginava a alegria que Luandi iria viver. ${ }^{34}$

O reencontro com a mãe ajudou Luandi a se recuperar e realizar seu sonho de tornar-se soldado. Seu primeiro dia de trabalho na nova posição foi exatamente na estação ferroviária, lugar para onde Ponciá se dirigiu, seguida de longe pelo companheiro, quando a loucura se apoderou dela completamente.

Seu olhar escorregava de um ponto para o outro da pequena estação e eis que, de repente, capta a imagem de uma mulher que ia e vinha, num caminhar sem nexo, quase em círculo, no lado oposto em que ele se encontrava. E apesar de a estação ser pequena, a Luandi pareceu que uma distância de séculos se impunha entre ele e a mulhermiragem. Silhueta ao longe que demorava infinitamente a se concretizar diante dele. E sem conseguir dar um passo em direção ao que precisava alcançar, só a voz dele mexeu gritando um nome.

O nome de Ponciá Vicêncio ecoou na estação como um apito do trem e ela nem prestou atenção alguma ao chamado. Andava, chorava e ria, dizendo que queria voltar ao rio. Luandi acercou-se carinhoso da irmã, dizendo-lhe que sabia o caminho do rio e que haveria de levá-la. Ponciá Vicêncio levantou os olhos para ele, mas não se podia dizer se ela o havia reconhecido ou não. Abriu, porém, a trouxa, tirou o homem-barro e perguntou ao irmão se ele se lembrava de Vô Vicêncio. Ele, que até então, à custa de muito esforço, tinha o pranto preso, abraçou chorando a irmã.

\footnotetext{
${ }^{34}$ Ibid. p.119-120.
} 
E no seu primeiro dia de serviço, sem experimentar o gosto do mando, Soldado Luandi José Vicêncio, antes da hora terminada, deixou o posto de trabalho. Pegou a mão da irmã e foi com ela ao encontro da mãe. Boa hora, Maria Vicêncio andava muito aflita. $\mathrm{O}$ tempo pedia, era hora de encontrar a filha e levá-la novamente ao rio. 35

O reencontro da filha com a mãe, a família novamente reunida, a conscientização de Luandi, que aconteceu após o encontro com a irmã, e a loucura de Ponciá encerram a narrativa.

A história da família Vicêncio é apresentada de forma entrecortada, com o tempo presente sendo mesclado com o passado, revelado através de flashbacks proporcionados pelos devaneios de Ponciá. Esta escolha da autora, de exaltação da memória afetiva e histórica, revela o propósito de apresentar uma personagem em busca de explicações - pessoais, sociais e históricas - para os acontecimentos marcadamente negativos que ocorreram ao longo de sua vida, bem como daquela de seus familiares, e que forjaram sua personalidade e seu status social. Configura-se, assim, como uma forma de reflexão e denúncia dos mecanismos utilizados pela sociedade brasileira, através de séculos, para perpetuar as desigualdades raciais e sociais.

No parágrafo de abertura encontramos as características que darão o tom da narrativa: o ponto de vista interno, marcado por um discurso intimista que irá descrever a trajetória de Ponciá da infância à idade adulta. Uma trajetória que fala de sonhos, andanças, buscas e, principalmente, desencantos e perdas - da família, dos filhos, do amor, dos amigos, da esperança e, finalmente, da lucidez.

Os personagens - centrais e periféricos - não têm voz. A história de Ponciá e sua família é contada por um narrador onisciente que, além de transmitir ao leitor fatos,

\footnotetext{
${ }^{35}$ Ibid. p. 126-127.
} 
acontecimentos, sensações e sentimentos dos personagens, na maioria das vezes confunde-se com a mente deles, atuando como um porta-voz tanto dos seres ficcionais como das idéias da autora. ${ }^{36}$

Assim como na vida real, o grupo retratado não tem força nem representatividade para se posicionar social, política e culturalmente: em sua pobreza e privação não receberam sequer educação formal - que poderia se configurar como um elemento propulsor para o conhecimento e a reflexão, condições essenciais para uma intervenção transformadora - e apenas sobrevivem, inseridos em uma dinâmica de exploração e subserviência. São homens e mulheres excluídos dos mecanismos econômicos, políticos e sociais, esmagados pelas relações de poder que os circundam. Neste contexto, a dificuldade em verbalizar suas experiências, anseios e frustrações é uma conseqüência natural, simbolizada pela ausência de voz na narrativa.

A linguagem concisa, emotiva, comanda os sutis movimentos de intercâmbio entre o passado e o presente, delineando as diversas partes da narrativa que vão se intercalando de forma a acrescentar informações sobre pessoas e acontecimentos que, agrupadas, plasmarão o todo.

Este processo leva a uma fragmentação formal que é simbólica das rupturas e da conseqüente fragilidade psicológica que vai, lenta e inexoravelmente, se apoderando de Ponciá. É a arte decantando a vida através de uma estrutura que mimetiza a fratura social brasileira.

\footnotetext{
${ }^{36}$ Trabalhamos aqui com o conceito de autor-implicito de Wayne C. Booth: "Even the novel in which no narrator is dramatised creates an implicit picture of an author who stands behind the scenes, whether as stage manager, as puppeteer, or as an indifferent God, silently paring his fingernails. This implied author is always distinct from the "real man" - whatever we may take him to be - who creates a superior version of himself as he creates his work; any successful novel makes us believe in an "author" who amounts to a kind of "second self." This second self is usually a highly refined and selected version, wiser, more sensitive, more perceptive than any real man could be." BOOTH, W. C. Distance and point-of view. In: The theory of the novel. New York: The Free Press, 1967. p. 92.
} 


\subsection{A TRAJETÓRIA DE PONCIÁ}

[...] O importante na roça era conhecer as fases da lua, o tempo de plantio e de colheita, o tempo das águas e das secas. A garrafada para o mau da pele, do estômago, do intestino e para as excelências das mulheres. Saber a benzedura para o cobreiro, para o osso quebrado ou rendido, para o vento virado das crianças. $\mathrm{O}$ saber que se precisa na roça difere em tudo do da cidade. Era melhor deixar a menina aprender a ler. Quem sabe, a estrada da menina seria outra. ${ }^{37}$

Em outros tempos, a vida - ou certos aspectos da vida - e a natureza eram encantadas e, como tal, eram a fonte da magia da vida das pessoas. O processo civilizatório ocidental, conduzido pela ascensão do capitalismo, transfere o sentido da vida para o consumo e para a busca do sucesso econômico.

Sob esta perspectiva, dois pólos distintos norteiam a construção do romance Ponciá Vicêncio: o primeiro focaliza a transição do Império para a República e toda a complexidade de teorias que se fomentavam no final do século XIX, apontando os reflexos deste processo na massa embrutecida dos escravos e o abandono após a sua libertação como vítimas dos mandos e desmandos do processo de ensaio pré-capitalista. É neste contexto que aborda aspectos sobre o sentido da vida dominante naquela sociedade, demonstrando que a tão decantada liberdade na verdade reproduzia a escravidão presente na vida rural.

No segundo momento do processo, através da "educação", a heroína tenta romper a cadeia reprodutiva na qual está inserida, partindo em busca do sucesso

\footnotetext{
${ }^{37}$ EVARISTO, Conceição. Ponciá Vicêncio. Belo Horizonte: Mazza, 2005. 132 p. p. 25
} 
econômico na "cidade grande" onde continua tão vítima do sistema quanto antes. A mudança do campo para a cidade não altera seu status social, revelando ser enganoso o princípio de que o progresso econômico e a ascensão social seriam conseqüências naturais na vida daqueles que migravam.

\subsection{ESPAÇOS PERCORRIDOS}

Através das lembranças de Ponciá Vicêncio envolvendo seus ancestrais, Conceição Evaristo apresenta recortes que remontam a ação do romance ao final do século XIX - Brasil Império.

Dois fatores importantes da vida nacional naquele período merecem ser destacados: a sociedade brasileira convivia com o paradoxo gerado pela coexistência das idéias liberais - importadas da Europa e Estados Unidos da América - com uma economia fortemente assentada no regime escravocrata, ao mesmo tempo em que presenciava o desmonte do Império e o início do Brasil República, começando a sentir os ecos da modernidade que se instaurava e seus reflexos na escravidão. "Por sua mera presença, a escravidão indicava a impropriedade das idéias liberais; o que entretanto é menos que orientar-lhes o movimento.” (Schwarz, 1992, p. 15).

O advento da Abolição da Escravidão, gerada por interesses predominantemente econômicos, não veio alterar a ordem social brasileira. Ao fixarem os ex-escravos e seus 
descendentes na terra, os proprietários promoveram um desdobramento da ideologia do favor.

[...] pode-se dizer que a colonização produziu, com base no monopólio da terra, três classes de população: o latifundiário, o escravo e o "homem livre", na verdade dependente. Entre os primeiros dois a relação é clara, é a multidão dos terceiros que nos interessa. Nem proprietários nem proletários, seu acesso à vida social e a seus bens depende materialmente do favor, indireto ou direto, de um grande. $\mathrm{O}$ agregado é a sua caricatura. $\mathrm{O}$ favor é, portanto, o mecanismo através do qual se reproduz uma das grandes classes da sociedade, envolvendo também outra, a dos que tem. Note-se ainda que entre estas duas classes é que irá acontecer a vida ideológica, regida, em consequiência, por este mesmo mecanismo. Assim, com mil formas e nomes, o favor atravessou e afetou no conjunto a existência nacional, ressalvada sempre a relação produtiva de base, esta assegurada pela força. Esteve presente por toda parte, combinando-se às mais variadas atividades, mais e menos afins dele, como administração, política, indústria, comércio, vida urbana, Corte etc. Mesmo profissões liberais, como a medicina, ou qualificações operárias, como a tipografia, que, na acepção européia, não deviam nada a ninguém, entre nós eram governadas por ele. E assim como o profissional dependia do favor para o exercício de sua profissão, o pequeno proprietário depende dele para a segurança de sua propriedade, e o funcionário para o seu posto. O favor é a nossa mediação quase universal [... ${ }^{38}$

O recorte a seguir ilustra tal desdobramento:

"Há tempos e tempos, quando os negros ganharam aquelas terras, pensaram que estivessem ganhando a verdadeira alforria. Engano. Em muito pouca coisa a situação de antes diferia da do momento. As

\footnotetext{
${ }^{38}$ SCHWARZ, Roberto. As idéias fora do lugar. In; Ao vencedor as batatas. São Paulo: Liv. Duas
} Cidades, 1992. 169 p. p. 16. 
terras tinham sido ofertas dos antigos donos, que alegavam ser presente de libertação. E, como tal, podiam ficar por ali, levantar moradias e plantar seus sustentos. Uma condição havia, entretanto, a de que continuassem todos a trabalhar nas terras do Coronel Vicêncio. O coração de muitos se regozijava, iam ser livres, ter moradia fora da fazenda, ter as suas terras e os seus plantios." 39

"Disfarçando a violência, que sempre reinou na esfera da produção" (Schwarz, 1992, p.16), a nova ideologia instaurou um toque de "bondade e democracia" nas relações entre a aristocracia rural brasileira e seus subordinados. Os supostos homens livres de agora tinham a ilusão de estar recebendo todo o suporte necessário para a reconstrução de suas vidas, fato este que, a médio e longo prazo, poderia significar oportunidades de transformação para seus descendentes.

Este momento da História brasileira já sinaliza o despontar da ideologia da democracia racial, que seria abraçada calorosamente pela elite intelectual nas primeiras décadas do século XX.

Diferentemente do que ocorreu nos Estados Unidos da América, onde as relações raciais no período pós-Abolição foram gradativamente tornado-se mais violentas, preparando o terreno para um enfrentamento inevitável, em terras brasileiras o tratamento dado à questão foi muito mais eficiente. Ao "agregar" o negro à vida da Casa-Grande e ao uso da terra para fixar moradia e continuar trabalhando na lavoura, sob suas ordens, os proprietários criaram um mecanismo que impedia qualquer reação por parte da comunidade negra sob seu poder. Afinal, como rebelar-se contra seu benfeitor?

Esta forma inteligente e dissimulada de conduzir as relações raciais e sociais demonstrou ser extremamente eficaz e é visivelmente percebida na narrativa: na

${ }^{39}$ EVARISTO, Conceição. Ponciá Vicêncio. Belo Horizonte: Mazza, 2005. 132 p. p. 47. 
exposição das vidas que compõem o relato de Conceição Evaristo há muita injustiça, muito impasse e nenhum sinal de revolta social, revelando uma posição desagradavelmente conformista.

Assim, tem-se uma dívida infinita "que não se paga nem se cobra, o que de certa forma restabelece a dignidade do devedor. Não obstante, a verdade da gratidão no caso é a humilhação.” (Schwarz, 1992, p. 94) Humilhação de aceitar um fardo que não lhe cabe e não poder reivindicar aquilo que lhe é de direito.

É tão evidente o fato que apenas um personagem periférico, isolado, esboça uma reação livre e quebra o nexo da passividade que permeia as relações patrão (senhor) / empregado (escravo). Porém, apesar de verdadeira, a reação de Vô Vicêncio é desconsiderada, em função de sua insanidade mental:

A família de Ponciá recebeu um papelzinho daqueles. O Coronel chamou Vô Vicêncio, que já chorava e ria. O homem levou o papel à boca prendendo entre os dentes a bondade escrita do Coronel. E ali mesmo, na presença do doador, com o braço cotoco escondido nas costas, com a outra mão com gestos rápidos e raivosos rasgou tudo. $\mathrm{O}$ pai de Ponciá, naquela época, era ainda moço solitário de companheiros e mulher. Ela não era nem sonho ainda... Então, qual seria a herança que Vô Vicêncio havia deixado para Ponciá e que ela ouvia dizer desde menina? ${ }^{40}$

As reflexões de Ponciá Vicêncio sobre os destinos dos quilombolas que habitavam Vila Vicêncio, acompanham e exemplificam as insignificantes modificações ocorridas na ordem social. Ao apresentar as experiências vividas pelas famílias negras no período imediatamente posterior à Abolição da Escravidão, Conceição Evaristo

\footnotetext{
${ }^{40}$ Ibid. p. 61-62.
} 
descortina um referencial sobre o descumprimento da legislação vigente, registrando com precisão a falta de transparência social imposta pela herança do nexo colonial, dominado pelas relações de dependência.

Para alguns, coronel Vicêncio parecia um pai, um senhor Deus. O tempo passava e ali estavam os antigos escravos, agora libertos pela "Lei Áurea", os seus filhos, nascidos do "Ventre Livre"e os seus netos, que nunca seriam escravos. Sonhando todos sob os efeitos de uma liberdade assinada por uma princesa, fada-madrinha, que do antigo chicote fez uma varinha de condão. Todos, ainda, sob o jugo de um poder que, como Deus, se fazia eterno.

Depois de andar algumas horas, Ponciá Vicêncio teve a impressão de que havia ali um pulso de ferro a segurar o tempo. Uma soberana mão que eternizava uma condição antiga. Várias vezes seus olhos bisaram a imagem de uma mãe negra rodeada de filhos. De velhas e de velhos sentados no tempo passado e presente de um sofrimento antigo. Bisaram também a cena de pequenos, crianças que, com uma enxada na mão, ajudavam a lavrar a terra. ${ }^{41}$

O andamento da proposição é audacioso: busca ser uma voz a altura de seu tempo, problematizando a vida do país sem, no entanto, recorrer ao "pitoresco", que é uma forma fácil - e muitas vezes utilizada - de revestir as sérias questões sociais brasileiras de banalidade e tipificação. Evidencia o liberal escravismo paternalista, um dos aspectos dominantes da cultura brasileira, que disfarça a injustiça antiga - ainda presente - através de uma ilusória paisagem social de cordialidade e igualdade. A arbitrariedade, sempre presente através da dominação, é captada e sentida, mas nunca verbalizada, nem propulsora de um movimento de rebeldia.

\footnotetext{
${ }^{41}$ Ibid. p. 47-48.
} 
[...] Filho de ex-escravos, crescera na fazenda levando a mesma vida dos pais. Era pajem do sinhô-moço. Tinha a obrigação de brincar com ele. Era o cavalo onde o mocinho galopava sonhando conhecer as terras do pai. Tinham a mesma idade. Um dia o coronelzinho exigiu que ele abrisse a boca, pois queria mijar dentro. O pajem abriu. A urina do outro caía escorrendo quente por sua goela e pelo canto de sua boca. Sinhô-moço ria, ria. Ele chorava e não sabia o que mais lhe salgava a boca, se o gosto da urina ou se o sabor de suas lágrimas. Naquela noite teve mais ódio ainda do pai. Se eram livres, por que continuavam ali? Por que, então, tantos e tantas negras na senzala? Por que todos não se arribavam à procura de outros lugares e trabalhos? $[\ldots]^{42}$

O recorte acima, uma transposição que a autora faz da cena do menino Brás Cubas de Machado de Assis para a realidade vivenciada pelo pai de Ponciá quando ainda menino, revela a imutabilidade das relações de dominação bem como do sentimento de revolta não manifesto, não transformado em ação. Ao invés de reagir, o menino transfere para o pai, supostamente o "guardião" da família e, portanto, aquele que deveria protegê-lo, o ódio sentido pelo seu algoz.

Os flashbacks são reflexivos e reveladores, reenquadrando e presentificando o passado recente sob a perspectiva da dialética moral onde dinheiro e poder caminham juntos. Sob o manto do favor, relativizam a brutalidade e o descompromisso social, característicos das classes dominantes, que desde sempre souberam fazer uso deles de forma inteligente e coerente com os seus interesses.

Desde que os negros haviam ganho aquelas terras, ninguém tinha chegado e eles se casavam entre si. Eram parentes, talvez, desde

\footnotetext{
${ }^{42}$ Ibid. p. 14.
} 
sempre, desde lá de onde tinham saído. Ela decidiu, então, que iria rever os outros, aqueles que também eram os seus.

As casas das terras dos negros, para o olhar estrangeiro, eram aparentemente iguais. Chão batido, liso, escorregadio, paredes de paua-pique e cobertura de capim. As camas dos adultos e das crianças eram jiraus que os homens e mesmo as mulheres armavam com galhos de árvores amarradas com cipós. O colchão de capim era, às vezes, cheiroso, dado ao alecrim que se misturava ali dentro na hora de sua feitura. ${ }^{43}$

Paulatinamente, o narrador registra a transformação sofrida por Ponciá e os seus, decorrente da reprodução sistemática do mesmo quadro, que não se altera com os processos civilizatórios advindos do momento histórico vivido pelo país. A desigualdade, agora transformada, continua um fato, e a coisificação burguesa das relações sociais é colocada no centro do romance. Os fatos são intercalados, rememorados e recuperados, focando causas sociais e históricas.

Através da abordagem da exploração ainda existente na zona rural e do trabalho em regime de semi-escravidão assistimos a vagarosa transformação da ingênua menina pobre e negra em mulher revoltada, coisificada sob a luz do desenvolvimento capitalista.

Desde pequena, ouvia dizer também que as terras que o primeiro Coronel Vicêncio tinha dado para os negros como presente de libertação eram muito mais, e que pouco a pouco elas estavam sendo tomadas novamente pelos descendentes dele. Alguns negros, quando o Coronel lhes doou as terras, pediram-lhe que escrevesse o presente no papel e assinasse. Isto foi feito para uns. Estes exibiram aqueles papéis por algum tempo, até que um dia o próprio doador se ofereceu para guardar a assinatura-doação. Ele dizia que, na casa dos negros, o papel

\footnotetext{
${ }^{43}$ Ibid. p. 58-59.
} 
poderia rasgar, sumir, não sei mais o quê [...] os negros entregaram, alguns desconfiados, outros não. O Coronel guardou os papéis e nunca mais a doação assinada voltou às mãos dos negros. Enquanto isso, as terras voltavam às mãos dos brancos. Brancos que se fizeram donos desde os passados tempos. ${ }^{44}$

A segunda parte do romance quebra o fio da narrativa com a introdução de novos personagens, todos periféricos. Episódios díspares são narrados e não têm outro sentido senão o de justificar a proposição da autora, que é a de denunciar as arbitrariedades do poder em relação aos desfavorecidos, no caso específico, dos filhos e netos de escravos. São unidos à personagem principal apenas pelo mesmo senso de interesse.

A composição destes personagens não está revestida de grandiosidade; são mero pretexto para expor a transição do homem negro do campo para a cidade e o seu conseqüente destino permeado de ilusões e fracassos.

Estava calçado pela primeira vez. Na roça sempre andara de pés no chão. As luzes dos postes querendo tapear a escuridão da noite aborreciam profundamente o moço. "Para que eu vim pra cidade?", perguntou-se entre os dentes, resmungando, como era hábito de seu pai. "Para que eu vim pra cidade?", se perguntou novamente. Achar minha irmã, juntar dinheiro e ficar rico. É, ele havia de ficar rico. Diziam que na cidade as pessoas trabalham muito, mas ficam ricas. E de trabalho Luandi não tinha medo. ${ }^{45}$

Assim, da submissão contrariada dentro do mundo rural o personagem é transposto para o mesmo vínculo da dependência através do trabalho mal remunerado,

\footnotetext{
${ }^{44}$ Ibid. p.61-62.

${ }^{45}$ Ibid. p. 69.
} 
sempre por obséquio. Foi destino de sua irmã, será o destino de todos dentro deste mecanismo que não deixará alterar a ordem vigente, levando-os à cooptação e à impotência.

Guiado por suas qualidades morais, Luandi observa a nova realidade social com a qual passou a conviver na "cidade grande" e, silenciosamente, acalanta o natural desejo de ascensão que mais adiante se revelará pura ilusão. Não compreende ainda que nada é e nada será.

Ao limpar os últimos degraus da porta da delegacia, Luandi parou um pouco para permitir que o Soldado Nestor passasse. Luandi admirava o Soldado Nestor. Aquele era, para Luandi, maior que o escrivão, maior que o investigador, maior que o delegado, maior que Deus. Soldado Nestor era negro. Negro e soldado. ${ }^{46}$

Seu trabalho na cidade aparece como ruptura de sua condição subalterna no campo, que é tão bem evidenciada na única fala do personagem ao longo da narrativa, mostrando toda a sua inferioridade no linguajar de origem:

E foi com surpresa e sem entender até, que ele escutou o delegado dizer:

- Senhor Luandi José Vicêncio, o senhor está empregado! Empregado aqui na delegacia!

- Empregado? Como? Fazê o quê? Vesti farda, sê soldado? ${ }^{47}$

\footnotetext{
${ }^{46}$ Ibid. p. 68.

${ }^{47}$ Ibid. p. 71.
} 
A fala como expressão da desigualdade social não se apresenta como um fator de antagonismo, mas sim de coesão, ao mesmo tempo revelando os efeitos nocivos da subalternidade e dando um toque de "ingenuidade" ao personagem, toque este que evidencia a ignorância bem como a alienação. Luandi não tem consciência de que está submetido a um determinismo sócio-cultural que não só o imobilizará como também irá culpá-lo, mais adiante, pelo seu fracasso.

Em termos de composição romanesca, a apresentação de pequenos textos interdependentes, construídos em prosa econômica, revela o propósito de sugerir etapas de fatalidades nas vidas descritas. Levemente interligadas com o movimento da História brasileira, descortinam a fragilidade do progresso social e denunciam a força das relações de favor que obrigam o inferior a aceitar o inaceitável, fato este visível no conselho do "delegado branco" - símbolo do poder - ao "subalterno negro Luandi" após o assassinato de Bilisa:

Alguns dias, depois de tudo, o delegado mandou chamá-lo e, perto de
Soldado Nestor, falou do susto que o fato lhe causara. Nunca, em
tantos anos de trabalho, ele havia cuidado de um crime tão brutal
como aquele [....] E que Luandi não levasse a mal o que ele ia dizer,
mas quase todo negro era vagabundo, baderneiro, ladrão e com
propensão ao crime. Poucos, muito poucos, eram como o Soldado Nestor e ele. (grifo nosso) Soldado Nestor olhou desconsertado para Luandi $[\ldots]^{48}$

Em uma seqüência de fatos, ventilados superficialmente e que não colaboram para o desenvolvimento do enredo, a autora reúne uma representação problematizada da vida do país, colocando em foco as mazelas das diversas classes sociais brasileiras. Não

\footnotetext{
${ }^{48}$ Ibid. p. 120-121.
} 
se aprofundando na crítica e até se conformando com o quadro, que não convence o leitor, apresenta uma versão modernizada do paternalismo, como ilustrado a seguir:

Ponciá Vicêncio não queria mais nada com a vida que lhe era apresentada. Ficava olhando sempre um outro lugar de outras vivências. Pouco se dava se fazia sol ou se chovia. Quem era ela? Não sabia dizer. Ficava feliz e ansiosa pelos momentos de sua autoausência. Antes gostava de ler. Guardava várias revistas e jornais velhos. Lia e relia tudo. Época houve em que havia decorado notícias assim:

"Menino morre afogado na fossa" [...]

[...] "Pedreiro mata a mulher com quinze facadas" [...]

[...] "Mulher de deputado presa por atentado ao pudor" [...]

[...] "Desvio de verba na Prefeitura" [...]

Um dia Ponciá juntou todas as revistas e jornais e fez uma grande fogueira com tudo. De que valia ler? De que valia ter aprendido a ler? No tempo em que vivia na roça, pensava que, quando viesse para a cidade, a leitura lhe abriria meio mundo ou até o mundo inteiro. Agora nada lhe interessava mais nas notícias: o deputado podia morrer afogado na fossa, a mulher dele poderia dar trinta facadas nas costas do prefeito, o menino podia desviar verbas da prefeitura, o pedreiro podia ficar nu no carro trocando carícias com o outro deputado. O mundo podia virar de cabeça para baixo, que pouca diferença faria, que ela pouco se dava, que ela pouco se dava [...] ${ }^{49}$

No processo de articulação entre passado e presente, ainda nos primeiros capítulos, o leitor é informado da dificuldade de Ponciá em situar-se como indivíduo:

Ponciá Vicêncio gostava de ficar sentada perto da janela olhando o nada. Às vezes, se distraía tanto que até se esquecia da janta e, quando

\footnotetext{
${ }^{49}$ Ibid. p. 92-93.
} 
via, o seu homem estava chegando do trabalho. Ela gastava todo o tempo com o pensar, o recordar. Relembrava a vida passada, pensava no presente, mas não sonhava e nem inventava nada para o futuro. $\mathrm{O}$ amanhã de Ponciá era feito de esquecimento. Em tempos outros, havia sonhado tanto! Quando mais nova, sonhara até um outro nome para si. Não gostava daquele que lhe deram. Menina, tinha o hábito de ir à beira do rio e lá, se mirando nas águas, gritava o próprio nome: Ponciá Vicêncio! Ponciá Vicêncio! Sentia-se como se estivesse chamando outra pessoa. Não ouvia o seu nome responder dentro de si. Inventava outros. Panda, Malenga, Quieti, nenhum lhe pertencia também. Ela, inominada, tremendo de medo, temia a brincadeira, mas insistia. A cabeça rodava no vazio, ela vazia se sentia sem nome. Sentia-se ninguém. Tinha, então, vontade de choros e risos. ${ }^{50}$

Ponciá não consegue aceitar um nome que, como explicado mais adiante na narrativa, não deriva de sua família, mas sim daquela do proprietário das terras em que vive e que, antes, também foi o dono de seu avô: o coronel Vicêncio. Por outro lado, também não consegue encontrar outro nome para si.

Fruto de uma estrutura social que prima pela manutenção da dependência e da miséria como forma de garantir seus privilégios, Ponciá não consegue ajustar-se à ordem estabelecida. Sua relutância em aceitar um nome que não lhe pertence é simbólica da sua busca por uma nova forma de enquadramento social.

Ela é uma mulher sem nome, sem origem e, consequentemente, sem história. A adoção forçada do sobrenome do antigo proprietário das terras e de seus ancestrais induz a um estado de deslocamento, de quase suspensão. Neste processo, o sentimento de pertencimento a uma determinada família e a certa cultura, elementos importantes para a formação da personalidade do indivíduo, é escamoteado, resultando em fragilidade psicológica e conseqüente auto-estima baixa.

\footnotetext{
${ }^{50}$ Ibid. p. 16.
} 
Assim como Ponciá, Luandi também tem grande dificuldade em afirmar-se como indivíduo, com o agravante de não conseguir sequer situar-se como membro de uma classe social ou de um grupo étnico, como a passagem a seguir ilustra:

Por enquanto não era soldado ainda, estava apenas ensaiando, mas um dia chegaria em que ele haveria de ser um soldado verdadeiro. Desses que prendem e batem. Desses que vão à guerra. Podia tanto haver uma guerra...Uma guerra dos pretos contra os brancos? Uma guerra dos ricos contra os pobres? Ah, não! [...] Essas guerras não! Ele queria bater, prender... Se tivesse uma guerra dessas, de que lado ficaria? Ah! Só se fosse uma guerra dos bons contra os maus! Assim dava certo. Ele ficaria do lado dos bons, bateria nos maus, prenderia os perversos. 51

A busca de Ponciá e a indefinição de Luandi revelam sua subalternidade e alienação, solidamente erigidas através da força dos acontecimentos históricos e perpetuadas por modelos sociais culturalmente construídos. O pseudo progresso financeiro e social que buscam não está disponível para pessoas como eles.

[...] o progresso nacional repõe, isto é, reproduz e até amplia as inaceitáveis relações sociais da Colônia. E pior ainda, quando enfim suprime a escravidão, não é para integrar o negro como cidadão à sociedade livre, mas para enredá-lo em formas velhas e novas de inferioridade, sujeição pessoal e pobreza, nas quais se reproduzem outros aspectos da herança colonial, que teima em não se dissolver e parece continuar com um grande futuro pela frente, o qual é preciso reconhecer, ainda uma vez, como fundado na evolução moderna da economia. ${ }^{52}$

\footnotetext{
${ }^{51}$ Op. cit. p. $79-80$.

${ }^{52}$ SCHWARZ, R. Um seminário de Marx. In: Seqüências brasileiras. São Paulo: Companhia das Letras, 1999. p. 94
} 
Outra presença importante na narrativa é o personagem Vô Vicêncio. Logo nos capítulos iniciais o leitor é informado que Ponciá Vicêncio havia herdado algo do avô. A herança não é especificada, mas somos informados que o avô havia enlouquecido após assassinar a mulher e decepar parte do braço, depois de ter quatro filhos, nascidos já na vigência da Lei do Ventre Livre, vendidos pelo seu senhor.

O primeiro homem que Ponciá Vicêncio conhecera fora o avô. Guardava mais a imagem dele do que a do próprio pai. Vô Vicêncio era muito velho. Andava encurvadinho com o rosto quase no chão. Era miudinho como um graveto. Ela era menina, de colo ainda, quando ele morreu, mas se lembrava nitidamente de um detalhe: em Vô Vicêncio faltava uma das mãos e vivia escondendo o braço mutilado pra trás. Ele chorava e ria muito. Chorava feito criança. Falava sozinho também. O pouco tempo em que conviveu com o avô, bastou para que ela guardasse as marcas dele. Ela reteve na memória os choros misturados aos risos, o bracinho cotoco e as palavras não inteligíveis de Vô Vicêncio. Um dia ele teve uma crise de choro e riso tão profunda, tão feliz, tão amarga e desse jeito se adentrou pelo outro mundo. ${ }^{53}$

Seu andar curvado, seu corpo mutilado e sua loucura, são seqüelas impressas em uma pessoa submetida às forças do sistema escravocrata brasileiro. No caso de Vô Vicêncio, assim como dos demais indivíduos em situações correlatas, os danos foram tão graves que atingiram as gerações seguintes, representadas pelo filho - pai de Ponciá - e pelos netos - Ponciá e Luandi. A transferência para a família da violência com que é tratado pela sociedade alimenta um círculo vicioso que se perpetua através de relações sórdidas nas quais o "ganhador" ganha sempre mais e o "perdedor" também perde

\footnotetext{
${ }^{53}$ EVARISTO, Conceição. Ponciá Vicêncio. Belo Horizonte: Mazza, 2005. 132 p. p. 12.
} 
sempre mais. Um moto-perpétuo que responsabiliza totalmente o fraco por sua fraqueza.

O filho consegue apenas reproduzir a vida de muito trabalho e exploração do pai, com o agravante de carregar uma revolta contida contra o homem que matou sua mãe e que não conseguiu conquistar nada melhor para os seus. Ponciá, assim "como o avô, foi acumulando partidas e vazios até culminar numa grande ausência." (Barbosa, 2005, p. 5), e Luandi desenvolveu o ideal de alcançar o poder, que para seus horizontes se resumia em ser soldado para "mandar e bater" nas pessoas e, assim, sentir-se respeitado. Seu modelo é o homem branco, símbolo de autoridade e dominação. Foi somente depois de ter a namorada assassinada, presenciar a loucura da irmã e a fragilidade da mãe que ele conscientizou-se de sua impotência diante de um sistema sócio-econômico, político e cultural forjado de forma a manter os mais fracos à margem, ao mesmo tempo em que acena com possibilidades enganosas de sucesso.

E ele que queria tanto ser soldado, mandar, bater, prender, de repente descobria de que nada valia a realização de seus desejos, se fossem aqueles os sentidos de sua ação, de sua vida. Soldado Nestor era tão fraco e tão sem mando como ele. Apenas cumpria ordens, mesmo quando mandava, mesmo quando prendia. Foi preciso que a herança de Vô Vicêncio se realizasse, se cumprisse na irmã para que ele entendesse tudo. ${ }^{54}$

Sob esta ótica, é bastante interessante a descrição que Ponciá faz de sua casa:

Fechou os olhos e relembrou a casinha de chão de barro batido de sua infância. $\mathrm{O}$ solo era todo liso e por igual, mesmo seco dava a

\footnotetext{
${ }^{54}$ Ibid. p. 130.
} 
impressão de ser escorregadio. Tudo ali era de barro. Panelas, canecas, enfeites e até uma colher com que a mãe servia o feijão. ${ }^{55}$

Assim como o chão e os utensílios, os moradores daquela casa também foram "feitos de barro". O material é barato, resistente e frágil ao mesmo tempo, e assim foi moldada a família Vicêncio: oriundos do campo, pobres e negros - fato este que no Brasil praticamente se configura como um pleonasmo - determinados e "bem intencionados", tentaram transformar suas vidas, mas foram vencidos por uma força maior, que os quebrou.

\subsection{O BARRO}

Ao longo da narrativa há referências constantes aos objetos de barro, vistos também como formas de arte, sendo que o destaque maior de sua presença é o boneco/Vô Vicêncio feito por Ponciá quando ainda menina. Seu uso pela autora permite diferentes digressões.

O barro remete a uma forma de vida primitiva, vinculada à sociedade camponesa, cuja rotina de trabalho e concepção de mundo era fortemente associada aos ciclos no tempo, às estações do ano, enfim, à vida regida pela natureza e com ela compartilhada. Do ponto de vista metafísico o barro é, ao mesmo tempo, terra, água, ar

\footnotetext{
${ }^{55}$ Ibid. p. 22.
} 
e fogo. Seu processo de transformações pode ser comparado aos ciclos da vida “Comerás teu pão com suor de teu rosto, até que voltes à terra, porque foste tomado dela; porquanto és pó, e ao pó voltarás." (Gênesis, capítulo 3, versículo 19). Seu manuseio, que provoca o contato com seu cheiro, sua textura, plasticidade e flexibilidade, desperta sensações que remetem o indivíduo às suas origens, às raízes que promovem sua sustentação e estrutura emocional. Na esteira desse processo vem a sensação de poder criar, de poder dialogar com o mundo interno e produzir frutos que reflitam um estado de espírito, uma visão de mundo.

Sob essa perspectiva, justifica-se sua presença constante na trajetória de Ponciá Vicêncio: ao deixar sua vida de menina do campo e mudar-se para a cidade, ela rompe com a estrutura da sociedade agrária e tenta se integrar à sociedade industrial, onde sua habilidade de trabalhar com o barro cede espaço à sua transformação em mão-de-obra barata. Seu trabalho como empregada doméstica não exige atributos especiais e acaba por adormecer suas habilidades no manuseio do barro. Absorvida e massacrada pela nova vida na "cidade grande", vai vagarosamente enlouquecendo ao mesmo tempo em que, vagarosamente, o desejo de trabalhar com o barro vai retornando. Já tomada pela loucura, prepara-se para voltar ao campo e ao trabalho artesanal. “[...] porquanto és pó e ao pó voltarás": tanto em termos religiosos quanto em termos sociais ela não é nada, daí a necessidade de voltar à essência da vida, à relação fundamental e recíproca com a terra.

Não muito longe dali, num salão de um clube, estava montada uma exposição de arte popular [...]

E com o olhar inebriado com tudo o que via, Luandi se encontrava e se perdia em meio aos trabalhos da exposição. Mal podia caminhar adiante. Parava demoradamente o olhar em cada objeto, embora, 
aflito, necessitasse da próxima mesa. Foi quando, para o seu próprio susto e de Soldado Nestor, ele se apoderou carinhosamente de uma canequinha de barro e com a voz embargada, quase em choro, gritava: "É minha, é minha." E, feito criança, bulia em tudo chamando pela mãe e por Ponciá, desconhecendo as recomendações sussurradas de Soldado Nestor, que lhe tomava os trabalhos tentando recompor a exposição. E, sem que Luandi pedisse, o amigo, também emocionado, pegou o cartãozinho branco que estava ao lado dos objetos e leu:

"Autores: Maria Vicêncio e filha Ponciá Vicêncio"

Região: Vila Vicêncio

Proprietário: Dr: Aristeu Pena Forte soares Vicêncio.

Luandi olhava os trabalhos da mãe e da irmã como se os visse pela primeira vez, embora se reconhecesse em cada um deles. Observava as minúcias de tudo. Havia os objetos de uso: panelas, potes, bilhas, jarros e os de enfeites, em tamanho menor, pequeníssimos. Pessoas, animais, utensílios de casa, tudo coisas de faz-de-conta, objetos de enfeitar, de brincar. Criações feitas, como se as duas quisessem miniaturar a vida, para que ela coubesse e eternizasse sobre o olhar de todos, em qualquer lugar. ${ }^{56}$

O envolvimento de mãe e filha com a produção artesanal de objetos de barro, seja para uso doméstico ou para a comercialização - junto à vizinhança - de enfeites para a ornamentação das moradias, também remete à realidade sócio-cultural de uma vasta camada da sociedade brasileira. Partindo de necessidades básicas - no caso, utensílios para a casa - que não podem ser supridas com a simples compra dos objetos em função de seu baixíssimo poder aquisitivo, buscam uma matéria prima que possa ser extraída da própria natureza local, portanto gratuitamente, para solucionar um problema imediato. Esse lidar, "brincar" com o material, gradativamente induz a manifestações artísticas da vida simples e rústica, que por sua vez acaba por viabilizar uma nova fonte de renda através da venda dos objetos produzidos. Exemplos dessa dinâmica são

\footnotetext{
${ }^{56}$ Ibid. 105-7.
} 
encontrados principalmente no artesanato oriundo do interior do norte e nordeste do Brasil, produtores de "uma vasta cerâmica, bruta e selvagem, a utilitária na forma e material, e a decorativa, no absurdo dos animais esboçados, verdadeiros exemplares de arte primitiva." (Xavier, 1994, p. 55)

Sob outro ângulo, o trabalho das personagens de Ponciá Vicêncio com o barro sugere uma ligação com as digressões de Alice Walker acerca da criatividade reprimida das mulheres negras. Segundo a escritora, em seu envolvimento com o trabalho e a busca constante de formas de subsistência ou até mesmo de sobrevivência de sua prole, muitas de suas ancestrais viviam como que anestesiadas, sem tempo para compreender ou mesmo procurar as qualidades artísticas que carregavam consigo.

Black women are called, in the folklore that so aptly identifies one's status in society, "the mule of the world," because we have been handed the burdens that everyone else - everyone else - refused to carry. We have also been called "Matriarchs", "Superwomen", and "Mean and Evil Bitches". Not to mention "Castraters" and "Sapphire's Mama". When we have pleaded for understanding, our character has been distorted; when we have asked for simple caring, we have been handed empty inspirational appellations, then stuck in the farthest corner. When we have asked for love, we have been given children. In short, even our plainer gifts, our labors of fidelity and love, have been knocked down our throats. To be an artist and a black woman, even today, lowers our status in many respects, rather than raises it: and yet, artists we will be. ${ }^{57}$

\footnotetext{
${ }^{57}$ WALKER, Alice. In search of our mothers' gardens. In: In search of our mothers' gardens. New York: Harcourt Brace, 1984. 397 p. P. 237. "As mulheres negras são chamadas, no folclore que tão apropriadamente identifica o status na sociedade, "as mulas do mundo," porque nos foi entregue os fardos que todos os demais - todos os demais - se recusaram a carregar. Nós também fomos chamadas de "Matriarcas", "Supermulheres", e "Cadelas sórdidas e perniciosas". Sem mencionar "Castradoras" e "A mãe de Safira". Quando pleiteamos compreensão, nosso caráter foi desvirtuado; quando pedimos carinho, nos entregaram nomes vazios, depois fomos jogadas no canto mais distante. Quando pedimos amor, deram-nos filhos. Em resumo, até nossos dons mais ordinários, nossos trabalhos de fidelidade e amor, foram enfiados em nossas gargantas. Ser uma artista e uma mulher negra, mesmo hoje, reduz nosso status em muitos aspectos, ao invés de elevá-lo: e mesmo assim, artistas nós seremos.” (Tradução minha)
} 
Neste contexto, o cultivo de jardins que produziam flores para adornar suas moradas simples e rústicas - como Mem faz em The third life of Grange Copeland -, a confecção de colchas de retalhos, a garantia de continuidade de histórias de família ou de contos africanos através do contar de histórias e até o cantar aos domingos nas igrejas, podem ser definidos como manifestações artísticas. Tais manifestações cumpriam o duplo papel de abastecer a casa e a família com objetos que supriam suas necessidades básicas e também de ser uma válvula de escape, uma forma de aliviar as tensões vividas no cotidiano.

Ao apresentar o trabalho com a argila como a única atividade não esquecida por Ponciá Vicêncio quando a loucura se apodera dela, Conceição Evaristo promove um ponto de encontro com as concepções feministas apresentadas e discutidas por Alice Walker em seus ensaios e romances.

O posicionamento feminista de ambas as autoras reflete duas percepções: a primeira é aquela relativa à posição da mulher, via de regra branca, na sociedade patriarcal ocidental e capitalista, que a posiciona e usa de acordo com as necessidades históricas e econômicas. Assim, ela transita de um momento (como acontecia nos séculos XVIII, XIX e na década de 50 do século XX) em que é considerada o "esteio" da família nuclear - cuidando da casa e das necessidades e demandas do marido e dos filhos, atuando de forma a manter o "equilíbrio familiar" - para um outro momento (durante a Segunda Guerra Mundial, por exemplo) em que seu trabalho é requerido para atender as forças produtivas através do trabalho fora de casa, a princípio desqualificado - em fábricas ou como empregadas domésticas - e depois em áreas mais especializadas, porém com um salário inferior àquele pago aos homens que exercem as mesmas 
funções, ou em profissões consideradas femininas - professoras, enfermeiras, psicólogas, etc. - e, portanto, percebendo salários menores.

A segunda percepção - e também a mais complicada - é aquela da mulher negra, duplamente discriminada em função de seu sexo e sua cor, e sofredora de uma opressão maior ainda em função de seu pertencimento à camada dos marginalizados da sociedade: negras e, na grande maioria dos casos, pobres. Mulheres, pobres e negras: uma combinação perfeita para o exercício da exclusão social.

Tanto Alice Walker quanto Conceição Evaristo são oriundas desta camada social em seus respectivos países: Walker é filha de lavradores do sul dos Estados Unidos da América e Evaristo nasceu e foi criada em uma favela de Belo Horizonte. São artistas que procuram, com seus romances, retratar a realidade dessas mulheres através da exposição e análise de seus relacionamentos familiares e sociais. Suas origens as credenciam a apresentar fatos e reflexões de quem vivenciou a complexidade do mundo dos perdedores, denunciando a atmosfera desolada e carente que as cercou durante grande parte de suas vidas. Ao mesmo tempo, procuram demonstrar, de maneira muitas vezes simbólica, os percalços e a solidão de mulheres que, como elas, aventuram-se no caminho da arte.

The most disturbing incident in the novel, the brutal murder of a woman and mother by her husband and the father of her children, is unfortunately based on a real case, In my small hometown of Eatonton, Georgia, there was when I was growing up, and there still is now, an incredible amount of violence. "Eatonton is a violent little town", is what is said by the locals when all other attempts to explain some recent disaster have proved useless. The black people there, as in so many parts of the world, are an oppressed colony, and as one of our great African-American writers has said (and I paraphrase), in their frustration and rage they of course kill each other. But what, I 
wondered, would happen if you could show the people in the oppressed colony the futility of this? In any case, perhaps the violence of my hometown was impressed upon me even more than upon many others because I visited the local black funeral home several times a week. I had a job as babysitter right next door, and my sister worked in the funeral home itself, as beautician and cosmetologist. On one side of the hall she shampooed, pressed and curled the hair of the living, on the other side she did the same for countless cadavers; she also made up their faces and sometimes their bodies, covering bruises, cuts, gunshot wounds, scratches and tears as best she could with her magic tricks arsenal of assorted powders and paints.

But even she was unable to do much for the victim around whose demise this story is built. Needing to share her frustration and, I assumed, outrage (we never discusses how she felt), she invited me into the room where Mrs. Walker (same last name as ours) lay stretched on a white enamel table with her head on an iron pillow. I describe her in the novel exactly as she appeared to me then. Writing about it years later was the only way I could be free of such a powerful image. Still, I see it; not so much the shattered face - time has helped to erase the vividness of that sight - but always and always the one calloused foot, the worn, run-over shoe with a ragged hole, covered with newspaper, in its bottom.

Another irony: Mrs. Walker's daughter was one of my classmates. Her name was Kate. Was this not the name of my own grandmother, also shot to death by a "lover"? And who, in whispered family conversations, was somehow blamed for this? [...]

[...] In my immediate family too there was violence. Its roots seemed always to be embedded in my father's need to dominate my mother and their children and in her resistance (and ours), verbal and physical, to any such domination. Discussing this with my husband, who came from a different culture entirely (or so I thought) from mine, I discovered there had also been precisely the same kind of violence in his family. Seeing the dead body of Mrs. Walker there on the enamel table, I realized that indeed, she might have been my own mother and that perhaps in relation to men she was also symbolic of all women, not only including my husband's grandmother and mother, who were as different from my own, I had thought, as possible, but 
also of me. That is why she is named Mem, in the novel, after the

French la meme, meaning "the same", ${ }^{58}$

\subsection{A FAMÍLIA VICÊNCIO E O BRASIL}

\footnotetext{
${ }^{58}$ WALKER, Alice. Afterword. In: WALKER, Alice. The third life of Grange Copeland. New York: Harcourt Books, 2003. 318 p. P. 315 - 316. "O incidente mais perturbador do romance, o assassinato brutal de uma mulher e mãe por seu marido e pai de seus filhos, é infelizmente baseado em um caso real. Em minha pequena cidade de Eatontown, havia, quando eu era pequena, e ainda existe, muita violência. "Eatontown é uma cidadezinha violenta", é o que é dito pelos moradores quando todas as outras tentativas de explicar um desastre recente provam inúteis. Os negros lá, assim como em muitas partes do mundo, são uma colônia oprimida e, como um de nossos maiores escritores afro-americanos disse (e eu o parafraseio) em sua frustração e raiva é claro que eles se matam. Mas o que, eu me perguntava, aconteceria se você pudesse mostrar às pessoas da colônia oprimida a futilidade disso? De qualquer modo, talvez a violência da minha cidade natal tenha me impressionado mais do que muitos outros porque eu visitava a funerária local dos negros várias vezes por semana. Eu trabalhava como babá em uma casa ao lado, e a minha irmã trabalhava na própria funerária como maquiadora e cabeleireira. Em um lado do hall ela lavava, secava e encaracolava o cabelo dos vivos e do outro ela fazia o mesmo com incontáveis cadáveres. Ela também reconstruía seus rostos e às vezes seus corpos, cobrindo hematomas, cortes,ferimentos a bala, arranhões e lágrimas o melhor que podia com seu arsenal de truques mágicos com muitos pós faciais e pinturas. Mas mesmo ela foi incapaz de fazer muito pela vítima sobre cuja morte esta história é construída. Precisando compartilhar sua frustração e, eu presumo, ultraje (nós nunca falamos sobre como ela se sentia) ela me levou para a sala onde a Senhora Walker (mesmo sobrenome que o nosso) jazia esticada em uma mesa branca esmaltada, com a sua cabeça em um travesseiro de ferro. Eu a descrevo no romance exatamente como eu a vi na época. Escrever sobre isso anos depois foi a única maneira de me libertar de uma imagem tão forte. Eu ainda vejo, não tanto o rosto destroçado - o tempo me ajudou a apagar a intensidade daquela visão - mas sempre e sempre o pé calejado, o sapato velho, esfarrapado, com um buraco na sola, forrado com jornal.

Outra ironia: a filha da Senhora Walker era uma de minhas colegas de classe. Seu nome era Kate. Não era esse o nome da minha avó, também morta a tiros por um "amante"? E quem, em sussurradas conversadas familiares, era de alguma forma culpada por isso? [...] Em minha família próxima também havia violência. Suas raízes pareciam estar sempre embutidas na necessidade do meu pai de dominar minha mãe e seus filhos e na resistência dela (e nossa), verbal e física, contra qualquer tipo de dominação. Discutindo isso com meu marido, que vem de uma cultura totalmente diferente (ou assim eu pensava) da minha, eu descobri que havia existido precisamente o mesmo tipo de violência na família dele. Vendo o cadáver da Sra. Walker sobre a mesa esmaltada, eu percebi que na verdade ela poderia ter sido minha própria mãe e que talvez em relação aos homens ela era também simbólica de todas as mulheres, não só incluindo a avó e a mãe do meu marido, que eram tão diferentes da minha, eu pensava, quanto possível, mas também de mim. É por isso que o nome dela é Mem, no romance, derivado do francês La meme, significando "a mesma." (Tradução minha)
} 
Em termos temporais, a trajetória de Ponciá Vicêncio alinha-se com o nacional desenvolvimentismo brasileiro nos anos 60 e 70 do século XX:

No limite tratava-se de arrancar a população aos enquadramentos semicoloniais em que se encontrava, e de trazê-la, ainda que de forma precária, ao universo da cidadania, do trabalho assalariado e da atividade econômica moderna, industrial sobretudo, contrariando o destino agrário a que o imperialismo - como se dizia - nos forçava (o que aliás naqueles anos 60 deixara de ser verdade). Isso na ótica justificadora e como que "responsável" do projeto nacional. Com menos simpatia e mais acento na irresponsabilidade e na cegueira, pode-se dizer igualmente que os novos tempos desagregavam à distância o velho enquadramento rural, provocando a migração para as cidades, onde os pobres ficavam largados à disposição passavelmente absoluta das novas formas de exploração econômica e de manipulação populista. ${ }^{59}$

Assim como para o nacional desenvolvimentismo, todas as projeções otimistas para o futuro construídas pela família Vicêncio foram destruídas. Deslocaram-se do interior para a metrópole - rompendo seus laços com o trabalho agrícola - em busca da modernidade, do progresso e da ascensão social, alimentados por um otimismo ingênuo que não resistiu ao contato com a realidade que encontraram. No processo de transição de membros da cultura agrária para membros da cultura urbana enfrentaram situações de privação e exclusão que nada mais fizeram do que corroborar seu status de mão-deobra desqualificada não absorvida e, portanto, massacrada pelo sistema. São personagens esquecidos da história que apenas vivenciaram - sob uma nova roupagem o ciclo de submissão, exploração e pobreza no qual estavam inseridos anteriormente.

\footnotetext{
${ }^{59}$ SCHWARZ, R. Fim de século. In: Sequiências brasileiras. São Paulo: Cia das Letras, 1999. 249 p. p. 156.
} 
Restou apenas a constatação de que a realidade social e econômica continuava a mesma, levemente maquiada com alguns toques de modernidade.

Sob esta ótica, podemos afirmar que o romance é nutrido por um realismo alegórico que remete à história do próprio país. Ponciá Vicêncio e sua família são legítimos representantes do Brasil - principalmente aquele Brasil que abriga milhões de indivíduos paupérrimos, mantidos à margem da sociedade - e a derrota final da personagem principal, imersa na loucura, coincide com o desapontamento generalizado causado pelo fracasso do projeto de desenvolvimento nacional.

[...] é interessante notar que a realidade começava a se parecer com a filosofia, no caso, com a terra movediça postulada pelo desconstrucionismo. O processo de modernização, com dinamismo próprio, longo no tempo, com origens e fins mais ou menos tangíveis, não se completou e provou ser ilusório. Nessas circunstâncias, a desestabilização dos sujeitos, das identidades, dos significados, das teleologias - especialidades enfim do exercício de leitura pósestruturalista - adquiriu uma dura vigência prática. Assim, o desenvolvimento nacional pode não ter sido nem desenvolvimento nem nacional, muito menos uma epopéia. ${ }^{60}$

Vale ressaltar a situação política do país naquele período, cuja inserção no romance certamente o enriqueceria. $\mathrm{O}$ projeto de desenvolvimento nacional aconteceu em uma época em que o Brasil vivia a fase mais intensa da Ditadura Militar instaurada com o Golpe de 1964. Foi o momento em que foi promulgado o famigerado Ato Institucional $n^{o} 5(A I-5)$, seguido pela posse do general Emilio Garrastazu Médici, que governou o país por cinco anos sob literal estado de sítio, com censura rigorosa à imprensa, ao rádio e à televisão. Foi no seu governo, também, que a repressão aos focos

\footnotetext{
${ }^{60}$ Ibid. p. 158.
} 
de resistência foi mais cruel e violenta, com a tortura e o assassinato de milhares e milhares de jovens, em sua grande maioria estudantes, comandada pelos DOI-CODIs órgãos de repressão que tinham em suas fileiras membros das Forças Armadas e da Polícia e que tinham autonomia de ação muito grande.

Os personagens de Conceição Evaristo vivem aquele momento, porém não o registram, e com isso fica perdida a oportunidade de se elencar uma série de considerações político-econômicas que contribuíram para explicar seu desterro.

\subsection{OS HOMENS E A FAMÍLIA}

O tratamento dado aos homens por Conceição Evaristo difere muito daquele dado por Alice Walker. Em Ponciá Vicêncio os homens são retratados como pessoas frágeis e impotentes diante da violência imposta pelo sistema. Sua reação à realidade que os cerca é a passividade e, quando cometem um ato de violência, é por absoluta ignorância e com a intenção de ajudar. Invariavelmente são homens que falam pouco, tão oprimidos e sofridos que não conseguem sequer verbalizar seus sentimentos. São tão vítimas das circunstâncias quanto as mulheres.

[...] O pai de Ponciá não era dado a muitos risos, caladão, quieto, guardava para si os sentimentos. Quando menino, não. Apesar dos mandos do sinhozinho e da aparente obediência cega, que era obrigado a demonstrar, ele revelava as suas tristezas com imensas 
lágrimas, assim como gritava alto os seus risos. Entretanto, foi crescendo e aprendendo a disfarçar o que lá de dentro vinha. Não chorava e também guardava o riso. E o máximo que fazia, se descontente estava, era resmungar, mas tão baixinho e com os lábios tão cerrados, que os resmungos caíam para si próprio, numa discordância funda e nula. ${ }^{61}$

A diferença entre o comportamento animalesco de Brownfield, criado por Alice Walker, e o comportamento do companheiro de Ponciá é gritante. O segundo, quando foi violento, o fez apenas movido pelo amor à companheira e arrependeu-se ao perceber seu erro. A sua maneira, sempre tentou ser carinhoso.

O homem de Ponciá Vicêncio cutucou de mansinho o ombro dela e lhe acenou com a canequinha de café. Um cheiro bom invadiu o ar. Ela olhou para ele assustada, fazendo menção de se levantar. O homem impediu-a, tocando agora de leve o seu rosto. Ela teve um ligeiro tremor de medo. Ele iria bater-lhe novamente? Arregalou os olhos, curvou o corpo à espera de pancadas. Ele, com um carinho desajeitado, tentou levantar-lhe a cabeça, o que fez com que ela se curvasse mais ainda. Sentiu remorsos por já ter batido na mulher tantas vezes. Não, ela não ficava assim longe, assim lerda por preguiça. Estava doente, muito doente. Algum encosto bravo feito por alguém. Desviou o olhar e viu a marmita em cima do fogão, enrolada num pedaço de jornal, precisava descer para o trabalho. Pousou a canequinha na beirada da janela, provocando um ligeiro ruído, com esperança de que Ponciá pudesse entender o gesto dele. Nada. Condoído, ele não sabia o que fazer. ${ }^{62}$

\footnotetext{
${ }^{61}$ Ibid. p. 29.
}

${ }^{62}$ Ibid. P. 110. 
Nas poucas vezes em que é retratado, não demonstra ter consciência de seu papel na imensa engrenagem social em que se encontra. A exploração a que é submetido no mundo do trabalho e as conseqüentes privações que experimenta em seu cotidiano, aliadas à sua ignorância, o impedem de compreender e, portanto, de reagir, aos mecanismos que o mantém preso a uma seqüência infinita de derrotas.

O personagem parece estar mantido em um estado letárgico, de suspensão. Não tem voz na narrativa, sequer recebeu um nome e foi construído sem profundidade alguma; é um personagem plano, que demonstra ser absolutamente alienado. Neste sentido, recebe da autora um tratamento benevolente que o exime de qualquer responsabilidade pelos acontecimentos que regem sua vida e aquela de sua companheira.

Já o personagem Brownfield, no romance de Alice Walker, é movido pela revolta causada por sua impotência e imobilismo, não só diante de seus fracassos e incapacidade de reagir, mas também perante o voluntarismo de sua mulher, Mem.

His mother left him each morning with a hasty hug and a sugartit, on which he sucked through wet weather and dry, across the dusty clearing or miry, until she returned [...]

At first she left him home in a basket, with his sugartit pressed against his face. He sucked on it all day until it was nothing but a tasteless rag. Then, when he could walk, she left him on the porch steps. In moments of idle sitting he shared the steps with their lean mangy dog. And as the flies buzzed around the whiskered snout of the dog they buzzed around his face. No one was there to shoo them away, or to change the sodden rag that attracted them, nd which he wore brownish and damp around his distended waist. For hours he was lost in a dull, weak stupor. His hunger made him move in a daze, his heavy eyes unnaturally bright. 
When he was four he was covered with sores. Tetter sores covered his head, eating out his hair in patches the size of quarters. Tomato sores covered his legs up to the knee - when the tomatoes in his mother's garden were ripe he ate nothing but tomatoes all day long - and pus ran from boils that burst under his armpits. His mother washed the sores in bluestone water. Suddenly, out of his days of sitting and of picking the scabs from his sores, there evolved a languid slow order of jobs he had to do. He fed the pigs, brought in wood and led the cow all over the clearing looking for fresh grass. When he was six his mother taught him how to feed and milk the cow. Then he became fond of the calm, slow patience of the cow and loved to catch her rich milk in a tin syrup pail and drink it warm and dribbling down his chin.

His father worked: planting, chopping, poisoning and picking in the cotton field, which ran for half a mile along the main road. Brownfield had worked there too now, for four years, since he was six, in the company of other child workers. His father worked with men and women in another part of the field. The cotton field too was generally silent. The children were too tired to play and were encouraged not to play because of the cotton. [... ${ }^{63}$

\footnotetext{
${ }^{63}$ WALKER,A. The third life of Grange Copeland. New York: Harcourt Books, 2003. 318 p. P. 6 - 8. "Sua mãe o deixava toda manhã com um abraço apressado e um paninho com açúcar, que ele chupava em tempo úmido ou seco, na clareira empoeirada ou lamacenta, até que ela retornasse. Ela trabalhava o dia inteiro catando minhocas por dinheiro vivo. Suas pernas estavam sempre limpas quando ela saia de casa e sempre cobertas de barro e lama das iscas quando ela voltava. As minhocas que ela "pegava" eram embaladas em latas e vendidas na cidade para cavalheiros que pescavam por hobby. Sua mãe o levou com ela para a fábrica de iscas quando ele era um bebê, mas ele atrapalhava, e as pilhas de minhocas contorcidas que eram colocadas sobre uma grande mesa para serem selecionadas o aterrorizavam. Elas pareciam ser parte da mesa até que um dia sua mãe o sentou perto delas e ele caiu e ficou enroscado nelas. Para ele as minhocas se moviam com uma agitação horripilante. Ele gritou e gritou. Mandaram sua mãe tirá-lo de lá imediatamente e nunca mais levá-lo outra vez.

No início ela o deixava em um cesto, com seu paninho encostado no rosto. Ele o chupava o dia todo até que ele se transformava em um trapo sem sabor algum. Depois, quando ele andava, ela o deixava nos degraus do alpendre. Nos momentos em que ele ficava sentado preguiçosamente, ele compartilhava os degraus com seu cachorro magro e sarnento. E quando as moscas zumbiam em volta do focinho peludo do cachorro, elas zumbiam em volta do seu rosto. Ninguém estava lá para espantá-las ou para trocar o trapo molhado que as atraía, e que ele usava encardido e úmido em sua cintura dilatada. Por horas ele ficava em um torpor débil e melancólico. Sua fome fazia com que ele se movesse atordoado, com seus olhos pesados artificialmente brilhantes.

Quando tinha quatro anos de idade ele estava coberto de feridas. Impingens cobriam sua cabeça comendo seu cabelo em espaços grandes. Feridas de tomate cobriam suas pernas até os joelhos - quando os tomates da horta da sua mãe estavam maduros ele não comia nada além de tomates o dia inteiro - e o pus escorria de furúnculos que se formavam em suas axilas. Sua mãe lavava suas feridas com calda bordalesa. Subitamente, os dias em que ficava sentado tirando as cascas de suas feridas evoluíram para uma sequiência de pequenos serviços. Ele alimentava os porcos, carregava lenha e conduzia as vacas pela clareira em busca de grama. Quando ele tinha seis anos sua mãe o ensinou a alimentar e ordenhar a vaca.
} 
Tamanho abandono prenuncia as cicatrizes emocionais que irão compor a personalidade do futuro adulto. Seu infortúnio, porém, não termina nesta fase; aos dezesseis anos é marcado por acontecimentos ainda mais trágicos: seu pai abandona a família, provocando com o seu ato o suicídio da mãe precedido pelo assassinato de seu filho caçula, o irmão bastardo de Brownfield.

Até então o narrador o trata com benevolência, mostrando suas tentativas frustradas de evitar o mesmo destino de seus pais. Ao longo da narrativa, porém, tornase impiedoso com Brownfield, responsabilizando-o em grande parte pela repetição do ciclo de destruição e morte que o acompanha.

A cada fracasso Brownfield se torna mais violento e desumano, de forma que o assassinato de Mem não chega a surpreender o leitor.

Na verdade, para Brownfield, Mem sempre personificou a força e a coragem necessárias para interromper o círculo vicioso que regia sua vida. Mem estudou, trabalhava e achava possível construir uma realidade menos injusta para si e sua família. Ela comprou o sonho americano do "self-made man" e não desistiu nunca de atingi-lo. Ingenuamente, não compreendia que fora forjada de forma a nunca alcançar seu ideal de pertencer a uma classe social diferente e inatingível.

Sua determinação, porém, realça a fraqueza de Brownfield e reforça seu sentimento de inferioridade por não conseguir alcançar o status de "pai de família" também criado pela cultura norte-americana. Desde criança, seu modelo de homem bem

Então ele se apaixonou pela paciência calma e lenta da vaca e adorava tirar seu leite em uma cuba e bebêlo morno, escorrendo pelo seu queixo.

Seu pai trabalhava: plantando, cortando, aplicando veneno e colhendo algodão no campo que se estendia por meia milha ao longo da estrada principal. Brownfield trabalhava lá agora há quatro anos, desde que tinha seis anos, na companhia dos filhos de outros trabalhadores. Seu pai trabalhava com outros homens e mulheres do outro lado do campo. O campo de algodão também era geralmente silencioso. As crianças estavam cansadas demais para brincar e eram encorajadas a não brincar devido ao algodão." (Tradução minha) 
sucedido sempre foi o homem branco, tão poderoso que conseguia intimidar seu pai. Em seus devaneios adolescentes, Brownfield sonhava com um futuro e uma família nos moldes estabelecidos pela sociedade norte-americana, nos quais ele não se encaixava.

Quando adulto, vive uma situação conflitante que o faz, ao mesmo tempo, amar e odiar seus modelos de masculinidade e poder até a chegada do momento em que passa a culpar o outro pelos seus fracassos. E é exatamente esta postura que o narrador apresenta como inaceitável: para sobreviver e mudar uma herança de abandono e destruição os homens negros devem aprender a refletir e a assumir responsabilidade por seus atos.

\begin{abstract}
"Walker creates a multiplicity of permanently maimed and damaged souls within the family structure who feel no pressure for responsible living or assume exemption from the demands of responsibility. There may be occasions of optimism and hope [...] But more pervasive in Walker's fiction is despair: [...] people who allow themselves to become animals, such as Brownfield in The third life of Grange Copeland, who, accepting a "nothingness" in himself, shoots his wife in the face while his children watch [...]" ${ }^{64}$
\end{abstract}

A tese apresentada, no entanto, é controversa. Brownfield e sua família, bem como os demais afro-descendentes norte-americanos de sua época, estão inseridos em uma sociedade fortemente marcada por relações étnico-raciais desiguais que tem o homem branco, descendente de europeus, como detentor do poder. Desde sempre, são

${ }^{64}$ DAVIS, T. M. Walker's celebration of self in southern generations. In: BLOOM, H. (ed.) Alice Walker. New York: Chelsea House Publisher, 1989. 245 p. P. 27 - 28. "Walker cria uma multiplicidade de criaturas permanentemente feridas e arruinadas no interior da estrutura familiar, que não sentem pressão alguma para uma vida responsável ou isentam-se das demandas da responsabilidade. Pode haver momentos de otimismo e esperança [...] Porém, mais penetrante na ficção de Walker é o desespero: [...] pessoas que se permitem transformar em animais, tal como Brownfield em A terceira vida de Grange Copeland, que, aceitando uma "insignificância" em sí mesmo, atira no rosto de sua esposa enquanto suas filhas observam." (Tradução minha) 
os poderosos e vitoriosos que são transformados em ídolos a serem imitados; o problema é que, no caso, são modelos de força e impiedade para com aqueles que se encontram em situação inferior na escala social.

Aliado a esta herança sócio-cultural há o fato de o país ser também o maior representante do capitalismo no mundo moderno e, portanto, ter as estruturas de pensamento de sua sociedade por ele geradas.

Dessa maneira, a luta da família Copeland em afirmar-se e integrar-se a uma sociedade que exacerba a divisão de classes e, através do trabalho assalariado, desvaloriza cada vez mais o indivíduo, revela-se fadada ao fracasso. Além de fazerem parte da grande massa de trabalhadores rurais do sul do país, desqualificados para qualquer tipo de trabalho que possa resultar em ascensão financeira e, consequentemente, social, eles são negros, "the underclass of the underclass." (Willis, 1989, p. 94).

\subsection{GRANGE COPELAND E VÔ VICÊNCIO}

Ambos os romances têm como pano de fundo o sistema capitalista condicionando as famílias representadas e definindo as relações humanas. Tanto The third life of Grange Copeland quanto Ponciá Vicêncio apresentam famílias de lavradores pobres convivendo com a miséria e a desagregação. Nos dois casos o explorador econômico se faz presente através das figuras dos proprietários das terras: nos Estados Unidos, Mr. Shipley e Mr. J. L., no Brasil, a Família Vicêncio. Ambos 
apresentam personagens deslocando-se do mundo rural para a sociedade industrial, sofrendo o impacto desta mudança e reagindo, cada um a seu modo, aos novos desafios que tal situação impõe, buscando formas de adaptação e de superação das dificuldades encontradas. Permeando ambas as obras, faz-se presente a figura do avô, sempre atuando de maneira direta ou indireta na vida de todos os familiares.

No caso do romance afro-americano, o avô é o personagem principal da história, sendo, portanto, acompanhado e descrito ao longo da narrativa com especial atenção. Todos os outros personagens gravitam ao seu redor e são, de uma forma ou outra, por ele influenciados. É dele também a responsabilidade pela grande maioria dos acontecimentos envolvendo sua família.

No romance afro-brasileiro o avô está presente simbolicamente, através do boneco de barro que o representa, mas sua história é revelada pela protagonista (através de flashbacks) e é através dela que o leitor pode mensurar o peso da vida e atitudes de Vô Vicêncio no desenrolar dos fatos envolvendo sua mulher, filho e netos, antes e após a sua loucura e posterior morte.

Grange Copeland precisa viver duas vidas - correspondentes à juventude e à maturidade - regidas pela submissão, pela revolta e pela violência, para finalmente alcançar a serenidade, advinda da construção da auto-estima e da independência financeira. $\mathrm{O}$ alcance de tal serenidade dá início à terceira vida, correspondente à velhice, quando poderá criar e educar a neta, Ruth, em novos moldes. Seu objetivo maior é formar uma mulher forte, segura e independente, tanto psicológica quanto financeiramente - tudo o que ele não proporcionou ao filho, Brownfield - para que ela tenha condições não só de sobreviver, mas principalmente, de viver plenamente, construindo um futuro onde a pobreza, a humilhação e a exploração não estejam presentes. 
Em sua trajetória rumo à terceira vida, Grange praticamente não faz uso da violência física, mas a violência psicológica sobre os seus é exercida o tempo todo, com consequiências terríveis. Em seu casamento, por exemplo, de certo modo ele compreende e aceita as traições que sua mulher passa a cometer após o esfacelamento de sua relação, chegando até a aceitar um filho que não é seu, porém não a perdoa quando ela se envolve com um homem branco. Percebendo que está prestes a matá-la, ele prefere sair de casa, para não mais voltar, a concretizar o assassinato.

When Brownfield woke in the night his mother was gone. From his bed in the kitchen he could see his father sitting on the bed, cradling something in his arms. It was long and dark, like a steel rod, and glinted in the light from the kerosene lamp. Grange's face was impassive, its lines brooding. Placing the rifle on the bed he picked up his dusty black-green hat. He stood looking at the floor, his shoulders slumped, motionless. He looked very old. Ploddingly he moved about the room. He waited indecisively for his wife to return. He gazed at the baby asleep in its makeshift crib, a crate that had once been filled with oranges. He shrugged. Then he lifted his eyes toward where Brownfield's bed was, at one side of the kitchen, between the table and the stove. Slowly he walked into the kitchen, which was chilly and smelled of old biscuits, and which changed to a new rhythm of night with his entrance into it. The air was gently agitated by his movements. The sounds of the floor shifted with each step he took.

Brownfield pretended to be asleep, though his heart was pounding so loudly he was sure his father would hear it. He saw Grange bend over him to inspect his head and face. He saw him reach down to touch him. He saw his hand stop, just before it reached his cheek. Brownfield was crying silently and wanted his father to touch the tears. He moved towards his father's hand, as if moving unconsciously in his sleep. He saw his father's hand draw back, without touching him. He saw him turn sharply and leave the room. He heard him leave the house. And he knew, even before he realized 
his father would never be back, that he hated him for everything and always would. And he most hated him because even in private and in the dark and with Brownfield presumably asleep, Grange could not bear to touch his son with his hand.

"Well, He's gone," his mother said without anger at the end of the third week. But the following week she and her poisoned baby went out in the dark of the clearing and in the morning Brownfield found them there. She was curled up in a lonely sort of way, away from her child, as if she had spent the last moments on her knees. ${ }^{65}$

Sua opção pelo abandono da família como uma forma de não praticar um ato violento não é bem sucedida. Como o recorte acima ilustra, sua partida desencadeia acontecimentos gravíssimos: Margaret pratica violência contra si mesma e o próprio filho e Brownfield fica com uma ferida emocional profunda que irá acompanhá-lo por toda a vida e será parte importante na formação de sua personalidade. $\mathrm{O}$ adulto Brownfield será um homem carente, inseguro e extremamente cruel com a mulher e

\footnotetext{
${ }^{65}$ WALKER,A. The third life of Grange Copeland. New York: Harcourt Books, 2003. 318 p. P..25 26.

"Quando Brownfield acordou no meio da noite, sua mãe havia saído. Da sua cama na cozinha ele podia ver seu pai sentado na cama, embalando alguma coisa em seus braços. Era longo e escuro, como uma vara de aço, e brilhava sob a luz de uma lamparina, O rosto de Grange estava impassível. Colocando o rifle sobre a cama ele pegou seu chapéu preto empoeirado. Ele ficou olhando para o chão, seus ombros caídos, imóveis. Parecia muito velho. Pensativamente ele se movia pelo quarto. Ele esperava hesitantemente pela volta da sua mulher. Observou o bebê dormindo em seu berço improvisado, um berço que outrora havia estado repleto de laranjas. Ele deu de ombros. Depois ele levantou seus olhos em direção à cama de Brownfield, em um lado da cozinha, entre a mesa e o fogão. Vagarosamente caminhou para a cozinha, que estava fria e cheirando a biscoitos velhos, e que mudou para um novo ritmo de noite com a sua entrada. $\mathrm{O}$ ar foi mansamente agitado pelos seus movimentos. Os ruídos do assoalho se alteravam com cada passo que ele dava.

Brownfield fingia estar dormindo, embora seu coração estivesse batendo tão forte que ele tinha certeza que seu pai poderia ouvi-lo. Ele viu Grange debruçar-se sobre ele para observar sua cabeça e seu rosto. Ele o viu abaixar-se para tocá-lo. Ele viu a sua mão parar antes de tocar sua face. Brownfield estava chorando silenciosamente e queria que seu pai sentisse suas lágrimas. Ele se moveu em direção à mão de seu pai, como se estivesse se mexendo inconscientemente durante o sono. Ele viu a mão de seu pai recuar, sem tocá-lo. Ele o viu virar-se bruscamente e sair do quarto. Ele o ouviu deixar a casa. E ele sabia, mesmo antes de compreender que seu pai jamais voltaria, que ele o odiava por tudo e sempre odiaria. E ele o odiava mais ainda porque mesmo privadamente e no escuro e com Brownfield supostamente dormindo, Grange não suportava tocar seu filho.

"Bom, ele foi embora," sua mãe disse, sem raiva, ao final da terceira semana. Porém, na semana seguinte ela e seu bebê envenenado foram para a escuridão da clareira e de manhã Brownfield os encontrou lá. Ela estava encurvada de um jeito solitário, longe de seu filho, como se tivesse passado os últimos momentos ajoelhada." (Tradução minha)
} 
filhas, assassinando a primeira e causando danos emocionais terríveis nas filhas, principalmente nas mais velhas, Daphne e Ornette.

Daphne was more forgiving than Ornette. Her temper became murderous only when Brownfield abused Mem. When Brownfield beat Daphne she tried to endure it by keeping her mind a perfect though burning blank. She tried so hard to retain some love for him, perhaps because of her memories of an earlier time, that she became very nervous. She jumped at the slightest noise or movement. Because she was so jumpy Brownfield teased her and called her names. He told her she was stupid and crazy. He swore at her, called her Daffy instead of Daphne, and pinched her sides until they bruised. Through it all she bravely stood, seeking to hide her trembling as best she could. [...]

Ornette was jolly most of the time. A loud, boisterous girl, sassy and full of darting rebellion. She was fat and glossy. Her skin had a luscious orange smoothness and felt like a waxed fruit. Of the three children Brownfield appeared to like her least. He thought she would grow up to be a plump, easy-going tramp and was telling her so constantly by the time she was eight. Ornette learned to toss her head at him. When she was seven she refused to go to church or to say her bedtime prayers. She had a flexible sexual vocabulary at eight and a decided interest in pussies and bowwows at nine. Her opinion of the house was that it was a barn and that only the stupidest cows lived in worse $[\ldots]$ Ornette was bold with her mother, thought her a hag and of little account. She thought Mem had married beneath her and should have married instead a teacher or a mason or anybody with land of his own and a fine house. She did not respect Mem. Occasionally she stole pennies from Mem's purse."

\footnotetext{
${ }^{66}$ Ibid. p. 147 - 148. "Daphne era mais generosa que Ornette. Seu temperamento se tornava cruel quando Brownfield maltratava Mem. Quando Brownfield batia em Daphne ela tentava suportar conservando a sua mente um perfeito, embora abrasador, vazio. Ele tentou tanto conservar um pouco de amor por ele, talvez devido às suas lembranças do passado, que ela se tornou muito nervosa. Ela pulava ao menor barulho ou movimento. Porque ela era tão assustada Brownfield a provocava e xingava. Ele lhe dizia que ela era imbecil e louca. Ele a chingava e a chamava de Daffy ao invés de Daphne, e também a beliscava
} 
"Daphne felt strongly tensions in the house to which Ruth and Ornette were oblivious. She was always having to look out for them, because Brownfield, even when sober, would beat and kick them." ${ }^{, 67}$

"Daphne, always brooding and nervous so that if you walked into a room behind her and said "Hey!" she was likely to go into convulsions, was holding her stomach. She did this whenever she was upset or confused. She had bad sickness once a month and would cry and cry, and one time, when she was holding her stomach and crying, with sweat popping out like grease bubbles on her face, Brownfield had kicked her right where her hands were. He was trying to sleep, and couldn't because of the noise, he said.

Mem had taken Daphne to the clinic, but the nurse said she didn't see anything wrong with her, except that she was nervous. Mem had said that she knew the child was nervous and wanted the nurse to tell her what to do about it, but the nurse was busy talking to another nurse about changing her hair color, and both ignored Mem, who was standing there exasperated, holding a quivering Daphne by the hand. 68

No decorrer da narrativa, sem muita surpresa, o leitor é informado que Daphne enlouqueceu (... Daphne's in a crazy house up North) e Ornette tornou-se uma prostituta (Ornette's a - a lady of pleasure"). (Walker, 2003, p. 276).

até ela ficar roxa. A tudo isso ela resistia bravamente, tentando esconder seu tremor da melhor maneira que podia." (Tradução minha)

${ }^{67}$ Ibid. p. 155. "Daphne sentia vigorosamente as tensões da causa, as quais não eram percebidas por Ruth e Ornette. Ela estava sempre procurando por elas porque Brownfield, mesmo quando sóbrio, as espancava e chutava." (Tradução minha)

${ }^{68}$ Ibid. P. 157 - 158. "Daphne, sempre preocupada e nervosa de modo que se você entrasse em um cômodo atrás dela e dissesse "Hey!"ela provavelmente teria convulsões, estava segurando seu estômago. Ela fazia isso sempre que estava perturbada ou confusa. Ela passava mal uma vez por mês e chorava e chorava, e uma vez, quando ela estava segurando seu estômago e chorando, com o suor deslizando como gotas de gordura pelo seu rosto, Brownfield a chutou exatamente onde suas mãos estavam colocadas. Ele estava tentando dormir, e não conseguia por causa do barulho, ele disse.

Mem havia levado Daphne ao médico, mas a enfermeira disse que não via nada errado com ela, exceto que ela estava nervosa. Mem disse que ela sabia que a criança estava nervosa e queria que a enfermeira lhe dissesse o que fazer, mas a enfermeira estava ocupada conversando com outra enfermeira sobre mudar a cor do seu cabelo, e ambas ignoraram Mem, que estava parada lá, exasperada, segurando uma trêmula Daphne pela mão.” (Tradução minha) 
Em sua segunda vida em Nova York, Grange aprende a roubar e a trapacear. Por vezes também acaba por agredir pessoas fisicamente e, finalmente, em sua terceira vida, Grange mata o próprio filho, Brownfield, convencido de que esta é a única forma de quebrar o círculo vicioso no qual sua família está inserida e proporcionar a Ruth a oportunidade de construir um futuro diferente. Seu relacionamento com Josie, a dona de bordel que foi sua amante, depois amante de Brownfield e por fim sua mulher, também foi conturbado. Josie foi apenas um instrumento útil para que ele alcançasse seu objetivo de tornar-se independente financeiramente.

O personagem deixou um rastro de violência física e psicológica nos caminhos que trilhou ao longo de sua vida, porém, diferentemente de Brownfield, a ele é oferecida a oportunidade de redenção. A autora é benevolente com Grange e o presenteia com a neta Ruth, que se torna objeto de seu amor e mola propulsora de seu processo de regeneração.

Um fator determinante para sua transformação é a sua ida para Nova Iorque e o conseqüente aprendizado proporcionado pela experiência adquirida com o deslocamento da sociedade rural para a sociedade industrial.

Return is the developmental imperative in all Walker's novels, where the journey over geographic space is a metaphor for personal growth and, in a larger sense, historical transformation. In her first novel, The third life of Grange Copeland, Walker's conception of geographic space embodies a dialectical understanding of history. When Grange Copeland abandons wife and child to seek his self and fortune in New York City, he leaves behind a rural community historically representative of the plantation system for the North and the industrial mode. The third moment of the dialectic is marked by Grange's return to the south, not as a penniless sharecropper, but with money in his pocket to buy his own land. The farm Grange brings into being 
suggests Walker's vision of a very different basis for black community, one which has experienced and transcended two forms of enslavement: first to the plantation, then to wage labor. In Walker's vision of the future, property ownership will not be for the purpose of accumulation as it is under capitalism, but will provide for the satisfaction of basic human material and spiritual needs. ${ }^{69}$

O norte do país, com o comércio e a indústria em franco desenvolvimento, apresentava uma sociedade que convivia com o capitalismo em estágio mais avançado, fato este que iniciou Grange em duas regras importantes da sociedade capitalista industrial: a primeira é o acúmulo de dinheiro (obtido tanto através de formas lícitas quanto ilícitas) como pré-requisito para alcançar a independência e o respeito como indivíduo, e a segunda, consequiência direta da primeira, é a invisibilidade social imposta àqueles que não conseguem alcançar tal feito.

Fazendo uso do aprendizado adquirido, admitindo os erros cometidos e assumindo responsabilidade por sua vida e escolhas, Grange consegue levar a cabo a tarefa que se impôs, de criar e orientar Ruth para enfrentar os desafios que, com certeza, farão parte de seu futuro como jovem e adulta.

No romance afro-brasileiro, Vô Vicêncio é apresentado de maneira contraditória, na medida em que sua lucidez está estreitamente vinculada à sua loucura. Vivenciando

\footnotetext{
${ }^{69}$ WILLIS, Susan. Walker's women. In: BLOOM. H. (ed.) Alice Walker. New York: Chelsea House Publishers, 1989. 245 p. P. 81. "O retorno é um imperativo desenvolvimental em todos os romances de Walker, onde a jornada pelo espaço geográfico é uma metáfora para o crescimento pessoal e, em um sentido amplo, para a transformação histórica. Em seu primeiro romance, A terceira vida de Grange Copeland, a concepção de Walker de espaço geográfico personifica um entendimento dialético da história. Quando Grange abandona mulher e filho para procurar seu eu e fortuna na cidade de Nova Iorque, ele deixa para trás uma comunidade rural historicamente representativa do sistema de "plantantion" para ir para o norte e o modo industrial. O terceiro momento da dialética é marcado pela volta de Grange para o sul, não como um meeiro sem um tostão, mas com dinheiro em seu bolso para comprar suas terras. A fazenda que Grange formou sugere a visão de Walker de uma base muito diferente para a comunidade negra, que experimentou e ultrapassou duas formas de escravidão: primeiro na lavoura, depois no trabalho remunerado. Na visão de futuro de Walker, a posse de uma propriedade não tem o propósito de acumulação como tem sob o capitalismo, mas proporcionará a satisfação das necessidades materiais e espirituais básicas do ser humano." (Tradução minha)
} 
os mesmos problemas que o personagem afro-americano, ele não consegue evitar a violência, que pratica contra a mulher e ele próprio. A consciência de sua impotência, na condição de escravo ainda, levou-o à única forma de reação que poderia vislumbrar:

No tempo do fato acontecido, como sempre os homens e muitas mulheres trabalhavam na terra. $\mathrm{O}$ canavial crescia dando prosperidade ao dono. Os engenhos de açúcar enriqueciam e fortaleciam o senhor. Sangue e garapa podiam ser um líquido só. Vô Vicêncio com a mulher e os filhos, viviam anos e anos nessa lida. Três ou quatro dos seus, nascidos do "ventre livre", entretanto, como muitos outros, tinham sido vendidos. Numa noite, o desespero venceu. Vô Vicêncio matou a mulher e tentou acabar com a própria vida. Armado com a mesma foice que lançara contra a mulher, começou a se autoflagelar decepando a mão. Acudido é impedido de continuar o intento. Estava louco, chorando e rindo. Não morreu o Vô Vicêncio, a vida continuou com ele, independentemente do seu querer. Quiseram vendê-lo. Mas quem compraria um escravo louco e com o braço cotó? Tornou-se um estorvo para os senhores. Alimentava-se das sobras. Catava os restos dos cães, quando não era assistido por nenhum dos seus. Viveu ainda muitos e muitos anos. Assistiu, chorando e rindo, aos sofrimentos, aos tormentos de todos. E só quando acabou de rir todos os seus loucos risos e de chorar todos os seus insanos prantos, foi que Vô Vicêncio se quedou calmo. ${ }^{70}$

Seu ato leva o filho, que testemunhou o acontecimento e que anos depois se tornou pai de Ponciá, a odiá-lo e apenas tolerá-lo, mas não desencadeia um comportamento violento dele com relação à família, como ocorreu com Brownfield.

A presença dele na vida da neta, porém, é sentida com intensidade, pois é Ponciá que se torna depositária de sua herança: a loucura. A mensagem é clara: muitos anos se

\footnotetext{
${ }^{70}$ EVARISTO, Conceição. Ponciá Vicêncio. Belo Horizonte: Mazza, 2005. 132 p. p. 50-51.
} 
passaram desde o homicídio cometido por Vô Vicêncio e desde o advento da Abolição da Escravidão, entretanto a situação de Ponciá Vicêncio e, simbolicamente, dos demais afro-descendentes brasileiros, continua praticamente inalterada, com raras exceções.

Tal situação pode ser traduzida e explicada por Susan Willis, ao afirmar que:

Em vez de mudanças o capitalismo é assinalado por eventos, tais como lançamentos de foguetes à Lua e descobertas científicas, ou pelo horror de acontecimentos como o holocausto nuclear. É obvio que há lutas por mudanças: direitos civis, o movimento feminista, desarmamento nuclear e antibélico. Mas numa história dominada pelo progresso, essas lutas não levam senão a reformas.

Tudo se transforma, mas nada muda, eis o lema adequado para este capitalismo de fim de século. ${ }^{71}$

Em uma sociedade situada na periferia do capitalismo, como é o caso do Brasil, onde a desigualdade social é intensa, geradora de extrema pobreza e conseqüente exclusão social, tal lema aplica-se com perfeição, como bem explica Roberto Schwarz.

[...] o desenvolvimento dos países subdesenvolvidos não leva ao desenvolvimento senão em aparência, pois assim como, chegado o momento, estes repõem o seu travejamento social "arcaico", o capitalismo visto no todo e em plena ação modernizante também repõe a situação subdesenvolvida, que nesse sentido faz parte do travejamento arcaico da própria sociedade contemporânea, de cujo desenvolvimento seria o caso de duvidar. ${ }^{72}$

\footnotetext{
${ }^{71}$ WILLIS, Susan. Cotidiano: para começo de conversa. Rio de Janeiro: Graal, 1997. 230 p. p. 49-50.

72 SCHWARZ. Roberto. Um seminário de Marx. In: Seqüências Brasileiras. São Paulo: Cia. das Letras, 1999. 249 p. p. 101.
} 
Reflexos desta constatação, "com a parte de realismo - se não de verdade - que acompanha as desilusões" (Schwarz, 1992, p. 64), são encontrados na forma benevolente com que Conceição Evaristo apresenta a figura do avô. Ele não é criticado por seu ato; ao contrário, justificativas para tal comportamento são enumeradas, e sua presença, representada pelo boneco de barro, acompanha Ponciá Vicêncio ao longo de toda a sua trajetória rumo ao fracasso e à loucura que, aliás, se caracteriza como aquela do avô: choros e risos. Em nenhum momento é sequer cogitada outra possibilidade que pudesse ter evitado a atitude destemperada do avô. Vô Vicêncio é amado e respeitado por seus descendentes, que o vêm apenas como uma vítima impotente do sistema.

Assim, verifica-se que em ambos os romances, caracterizados pela apresentação de trajetórias de vida da população de afro-descendentes em busca de integração com o sistema dominante, há uma preocupação em construir um passado para a comunidade negra.

Tal preocupação origina-se na necessidade de construir um ponto de referência sobre o qual as futuras gerações possam se assentar, uma vez que o conhecimento dos ancestrais, e suas respectivas histórias, configura-se como fator determinante para a construção de indivíduos seguros e equilibrados.

Em todas as sociedades, sejam elas muito ou pouco desenvolvidas, os indivíduos se vêm como frutos de uma linhagem - nobre ou não - ou como um elo na cadeia de gerações, fato este que permite uma volta ao passado sempre que a necessidade de buscar referências pessoais se faz presente.

Este exercício revela-se altamente complexo, se não impossível, para os descendentes de escravos, uma vez que o sistema escravocrata provocou uma experiência de desmembramento aos africanos que foram transpostos para os países que faziam uso daquele sistema. Como é de conhecimento geral, os traficantes de escravos, 
bem como os seus compradores, tinham um cuidado especial em separar as famílias bem como agrupar membros dos diferentes grupos étnicos oriundos da África com a finalidade de evitar qualquer forma de reação que pudesse advir.

Membros de sociedades com diferentes formas de organização e falantes de diferentes dialetos eram agrupados - de modo que a comunicação entre eles fosse impossível - e a eles era imposta a língua falada no país que os recebia. Partindo do princípio de que a língua é a melhor forma de dominação e manipulação de um povo, verifica-se que este processo, aliado à imposição da cultura de origem européia, levou ao apagamento da memória familiar e cultural.

Como agravante, eram mantidos em uma posição de inferioridade em uma sociedade onde a cultura e os valores do homem branco eram os parâmetros pelos quais tudo o mais era avaliado. Considerados um povo bárbaro, tiveram sua cultura discriminada e, consequentemente desvalorizada, o que acarretou a supressão de hábitos, comportamentos e crenças característicos da cultura africana. Em seu lugar, foi promovida a aceitação da cultura dominante, que não os reconhecia e na qual não conseguiam se enquadrar.

Assim, ao escolher Grange Copeland e suas três vidas como eixo central do romance The third life of Grange Copeland, e Ponciá, sempre vinculada à figura do avô (em uma espécie de simbiose), como figura central do romance Ponciá Vicêncio, tanto Alice Walker quanto Conceição Evaristo buscam reconstruir as origens da comunidade negra. Ao proporcionar a esta camada da população um passado e, consequentemente uma história, visam promover a valorização da cultura africana - rica e secular - bem como a dignidade e o orgulho da população negra. Dentro deste raciocínio, os afrodescendentes também teriam uma ancestralidade à qual poderiam recorrer no processo 
de construção da auto-estima, que por sua vez daria sustentação à formação de sujeitos fortes e independentes.

\subsection{LUANDI JOSÉ VICÊNCIO}

Assim como Ponciá, Luandi partiu para a "cidade grande" em busca de trabalho e ascensão financeira e social. Sua chegada também não foi muito diferente daquela da irmã.

[...] Chegou num dia de chuva e frio. Trazia muita fome também.

A chuva incomodava Luandi. A roupa colada em seu corpo e os sapatos molhados causavam-lhe desconforto. Estava calçado pela primeira vez. Na roça sempre andara de pés no chão. As luzes dos postes querendo tapear a escuridão da noite aborreciam profundamente o moço. "Para que eu vim pra cidade?", perguntou-se entre os dentes, resmungando, como era hábito de seu pai. "Para que eu vim pra cidade?", se perguntou novamente. Achar minha irmã, juntar dinheiro e ficar rico. Diziam que na cidade as pessoas trabalham muito, mas ficam ricas. E de trabalho Luandi não tinha medo [...]

[...] Luandi não tinha onde passar a noite e depois de caminhar um pouco, resolveu voltar para a estação. Poderia assentar ou até deitar em uns dos bancos e esperar o dia seguinte. Foi acordado, entretanto, no meio do sono por um soldado: "O que você está fazendo aqui? Mostre os documentos. O que você faz? Você está armado?" Luandi respondeu-lhe que não tinha trabalho ainda. Não tinha documentos. Tinha acabado de chegar lá da roça. Foi, então, revistado: no bolso um canivete. Estava armado! "Por isso é melhor você me seguir até a delegacia." Soldado Nestor pegou Luandi pelo braço e foi levando. 
Fazia força, apertava-lhe o braço. Um funcionário que varria a estação ficou olhando. Era negro também [...] ${ }^{73}$

Seu ingresso na sociedade industrial urbana em nada difere daquele de toda gama de migrantes pobres e marginalizados brasileiros: chegam às metrópoles carregados de expectativas, que são frustradas logo no primeiro contato com a realidade local. Assim, Luandi é primeiramente considerado um "vagabundo", depois um "provável criminoso" e, finalmente, é levado à delegacia onde, uma vez confirmada sua estória, lhe é oferecido o emprego de faxineiro. É a ideologia do favor entrando em ação.

Luandi dormia na delegacia. Tinha feito dali a sua casa. Um dia veio o desejo de voltar ao povoado. Pediu ao Soldado Nestor. Soldado Nestor pediu ao delegado. Tudo certo. $\underline{\mathrm{O} \text { moço merecia. Trabalhava tanto. }}$ Era tão humilde e zeloso. Podia ir descansar um pouco... (grifo meu) ${ }^{74}$

Subempregado, morando "de favor" na delegacia, tendo como ídolo um homem negro que é soldado, freqüentando a zona de prostituição, apaixonando-se por uma prostituta - Belisa, posteriormente assassinada por seu gigolô - que também tem uma história pessoal de exploração e marginalização, Luandi segue acalentando seu sonho de tornar-se soldado, ter poder para "prender e bater", comprar uma casa e encontrar a irmã e a mãe para voltarem a morar juntos novamente.

Não consegue enxergar a realidade e não tem consciência de que foi forjado de forma a não atingir seus objetivos. Sua situação na delegacia de polícia é um pouco

\footnotetext{
${ }^{73}$ EVARISTO, Conceição. Ponciá Vicêncio. Belo Horizonte: Mazza, 2005. 132 p. p. 69-70.

${ }^{74}$ Ibid. p. 78.
} 
melhor do que aquela que tinha no campo, porém insuficiente para que ele ascenda financeira e socialmente. Sob o manto do favor, imagina ter mais dignidade e perspectivas.

Sua história ilustra de maneira singular a continuidade da ideologia do favor na cultura brasileira. Através de sua trajetória verifica-se com toda clareza que, apesar de estar inserido em outro momento histórico, Luandi continua sendo refém de um macabro mecanismo social que insiste em dominar as relações de classe no Brasil.

No momento da prestação e da contraprestação - particularmente no instante-chave do reconhecimento recíproco - a nenhuma das partes interessa denunciar a outra, tendo embora a todo instante os elementos necessários para fazê-lo. Esta cumplicidade sempre renovada tem continuidades sociais mais profundas, que lhe dão peso de classe: no contexto brasileiro, o favor assegurava às duas partes, em especial à mais fraca, de que nenhuma é escrava. Mesmo o mais miserável dos favorecidos via reconhecida nele, no favor, a sua livre pessoa, o que transformava prestação e contraprestação, por modestas que fossem, numa cerimônia de superioridade social, valiosa em si mesma. Lastreado pelo infinito de dureza e degradação que esconjurava - ou seja a escravidão, de que as duas partes beneficiam e timbram em se diferenciar - este reconhecimento é de uma conveniência sem fundo, multiplicada, ainda, pela adoção do vocabulário burguês da igualdade, do mérito, do trabalho, da razão. ${ }^{75}$

Embora descrevendo a sociedade escravista do século XIX e as relações sociais em nosso país desenvolvidas a partir da junção daquela realidade nacional com a importação das idéias liberais oriundas da Europa, as considerações de Roberto Schwarz revelam-se espantosamente atuais. Com pequenas adaptações, as idéias continuam fora

\footnotetext{
${ }^{75}$ SCHWARZ. R. As idéias fora do lugar. In: Ao vencedor as batatas. São Paulo: Livraria Duas
} Cidades, 1992. 169 p. p. 18 - 19. 
do lugar e são em grande parte responsáveis pelo abismo que separa as classes sociais brasileiras. Mais de um século após o Período Colonial e Escravista, o Brasil continua abrigando uma imensa população de marginalizados que sobrevivem à custa do favor dos governantes, do favor das Organizações Não Governamentais (ONGs) e do favor de membros da sociedade civil que subempregam indivíduos para a realização de trabalho não especializado ou ainda fazem doações junto a instituições de caridade. Assim, com a "consciência tranqüila" por estarem ajudando os "menos favorecidos" seguem impávidos em sua conivência com o sistema. A essa população de marginalizados, composta por afro-descendentes e demais frutos da miscigenação racial, resta o consolo de fazer parte de "uma sociedade onde a democracia racial e social se faz presente", impregnados que estão pela ideologia nacional - vista aqui como "engano involuntário e bem fundado nas aparências.” (Schwarz, 1992, p. 17)

Inserido nesse contexto, após muitos anos Luandi finalmente aprende a ler e a escrever, consegue se tornar soldado e também reencontra a mãe e a irmã. Porém, o reencontro com a família, ou com o que restou dela - a mãe envelhecida e fragilizada e a irmã dominada pela loucura - não fez de Luandi um homem realizado. Ao contrário, ele finalmente percebe que é apenas uma pequena peça na complexa engrenagem social brasileira.

Luandi José Vicêncio olhava o rosto conturbado da irmã, que caminhava em círculos. [...] A irmã tinha os traços e os modos de Vô Vicêncio. Não estranhou a semelhança que se fazia cada vez maior. Bom que ela se fizesse reveladora, se fizesse herdeira de uma história tão sofrida, porque enquanto o sofrimento estivesse vivo na memória de todos, quem sabe não procurariam, nem que fosse pela força do desejo, a criação de um outro destino. E ele que queria tanto ser soldado, mandar, bater, prender, de repente descobria de que nada valia a realização de seus desejos, se fossem aqueles os sentidos de 
sua ação, de sua vida. Soldado Nestor era tão fraco e tão sem mando como ele. Apenas cumpria ordens, mesmo quando mandava, mesmo quando prendia. Foi preciso que a herança de Vô Vicêncio se realizasse, se cumprisse na irmã para que ele entendesse tudo. Só agora atinava também com o riso e as palavras de Nêngua Kainda. Ele, que levara tanto tempo desejando a condição de ser soldado, em poucos minutos escolhia desfazer-se dela. [...] Assim como antes acreditava que ser soldado era a única e melhor maneira de ser, tinha agora uma nova descoberta. Compreendera que sua vida, um grão de areia lá no fundo do rio, só tomaria corpo, só engrandeceria, se se tornasse matéria argamassa de outras vidas. Descobria também que não bastava saber ler e assinar o nome. Da leitura era preciso autorizar o texto da própria vida, assim como era preciso ajudar a construir a história dos seus. E que era preciso continuar decifrando nos vestígios do tempo os sentidos de tudo que ficara para trás. E perceber que, por baixo da assinatura do próprio punho, outras letras e marcas havia [...] 76

Sua conscientização não o leva, entretanto, a buscar e questionar a causa de seus problemas. Assim como o companheiro de Ponciá, Luandi parece estar anestesiado e simplesmente não consegue entender as forças sociais e políticas que o prendem a um estado permanente de alienação. Ao compreender a realidade e decidir voltar para o campo com sua família, ele aceita, sem contestação, a sua condição de marginalizado, o que vem comprovar a força bruta do sistema e das estruturas de pensamento equivocadas que sempre reinaram e ainda reinam na sociedade brasileira.

\subsection{A FAMÍLIA}

\footnotetext{
${ }^{76}$ EVARISTO, Conceição. Ponciá Vicêncio. Belo Horizonte: Mazza, 2005. 132 p. p. 130 - 131.
} 
Outro ponto de convergência entre Alice Walker e Conceição Evaristo é a importância que ambas conferem à constituição da família nuclear como pré-requisito para a formação de indivíduos fortes e equilibrados. Mantendo-se afastadas das críticas materialistas à família nuclear burguesa, ambas insistem na necessidade de relações de "amor, carinho, amizade e lealdade" entre os membros da família como forma de construir um mundo privado - o lar. Tradicionalmente associado à classe média branca, ele é apresentado pelas escritoras como uma espécie de "porto seguro" que irá nutrir os personagens com a força e a coragem necessárias para atingir seus objetivos de enfrentamento e transformação da realidade na qual estão inseridos. Ambas apontam categoricamente a família e o lar como espaço vital de resistência ao racismo.

Assim, Ruth - a neta de Grange Copeland - só consegue sobreviver à seqüência de tragédias que acompanhavam sua família e ter uma infância e adolescência relativamente normais após ter sido acolhida e criada na atmosfera de um "lar", constituído por Grange, Josie e ela.

O mesmo efeito benéfico e curativo do "lar e da família" é apresentado em Ponciá Vicêncio. É o reencontro de Ponciá com a mãe e o irmão que parece amenizar as dores de todos, embora não possa mais ajudá-la a conviver com a realidade, e foi a percepção de que havia perdido todos os entes queridos - pai, mãe, irmão, fillhos e o marido - que contribuiu grandemente para levá-la à loucura. Luandi também só volta a se equilibrar emocionalmente ao reencontrar a mãe e a irmã, momento este que simboliza o fim da desintegração familiar ocorrida com a mudança para o núcleo urbano e o início de um novo período de agregação de forças para o enfrentamento da realidade.

A história de Ponciá Vicêncio formaliza e dá realidade literária a uma série de problemas sociais há muito conhecidos e ignorados pela sociedade brasileira: a 
exploração da mão-de-obra dos trabalhadores, tanto da zona rural quanto da urbana; a migração para as grandes cidades, que não estão preparadas para orientar e acomodar os recém-chegados; a omissão das instituições públicas, bem como da Igreja, secularmente identificada como grande auxiliadora dos desvalidos; os sonhos enganadores de ascensão social, construídos pelo mesmo discurso que os destrói; a violência contra a mulher; e os reflexos, ainda presentes, da falta de políticas de assistência e orientação que caracterizou o período imediato à Abolição da Escravidão. Enfim, Conceição Evaristo nos apresenta um núcleo de perdedores que materializam a força bruta de uma sociedade voltada para o lucro e o consumo, onde não há espaço para a compreensão e aceitação da diferença.

A única saída que se apresenta como possível é a arte. O trabalho de modelagem do barro, realizado por Ponciá e pela mãe, e que se configura como um elo fortalecedor da união de ambas, além de suprir as necessidades da família, é a habilidade não esquecida por Ponciá depois de seu mergulho sem volta no vazio da existência.

Ponciá Vicêncio [...] tinha risos nos lábios, enquanto todo o seu corpo estremecia num choro doloroso e confuso. Chorava, ria, resmungava. Desfiava fios retorcidos de uma longa história. Andava em círculos, ora com uma das mãos fechada e com o braço para trás, como se fosse cotoco, ora com as duas palmas abertas, executando calmos e ritmados movimentos, como se estivesse moldando alguma matéria viva. Todo cuidado Ponciá Vicêncio punha nesse imaginário ato de fazer. Com o zelo da arte, atentava para as porções das sobras, a massa excedente, assim como buscava ainda significar as mutilações e as ausências que também conformam um corpo. Suas mãos seguiam reinventando sempre e sempre. E quando quase interrompia o manuseio da arte, era como se perseguisse o manuseio da vida, buscando fundir tudo num ato só, igualando as faces da moeda. Seus passos em roda se faziam ligeiramente mais rápidos então, sem contudo se descuidar das mãos. 
Andava como se quisesse emendar um tempo ao outro, seguia agarrando tudo, o passado-presente-e-o-que-há-de-vir.

E do tempo lembrado e esquecido de Ponciá Vicêncio, uma imagem se presentificava pela força mesma do peso de seu vestígio: Vô Vicêncio. Do peitoril da pequena janela, a estatueta do homembarro enviesada olhava meio para fora, meio para dentro, também chorando, rindo e assistindo a tudo.

Lá fora, no céu cor de íris, um enorme angorô multicolorido se diluía lentamente, enquanto Ponciá Vicêncio, elo e herança de uma memória reencontrada pelos seus, não se perderia jamais, se guardaria nas águas do rio. ${ }^{77}$

O desfecho pessimista - e de certa forma passivo - do romance revela muito da realidade sócio-cultural brasileira. Comparado com os demais trabalhos de autoras afroamericanas contemporâneas e, mais especificamente, com aquele de Alice Walker também objeto deste estudo - Ponciá Vicêncio ilustra a polêmica afirmação de Fredric Jameson acerca da literatura produzida no terceiro mundo:

(As) Western readers whose tastes (and much else) have been formed by our own modernisms, a popular or socially realistic third-world novel tends to come before us, not immediately, but as though already-read. We sense, between ourselves and this alien text, the presence of another reader, of the Other reader, for whom a narrative, which strikes us as conventional and naïve, has a freshness of information and a social interest that we cannot share $[\ldots]^{78}$

\footnotetext{
${ }^{77}$ Ibid. p. 132.

${ }^{78}$ JAMESON, F. Third world literature in the era of multinational capitalism. In: Social Text 15. 1986. p. 65-88.

"Como leitores ocidentais cujos gostos (e muito mais) foram formados por nossos próprios modernismos, um romance popular ou socialmente realista do terceiro mundo tende a se apresentar, não diretamente, mas como se fosse já lido. Nós sentimos, entre nós e o texto estrangeiro, a presença de um outro leitor, do Outro leitor, para quem uma narrativa, que nos soa como convencional e ingênua, tem um frescor de informação e um interesse social que nós não podemos compartilhar." (Tradução minha)
} 
O romance de Conceição Evaristo a situa em um contexto revelador do descompasso da cultura brasileira no que se refere às questões de raça e gênero. No desenrolar do romance percebe-se o empenho da autora em apresentar as causas históricas, sociais, políticas e econômicas para o racismo que acompanha a sociedade brasileira há séculos. O mesmo não acontece, porém, em termos de reivindicações e de propostas de meios para combatê-lo: seus personagens não assumem uma posição de enfrentamento da sociedade que os oprime e nem vislumbram uma forma de quebrar o círculo vicioso no qual estão inseridos.

O comportamento da classe média branca é aceito e, de certa maneira até justificado, e as propostas dirigidas aos afro-descendentes são aquelas de cunho emocional. Assim, a narrativa é permeada por sentimentos, sensações e emoções, que são a mola mestra do processo de construção e desenvolvimento dos personagens ao longo de todo o romance.

A autora merece crédito por promover uma inversão do papel do herói na narrativa. Em sua maioria, os heróis românticos têm uma trajetória permeada por desafios e lutas que levam ao crescimento emocional e/ou material e à vitória - seja ela simbólica ou não - no final da jornada. ${ }^{79}$ Este não é o caso da heroína de Conceição Evaristo: a trajetória de Ponciá é feita de perdas e derrotas sucessivas, que atingem seu ápice com a loucura que dela se apodera no desfecho do romance.

Tal inversão na trajetória do herói, porém, remete às limitações impostas pela ideologia brasileira, cuja elite é muito eficiente no sentido de desarticular movimentos de reivindicações. Dentro deste raciocínio é natural a presença de heróis fracassados que, frutos da política de contenção pela marginalização, não conseguem vislumbrar maneiras de enfrentar o sistema.

\footnotetext{
${ }^{79}$ A este respeito, ver VOGLER, Christopher. A jornada do escritor. Rio de Janeiro: Ampersand, 1992. $360 \mathrm{p}$.
} 
Aqui também se comprova a propriedade dos escritos de Roberto Schwarz acerca da ideologia do favor e do paternalismo, ainda tão presentes na sociedade brasileira, e suas perversas conseqüências:

A redução [...] reflete o funcionamento possível da cultura oitocentista numa sociedade que aparta da civilização grande parte de seus membros, quando não os mantém na senzala, ao passo que outra boa parte, embora inserida e desejosa de participar, não dispõe da independência pessoal necessária às opiniões próprias. ${ }^{80}$

[...] o aspecto encasacado, melhor-que-os-outros, antidemocrático, ou, em suma, o laço de origem entre a liberdade e a propriedade burguesa [...] existe e até hoje não se esgotou por completo em parte alguma. ${ }^{81}$

\subsection{UM PARALELO}

Publicado trinta e três anos depois de The Third Life of Grange Copeland, Ponciá Vicêncio nos convida a algumas reflexões acerca das sociedades norteamericana e brasileira.

\footnotetext{
${ }^{80}$ SCHWARZ. R. Duas meninas. São Paulo: Companhia das Letras, 1997. 144 p. p. 22.

${ }^{81}$ Ibid. p. 23.
} 
The Third Life of Grange Copeland é o primeiro romance escrito por Alice Walker, publicado quando a autora tinha vinte e seis anos de idade e estava profundamente envolvida com o Movimento Pelos Direitos Civis, transitando em suas fileiras como militante engajada e ativa. A sensação de pertencimento a um grupo guiado pelo ideal da luta para a transformação da sociedade criava a ilusão de que, naquele momento, os jovens, principalmente os estudantes negros, eram os agentes do processo de mudança histórica. ${ }^{82}$ Teorias antiimperialistas e defensoras da descolonização de países do terceiro mundo injetavam um ânimo ainda maior ao movimento.

É neste período, também, que o conceito de identidade cultural ganha força, promovendo "o descentramento conceitual do sujeito cartesiano e sociológico" (Hall, 2001, p. 45) e instaurando o conceito de identidade social, estreitamente vinculado aos novos movimentos sociais daquele período e por eles gerado:

Cada movimento apelava para a identidade social de seus sustentadores. Assim, o feminismo apelava às mulheres, a política sexual aos gays e lésbicas, as lutas raciais aos negros, o movimento antibelicista aos pacifistas, e assim por diante. Isso constitui o nascimento histórico do que veio a ser conhecido como a política de identidade - uma identidade para cada movimento. ${ }^{83}$

Neste contexto, a narrativa de Alice Walker apresenta-se não só como uma análise crítica dos profundos problemas decorrentes das relações desiguais entre brancos e negros, mas também como um manifesto otimista, que vislumbra a possibilidade de

\footnotetext{
${ }^{82}$ De certo modo, eles até poderiam ser, em função do vácuo estabelecido pela crise da esquerda nos EUA e da crise econômica, social, moral e política sem precedentes que atingia o país e cujo apogeu foi a queda do governo de Richard Nixon, em 1974.

${ }^{83}$ HALL, S. A identidade cultural na pós-modernidade. Rio de Janeiro: DP\&A, 2001. 102 p. p. 45.
} 
grandes alterações na conduta e na condição social da população negra. Assim, não por acaso, neste romance todas as esperanças de renovação concentram-se na jovem Ruth, que teve sua personalidade construída e fortalecida através da conscientização e conseqüente libertação do avô, Grange Copeland. Some-se a isso o fato de Ruth simbolizar a coragem, a ousadia e a determinação, características inerentes à juventude, necessárias para a realização de tal projeto.

A heroína de Conceição Evaristo surge em um momento em que as questões identitárias já perderam muito de sua importância no primeiro mundo, onde passam por um momento de reavaliações e redefinições.

Stuart Hall concebe a identidade cultural do sujeito pós-moderno como sendo fragmentada e multifacetada, composta de contradições, dúvidas e deslocamentos. ${ }^{84}$ Tal fragmentação concretizou-se através de um processo que teve seu início com o advento do capitalismo, cujo princípio de economia de mercado já abarcava a noção de relações comerciais mundiais, e atingiu seu apogeu com a comunicação imediata e constante entre todos os povos do mundo. "Essas novas características temporais e espaciais, que resultam na compressão de distâncias e de escalas temporais, estão entre os aspectos mais importantes da globalização a ter efeito sobre as identidades culturais." (Hall, 2001, p. 68.)

Este processo, que dá origem a comportamentos homogêneos nos quatro cantos do mundo, obviamente estimulados pelos países política e economicamente mais fortes, promove também o enfraquecimento e a descaracterização das identidades nacionais.

A questão da identidade nacional é outro aspecto relevante para o momento atual. Ainda segundo Stuart Hall, a identidade nacional não é inerente ao indivíduo, mas sim uma construção. Ela é realizada através do ensino de fatos históricos, do culto a

\footnotetext{
${ }^{84}$ Ibid.
} 
fatos e a personagens marcantes do país, da exaltação de características comportamentais e morais de seu povo, bem como de seu posicionamento perante a vida e o mundo.

Em um país periférico como o Brasil, desde sua origem suscetível às influências do centro - embora sempre com anos de atraso - a tarefa de Conceição Evaristo revelase bastante complexa e delicada. Sua narrativa surge em um momento em que a busca da construção da identidade cultural revela-se como uma empreitada fadada ao fracasso. Além das grandes transformações econômicas e históricas ocorridas mundialmente das quais o Brasil não pode ficar isento - a sociedade brasileira tem uma cultura profundamente assentada nos conceitos de democracia racial e do homem cordial, que se configuram como elementos fundamentais da formação da identidade nacional brasileira.

Sua narrativa gira em torno de uma família que tenta, sem sucesso, ter acesso às condições mínimas para que se atinja a cidadania. Começando pela educação, verificamos que tanto Ponciá quanto o irmão conseguem ser alfabetizados por caminhos tortos e devido a muita persistência, pois não tiveram acesso à educação formal. Em sua ingenuidade, não conseguiam enxergar a crueldade de um sistema que nega aos menos favorecidos os mesmos direitos que prega como sendo fundamentais para o seu desenvolvimento.

A religião, presente no romance através da exposição do sincretismo religioso brasileiro, fortemente marcado por rituais africanos, é apresentada como elemento consolador para problemas sociais e materiais e como solução para problemas de saúde, substituindo os cuidados médicos a que a população faz jus. É através da figura de Deus, santos, orixás e "encostos" que situações adversas são apresentadas, mediadas e trabalhadas para serem amenizadas ou eliminadas. É também através do sincretismo que 
é apresentado o lado simpático da vida popular brasileira, fato este que remete a algumas considerações sobre o tema apresentadas por Sérgio Buarque de Holanda em Raízes do Brasil:

[...] uma transposição característica para o domínio do religioso desse horror às distâncias que parece constituir, ao menos até agora, o traço mais específico do espírito brasileiro. Note-se que ainda aqui nós nos comportamos de modo perfeitamente contrário à atitude já assinalada entre japoneses, onde o ritualismo invade o terreno da conduta social para dar-lhe mais rigor. No Brasil é precisamente o rigorismo do rito que se afrouxa e se humaniza.

Essa aversão ao ritualismo conjuga-se mal - como é fácil imaginar - com um sentimento religioso verdadeiramente profundo e consciente. [...]

[...] A uma religiosidade de superfície, menos atenta ao sentido íntimo das cerimônias do que ao colorido e à pompa exterior, quase carnal em seu apego ao concreto e em sua rancorosa incompreensão de toda verdadeira espiritualidade; transigente, por isso mesmo que pronta a acordos, ninguém pediria, certamente, que se elevasse a produzir qualquer moral social poderosa. Religiosidade que se perdia e se confundia num mundo sem forma e que, por isso mesmo, não tinha forças para lhe impor sua ordem. Assim, nenhuma elaboração política seria possível senão fora dele, fora de um culto que só apelava para os sentimentos e os sentidos e quase nunca para a razão e a vontade. Não admira pois, que nossa República tenha sido feita pelos positivistas, ou agnósticos e nossa Independência fosse obra de maçons. [...] ${ }^{85}$

A quase impossível relação solidária entre negros e brancos nos Estados Unidos se faz presente no romance através da relação amistosa de Ponciá com sua patroa e de

\footnotetext{
${ }^{85}$ HOLANDA, Sérgio Buarque. Raízes do Brasil. Rio de Janeiro: José Olympio, 1975. 155 p. p. 110 111.
} 
Luandi com os policiais e com o delegado do distrito policial onde trabalha. No último caso, a ambigüidade das relações raciais brasileiras se faz presente nos conselhos dados pelo delegado a Luandi, então emocionalmente abalado pelo assassinato de sua namorada:

Que Luandi fosse a zona sim, afinal era homem e ainda por cima solteiro, mas que fizesse igual ao Soldado Nestor. Fosse lá, derramasse o que não se podia guardar e voltasse são e liso. Nada de gostar de mulher-dama. Ele dera até sorte, pois Negro Climério poderia ter feito o mesmo com ele também. E que Luandi não levasse a mal o que ele ia dizer, mas quase todo negro era vagabundo, baderneiro, ladrão e com propensão ao crime. Poucos, muito poucos, eram como o Soldado Nestor e ele. (grifo nosso) ${ }^{86}$

A independência e o progresso buscados pela família Vicêncio, marcadamente por Ponciá e Luandi, não é alcançada em função da própria complexidade da realidade cultural e social brasileira. O mito do homem cordial - criado a partir de um desvirtuamento do conceito original para atender os interesses do dominador e que carrega como apêndice o também mito do racismo cordial - encobre relações perversas de dominação e exclusão que vêm sistematicamente mantendo a grande maioria da população afro-descendente à margem da sociedade, sem voz e alijada de seus direitos básicos.

O próprio fato de situar Ponciá em uma favela na periferia de uma grande cidade já revela a impossibilidade de se constituir uma identidade cultural: a favela é o local que sintetiza todas as injustiças da sociedade brasileira, o local que abriga e denuncia a ausência dos requisitos básicos da cidadania. É nela que encontramos centenas de

\footnotetext{
${ }^{86}$ Op. cit. P. $120-121$.
} 
milhares de Ponciás e Luandis, "sujeitos monetários sem dinheiro", forjados em velocidade assustadora pela sociedade contemporânea e impossibilitados de serem sujeitos da própria história.

A complexidade do tema abordado pela autora tem reflexos diretos na forma do romance. Ao apresentar um núcleo de personagens negros em busca da identidade cultural em pleno século XXI, Conceição Evaristo se depara com todas as dificuldades impostas pela sociedade pós-moderna. Regida pelo capitalismo em estágio avançado e predatório, responsável por uma nova forma de desenvolvimento das relações interpessoais - marcadamente alienadas e coisificadas - e tendo como meta primordial o lucro e o consumo, esta sociedade só pode forjar indivíduos cuja identidade seja fragmentada, multifacetada e, portanto, contraditória e inacabada. Some-se a isso a complexidade da conformação da sociedade brasileira, dividida entre o "politicamente correto" e a realidade, onde o preconceito racial não abre espaço para a aceitação e a acolhida das diferenças.

Estas observações remetem ao modo como o romance foi construído: Ponciá Vicêncio é uma narrativa intimista, emotiva, repleta de imagens, lembranças e sensações que chegam ao leitor de maneira fragmentada e atemporal, sem grandes enfrentamentos e sem apontar soluções factíveis para os problemas apresentados. É um romance que vem a confirmar a força que a imagem do Brasil como um "paraíso racial" tem sobre o caráter e o comportamento dos indivíduos e, neste sentido, confirma também a propriedade do conceito Adorniano de que "forma é conteúdo sócio-histórico decantado". 


\section{LIMITES}

[...] Ora, em que consiste o racismo? Em converter em "natureza" o que é apenas "cultural", ou, com outras palavras, em converter o fato social em objeto metafísico, em "essência" intemporal. Para justificar, para legitimar o domínio e a espoliação, o colonizador precisa estabelecer que o colonizado é por "natureza", ou por "essência", incapaz, preguiçoso, indolente, ingrato, desleal, desonesto, em suma, inferior. Incapaz, por exemplo, de educar-se, de assimilar a ciência e a tecnologia modernas, bem como de exercer a democracia, de governar-se a si mesmo. $[\ldots]^{87}$

Ambos os romances estudados neste trabalho apresentam a temática do racismo, invariavelmente apontado como a origem do sofrimento e do fracasso emocional, material e social de várias gerações de afro-descendentes. Ambos os romances têm em

\footnotetext{
${ }^{87}$ CORBISIER, Roland. Prefácio. In: MEMMI, Albert. Retrato do colonizado precedido pelo retrato do colonizador. São Paulo: Paz e Terra, 1989. 127p.
} 
comum, também, o fato de terem sido criados por mulheres negras. São, portanto, reflexões provenientes de quem viveu a complexidade do mundo dos oprimidos e, fazendo uso do contexto social dos excluídos, retratam o mundo desolado e carente que os cerca.

O que as diferencia é o fato de serem nativas de países diferentes: uma é norteamericana, e a outra, brasileira. É justamente este fato, porém, que reveste de importância a análise comparativa de suas obras, pois, embora Brasil e Estados Unidos da América tenham vivenciado na mesma época a escravidão de negros trazidos da África, cada país teve suas peculiaridades tanto durante a vigência do sistema escravocrata quanto no processo de abolição da escravidão e seus desdobramentos.

Partindo do princípio de que o racismo é uma construção cultural, as diferenças históricas entre os dois países evidentemente levaram à formação de sociedades cuja concepção das relações raciais foi moldada de forma distinta.

O regime escravocrata norte-americano era regional; somente os estados do sul mantinham o trabalho escravo em suas "plantations", enquanto que o norte do país fazia uso da mão-de-obra assalariada no comércio e na indústria.

No Brasil o quadro era bastante diferente, visto que todo o país fazia uso da mão-de-obra escrava, voltada fundamentalmente para o trabalho na lavoura em função das próprias características do país naquele período, com uma economia fortemente agrícola.

Esta diferença é significativa, pois teve reflexos importantes no processo de extinção da escravidão nos dois países. Para começar, como aponta a pesquisadora Célia Maria M. Azevedo, o posicionamento dos abolicionistas norte-americanos e brasileiros era marcadamente diferente: 
[...] Os abolicionistas americanos não viviam numa sociedade escravista; aqueles que alguma vez viveram no sul escravista [...] mudaram-se para o norte para nunca mais voltar. Ao descrever o contraste entre as instituições livres do norte e o sul escravista, os abolicionistas puderam engendrar uma reivindicação de mudança apartada dos interesses escravistas. Os abolicionistas brasileiros, por seu turno, viviam no seio de uma sociedade escravista. Ao criticar a escravidão, eles o faziam com uma atenção solícita aos interesses dos fazendeiros, os quais eram vistos como parte integrante dos interesses da nação como um todo. ${ }^{88}$

Outro aspecto importante é a formação cultural dos abolicionistas dos dois países e a maneira como esta influiu na articulação e na manifestação de seus princípios. Os abolicionistas norte-americanos, negros ou brancos, concentrados principalmente no norte do país, dialogavam com seus pares e foram, assim, capazes de construir um discurso afinado, que invocava tanto razões religiosas quanto políticas para justificar suas posições:

[...] Seria interessante saber até que ponto o abolicionismo americano teria se desenvolvido de modo tão radical se não fossem as pontes intelectuais que ligavam os abolicionistas brancos e negros nos estados do norte. Embora uns e outros vivessem em comunidades crescentemente segregadas, é possível afirmar que os abolicionistas, a despeito de suas distintas origens, foram capazes de se comunicar intelectualmente ao expressar suas opiniões e sentimentos com base em três textos fundamentais: a Bíblia, a Declaração de Independência e a Constituição. E [...] os abolicionistas de ascendência africana nunca perdiam a chance de lembrar aos seus pares de ascendência

${ }^{88}$ AZEVEDO, Célia M. M. Abolicionismo: Estados Unidos e Brasil, uma história comparada (século XIX). São Paulo: Annablume, 2003. p. 203. 253 p, 
européia que eles eram irmãos por criação divina e também herdeiros das promessas igualitárias da Revolução Americana. ${ }^{89}$

O mesmo não acontecia no Brasil. Nossos abolicionistas, imbuídos de uma cultura que pretendia ser uma réplica da cultura européia, membros da classe governante, sem nenhuma ligação com a população negra além daquela de dominação presente nas relações de trabalho e nos negócios lucrativos advindos desta relação, viam a abolição como uma questão prática, ligada à necessidade de se modernizar o país a fim de que ele pudesse alcançar um status superior, mais próximo dos padrões europeus.

[...] O abolicionismo americano contava com fundamentos religiosos, o que explicaria, em parte, porque as lutas contra a escravidão e pelos direitos de cidadania para o negro desenvolviam-se sempre de forma entrelaçada. Já o abolicionismo brasileiro, imbuído de uma ênfase secular, abordava o problema da escravidão de um modo mais pragmático e menos principista. Os abolicionistas brasileiros tendiam mais a enfatizar a necessidade de ultrapassar o atraso e alcançar o progresso nacional do que a promover qualquer política de reparação voltada para os ex-escravos e seus descendentes. Era, portanto, da perspectiva da classe dos fazendeiros, dos proprietários e profissionais urbanos que os abolicionistas pensavam a questão do progresso. $[\ldots]^{90}$

Fruto de posicionamentos tão discrepantes, a Abolição da Escravidão nos dois países teve desdobramentos igualmente díspares. Embora o racismo na cultura americana já fosse praticado nas relações étnicas no norte do país, onde os negros livres eram crescentemente privados dos direitos desfrutados pela população branca, as ações praticadas pelo governo e por associações humanitárias no período imediatamente

\footnotetext{
${ }^{89}$ Ibid., p. 203.

${ }^{90}$ Ibid., p. 202.
} 
posterior à Abolição foram decisivas para que os ex-escravos pudessem recomeçar suas trajetórias no seio daquela sociedade.

\begin{abstract}
O abolicionismo nos Estados Unidos e no Brasil terminou tal como se iniciou, ou seja, às voltas com questões muito distintas. Às vésperas da abolição, reconstrução era a palavra que melhor descrevia as intenções dos abolicionistas americanos. Já as intenções dos abolicionistas brasileiros seriam melhor abarcadas pela palavra transição. ${ }^{91}$
\end{abstract}

Determinante, também, para o futuro dos escravos recém-libertos nos dois países foi a forma como conquistaram a liberdade.

A Abolição da Escravidão norte-americana aconteceu após quatro anos de Guerra Civil (1861-1865), período sangrento da história do país. Embora a libertação dos escravos não fosse a única e principal causa da luta entre o norte e o sul do país (questões relativas ao poder econômico e político das duas regiões estavam fortemente presentes), foi somente com a derrota do sul "escravista" para o norte "democrático" que os afro-descendentes conquistaram a condição de homens livres.

Neste contexto, as políticas de reconstrução criadas pelo governo norteamericano visavam basicamente promover a recuperação dos estados do sul, que tiveram sua infra-estrutura econômica seriamente abalada durante a guerra, e, assim, manter a unidade da nação. Porém, com uma população majoritariamente negra, a educação e a preparação desta mão-de-obra para o trabalho produtivo na região se faziam absolutamente necessárias. É nesta esteira que se seguem as políticas de reparação e de amparo aos recém-libertos.

\footnotetext{
${ }^{91}$ Ibid., p. 199.
} 
Assim, durante o período de 1865 a 1877 foi criada toda uma rede de apoio aos ex-escravos, financiada pelo Governo Federal, cujos expoentes foram o Freedmen's Bureau (1865-1872) e as igrejas cristãs negras. Concebida inicialmente com o objetivo de oferecer assistência social, esta instituição, que mais tarde se juntou a organizações religiosas e filantrópicas, facilitava o acesso da população negra à educação, à proteção legal e à ajuda econômica.

O acesso à educação foi significativo, e os afro-descendentes, que acreditavam que a chave para se alcançar o desenvolvimento pessoal estava na educação formal, tiraram proveito desta oportunidade. Foi também neste período que, com a ajuda do Freedmen's Bureau, foram criadas várias universidades negras, sendo as mais notáveis as Universidades Fisk, Howard e Atlanta.

Embora este período de apoio e encaminhamento tenha sido curto, pois o sistema rapidamente começou a criar leis que promoviam a segregação racial, além de tolerar a formação de organizações secretas como a temida Ku Klux Klan - responsáveis por assassinatos, linchamentos, estupros e espancamentos da população negra - ele deixou um legado muito importante: foram os descendentes desta geração que, anos mais tarde, puderam se articular e lutar pela conquista de direitos civis de sua comunidade.

No Brasil, a escravidão teve seu fim decretado com a assinatura de uma lei que nada mais fez do que tornar legal uma situação já existente - o movimento de abandono das fazendas realizado pelos escravos - e que atendia plenamente os anseios da elite econômica brasileira que já havia percebido que a mão-de-obra escrava não era mais lucrativa como havia sido durante tantos anos. Um negócio de brancos para benefício dos brancos. 
A escravidão terminou subitamente no Brasil em 13 de maio de 1888 [...] Mas como Ruy Barbosa observou alguns meses depois, não havia nada mais a ser feito. $\mathrm{O}$ fim da escravidão tornou-se um fato através do movimento do "não quero" dos escravos, com centenas deles simplesmente se retirando das fazendas ao final de 1887 e início de 1888. Devido às circunstâncias criadas pelos próprios escravos, a transição deixou de ser uma palavra-chave para os abolicionistas. Assim, o abolicionismo simplesmente se extinguiu em meio às muitas comemorações de rua, festas públicas e banquetes que se seguiram à assinatura da lei no Parlamento. ${ }^{92}$

A sociedade brasileira não dispensou maiores cuidados ao escravo recém-liberto, visto que não estava preocupada com a sua adaptação à nova realidade. Na verdade, sua condição marginalizada era bastante interessante ao sistema, que poderia empregá-lo como mão-de-obra barata, agora sem a necessidade de provê-lo com moradia, vestuário ou alimentação.

A desagregação do regime escravocrata e senhorial operou-se, no Brasil, sem que se cercasse a destituição dos antigos agentes de trabalho escravo de assistência e garantias que os protegessem na transição para o sistema de trabalho livre. Os senhores foram eximidos da responsabilidade pela manutenção e segurança dos libertos, sem que o Estado, a Igreja ou outra qualquer instituição assumissem encargos especiais, que tivessem por objeto prepará-los para o novo regime de organização da vida e do trabalho. O liberto viu-se convertido, sumária e abruptamente, em senhor de si mesmo, tornando-se responsável por sua pessoa e por seus dependentes, embora não dispusesse de meios materiais e morais para realizar essa proeza nos quadros de uma economia competitiva. ${ }^{93}$

\footnotetext{
${ }^{92}$ Ibid., p. 201-202.

${ }^{93}$ FERNANDES, Florestan. A integração do negro na sociedade de classes. São Paulo: Dominus, 1965. p.1
} 
Ao transformar-se juridicamente em homem livre, o agora "cidadão negro" deparou-se com uma sociedade desprovida de leis e programas de orientação para recebê-lo e prepará-lo para a nova vida. Viu-se repentinamente sem habitação, alimentação e trabalho. Ironicamente, foram os ex-proprietários de escravos que se julgaram desamparados e pleitearam indenizações do Governo Federal para ressarcir as perdas financeiras acarretadas pela extinção do trabalho escravo.

São exatamente os descendentes desta geração que ganham vida e são retratados por Alice Walker e Conceição Evaristo em seus respectivos romances.

A escritora americana apresenta uma sucessão de atos de violência física e psicológica praticados tanto por brancos contra negros quanto por negros contra seus pares, mais especificamente contra a própria família.

O homem branco, detentor do poder e, conseqüentemente, explorador econômico, aparece na narrativa na figura do proprietário de terras e de seus capatazes. Embora apareça vagamente, nos momentos em que o narrador tem a intenção de mostrar as relações de poder e submissão, sua figura é materializada através dos personagens Mr. Shipley, Mr. J. L. e Captain Davis. Eles não são personagens plenamente desenvolvidos, mas sua presença é importante na medida em que são materializados e estabelecem um contraponto, escancarando a exploração predatória do trabalho dos colonos das fazendas pelas quais Grange e Brownfield Copeland, acompanhados de suas respectivas famílias, passaram.

Eles são apresentados pela autora como representantes de um sistema sócioeconômico que prima pela acumulação do capital, ainda de forma modesta no sul do país, através do trabalho na lavoura, em detrimento da oferta de condições mínimas de subsistência digna aos trabalhadores de cuja mão-de-obra extraem seu lucro. 
O recorte abaixo ilustra, de forma precisa, as relações de dominação com vistas ao lucro apresentadas pela autora: um diálogo entre o patrão e Brownfield logo após o funeral de sua mãe e seu irmão.

"You can get yourself a wife," said Shipley confidentially, "and settle down here in the same house. It might need a little fixing up, but I could lend you enough for that, and with a few licks here and there it ought to be good as new."

Shipleys's hair was still like that of a sleek greasy animal, but now it was dingy white and thin. He looked at Brownfield from under brows that had faded from blond to yellowish-gray. His pale blue eyes struggled to convey kindness and largesse. Brownfield slid down from the truck knowing his face was the mask his father's had been. Because this frightened him and because he did not know why he should have inherited this fear, he studiedly brushed imaginary dust from the shoulders of a worn black suit Shipley had given him.

He had been shocked to see Shipley at the funeral, but soon guessed he had come hoping to catch Grange. Shipley did not take kindly to people running off owing him money, no matter that they had paid off whatever debts they might have owed many times over. Nobody had whispered a word against him while he stood looking down on the bloatedly sleeping mother and child. To most of the people at the funeral Shipley's presence was a status symbol and an insult, though they were not used to thinking in those terms and would not have expressed such a mixed feeling. Shipley squeezed out a tear for the benefit of the other mourners, and Brownfield had chuckled bitterly to himself. [...]

[...] He knew too that the minute he accepted money from Shipley he was done for. If he borrowed from Shipley, Shipley would make sure he never finished paying it back.

"Don't know but what we might can build you a new house," said Shipley, thinking that with Brownfield's muscles he could do a grown man's work. Shipley believed with a mixture of awe and contempt that blacks developed earlier than whites, especially in the biceps. He 
thought too that as long as he had Brownfield there was a chance of getting Grange. Believing that Brownfield was choked up from grief and from his generous offer Shipely continued speaking to him on an encouraging plane.

"After all, if you marry one of these little fillies on my place she's going to want to smell some new wood. [...]"

[...] He fished about for sympathy, while Brownfield stood looking at the ground.

"But the main thing is" - Shipley smiled kindly - "we want you to stay here with us. And we don't hold it against you what your daddy done. We'll just wipe that off the books." He continued to smile but eyed Brownfield shrewdly from under his brows. "Of course, I believe you said you didn't know which way he was headed?" "No, sir," said Brownfield, from a great hollow distance.

"Well," said Shipley sadly, as if a great wrong were being done him but one which he would not allow to dissuade him from future acts of kindness, "you think about all we discussed. And take the day off and get yourself straightened out. I tell you this much, I think we going to work out fine; and I know my boys will be glad to have somebody they already know to work with them when they take over Shipley's Farm and Bait." [...] "You and me will start out fresh," he said, "and remember, the North ain't all people say it is. Just remember that." 94

\footnotetext{
${ }^{94}$ WALKER, Alice. The third life of Grange Copeland. New York: Harcourt Books, 2003. p. 27-29. "Você pode arrumar uma esposa", Shipley disse confidencialmente, "e se instalar aqui na mesma casa. Ela poderia precisar de um pouco de reparos, mas eu poderia te emprestar o suficiente para fazer isso, e com alguns reparos aqui e acolá ela ficaria como nova."

$\mathrm{O}$ cabelo de Shipley ainda era como aquele de um delicado animal gorduroso, mas agora ele estava fino e manchado de branco. Ele olhava para Brownfield sob sobrancelhas que tinham desbotado de louro para cinza amarelado. Seus pálidos olhos azuis lutavam para transmitir bondade e gentileza. Brownfield escorregou para fora do caminhão sabendo que seu rosto era a máscara que o rosto do seu pai havia sido. Porque isso o amedrontava e porque ele não sabia por que deveria herdar este medo, ele propositalmente tirou uma poeira imaginária dos ombros do terno preto que Shipley havia lhe dado.

Ele havia ficado chocado ao ver Shipley no funeral, mas logo supôs que ele havia ido na esperança de encontrar Grange. Shipley não era simpático a pessoas que fugiam lhe devendo dinheiro, não importa que eles tivessem pago repetidas vezes qualquer débito que tivessem. Ninguém havia sussurrado uma palavra contra ele enquanto ele olhava para mãe e filho inchados, que repousavam. Para a maioria das pessoas no funeral a presença de Shipley era um símbolo de status e um insulto, embora eles não estivessem acostumados a pensar nestes termos e não teriam expressado tais sentimentos confusos. Shipley espremeu uma lágrima para se solidarizar com os outros e Brownfield riu-se amargamente [...]

[...] Ele sabia também que no minuto em que aceitasse dinheiro de Shipley ele estaria perdido. Se ele emprestasse dinheiro de Shipley, Shipley se certificaria de que ele nunca terminasse de pagar o empréstimo.

"Não sei, mas nós poderíamos construir uma casa nova para você." disse Shipley, pensando que os músculos de Brownfield poderiam realizar o trabalho de um adulto. Shipley acreditava com uma mistura de medo e desprezo que os negros se desenvolviam mais cedo do que os brancos, especialmente os
} 
Os tentáculos deste sistema atingem todos os aspectos da vida da população negra e a sua formação escolar não é, evidentemente, exceção. As crianças negras daquela geração de lavradores recebiam educação escolar - como prescrito pelas leis de um país "democrático" - porém, de forma precária. Alunos de diferentes séries eram agrupados em uma mesma sala, de forma a haver doze séries do ensino fundamental distribuídas por três salas de aula, com uma professora polivalente regendo as aulas de cada agrupamento. Os poucos livros utilizados pelas crianças eram livros usados doados pelas escolas brancas. Neles, a ideologia da supremacia racial branca estava presente, como pode ser observado no recorte abaixo:

[...] Today she (Ruth) looked at the new world history book the classes had been given that morning. [...] Before they got it from the white school they hadn't had a history book. [...] But then she opened the cover, not the pages of the book, but the cover, before the pages began. On the right-hand side of the book there was another girl's name, Jacqueline Paine, and under her name was written Baker County Elementary School, the name of the white school. All their books came from there so this did not surprise her. But then she looked down at the rest of the page and gasped. For on this page and across the entire front inside covering of the book was a huge spread

bíceps. Ele pensava também que enquanto ele tivesse Brownfield havia uma chance de pegar Grange. Acreditando que Brownfield estava sufocado de tristeza e com a sua generosa oferta Shipley continuava falando com ele com um plano encorajador. "Afinal de contas, se você se casar com um destes pequenos lírios do meu pedaço ela vai querer sentir o cheiro de madeira nova. [...] Ele buscava simpatia, enquanto Brownfield continuava olhando para o chão. "Mas a coisa mais importante é" - Shipley sorria amavelmente - "nós queremos que você fique aqui conosco. E nós não culpamos você pelo que o seu pai fez. Nós simplesmente apagaremos os livros." Ele continuava a sorrir mas observava Brownfield astutamente por sob as suas sobrancelhas. "Claro, eu creio que você disse que não sabia para que lado ele foi?" "Não, senhor," Brownfield disse de uma distância profunda. "Bem," disse Shipley tristemente, como se um grande mal tivesse sido feito a ele, mas que não o dissuadiria de futuros atos de bondade, "pense sobre tudo que falamos. E tire o dia de folga para se recuperar. Eu te digo, eu acho que nós vamos nos entender bem; e eu sei que os meus meninos ficarão felizes em ter alguém que já conhecem para trabalhar com eles quando eles assumirem a "Shipley's Farm and Bait." [...] "Você e eu vamos começar do zero," ele disse, "e lembre-se, o norte não é tudo aquilo que as pessoas dizem. Apenas lembre-se disso." (Tradução minha) 
drawing called at the top in big green letters, "The Tree of the family of Man." And on this tree there were all kinds of people. At the top, in pale blue and yellow, there were the white people. Their picture showed them doing something with test tubes, the lettering on one of their jackets said "Scientist." Behind them were drawings of huge tall buildings and cars and trains and airplanes. Jacqueline Paine had written underneath their picture: Note: Americans, Germans, People who live in the extreme Northern part of Europe. In parentheses she had written (England). Below the "Americans" were people drawn in yellow, and they were wearing funny little straw hats and were driving huge water buffalo. Behind them were a lot of pretty small objects made of jade and bamboo. Under their picture Jacqueline Paine had written in her round script: Note: The Yellow Race. Chinese, Japanese, etc., and people who live far away from us, in the Far East. Beneath them was a drawing in red of American Indians. They were sitting placidly, one old man smoking a long feather-covered pipe. Some women were sitting next to him making beautiful rugs and pottery and baskets. Underneath their picture Jacqueline Paine had written: Note: Our own American Indians. We saved from disease and wild primitive life. Taught them useful activities as pictured above. They have also been known to make beads. But it was the last picture she saw on the page that made her gasp. For at the very bottom of the tree, not actually joined to it but emanating from a kind of rootless branch, there was the drawing of a man, in black, with fuzzy hair, fat grinning lips, and a bone sticking through his nose. He was wearing a grass skirt and standing over a pot of boiling water as if he expected, at any moment, a visiting missionary. Underneath his picture Jacqueline Paine, in her neat note-taking script, had written just one descriptive word. She did not even say whether he had made his own grass skirt. It leaped out at Ruth like a slap in the face. Note: A nigger. ${ }^{95}$

\footnotetext{
${ }^{95}$ Ibid., P. 238-240. [...] "Hoje ela olhava para o novo livro de história do mundo que as turmas haviam recebido naquela manhã. [...] Antes de ganhá-lo da escola dos brancos eles não haviam tido um livro de história. [...] Mas ela virou a capa, não as páginas do livro, mas a capa, antes que as páginas começassem. Do lado direito do livro estava o nome de outra garota, Jacqueline Paine, e sob o seu nome estava escrito Baker County Elementary School, o nome da escola dos brancos. Todos os seus livros vinham de lá, então isto não a surpreendeu. Mas então ela olhou para o resto da página e engasgou. Pois naquela página e em toda a primeira página do livre havia um grande desenho com um título no alto, em letras verdes, "A Árvore Genealógica do Homem" E naquela árvore havia todos os tipos de pessoas. No topo, em pálido
} 
Esta relação estreita entre o indivíduo e a sociedade, que determina seus movimentos, é uma constante na narrativa, promovendo uma articulação entre os momentos de transição individual e os momentos de transição histórica.

Seus reflexos são sentidos na forma como o romance foi construído: a narrativa segue uma ordem cronológica, como o são os acontecimentos históricos, com alguns flashbacks ligados à "segunda" vida de Grange em Nova Iorque, os personagens reagem a estímulos externos e há uma grande quantidade de descrições do espaço exterior - as plantações, as árvores, os pássaros, as casas, os jardins, as ruas, os prédios e até mesmo a descrição física dos personagens.

Apesar de responsabilizar diretamente o sistema sócio-econômico e seus representantes pelos infortúnios da população afro-descendente e colocar seu romance como um não à ideologia dominante, a autora coloca-se de forma a procurar aprofundar seu campo de visão e, deste modo, também promove um chamado aos homens e às mulheres negras de seu tempo.

azul e amarelo, estavam os brancos. Seu desenho os mostrava fazendo alguma coisa com tubos de ensaio, as letras em uma de suas jaquetas diziam "Cientista". Atrás deles havia desenhos de grandes e altos edifícios e carros e trens e aeroplanos. Jacqueline Paine tinha escrito debaixo da fotografia: Nota: Americanos, alemães, pessoas que vivem no extremo norte da Europa. Entre parênteses ela havia escrito (Londres). Abaixo dos "americanos" estavam pessoas pintadas de amarelo, e eles estavam usando engraçados chapeuzinhos de palha e estavam andando em um grande búfalo da água. Atrás deles havia muitos objetos bonitos e pequenos feitos de jade e de bambu. Sob seu desenho Jacqueline Paine havia escrito com sua letra redonda: Nota: A Raça Amarela. Chineses, Japoneses, etc., e pessoas que vivem muito distante de nós, no Oriente. Abaixo deles havia um desenho em vermelho dos índios americanos. Eles estavam sentados placidamente, um homem velho fumando um comprido cachimbo coberto de penas. Algumas mulheres estavam sentadas perto dele fazendo bonitos tapetes e cerâmica e cestos. Sob o seu desenho Jacqueline Paine havia escrito: Nota: Nossos próprios índios americanos. Nós os salvamos da doença e da vida selvagem. Ensinamos-lhes atividades úteis como demonstradas acima. Eles também são conhecidos por fazerem colares de contas, Mas foi a última foto que ela viu na página que a fez engasgar. Pois na base da árvore, não exatamente ligado a ela, mas derivando dela, havia o desenho de um homem, em preto, com cabelo pixaim, gordos lábios sorridentes, e um osso atravessado em seu nariz. Ele estava usando uma saia de mato e ao lado de um pote com água fervente, como se estivesse esperando, a qualquer momento, a visita de um missionário. Sob sua foto Jacqueline Paine, em sua primorosa anotação, tinha escrito apenas uma palavra descritiva. Ela nem mesmo dizia se ele havia feito sua saía de mato. Aquilo atingiu Ruth como um tapa na cara. Nota: Um Negro.” 
Inserida no contexto dos Estados Unidos da América dos anos sessenta do século passado como militante ativa do Movimento pelos Direitos Civis e contaminada pelo otimismo geral que motivava os jovens e apontava para grandes possibilidades de mudança, Alice Walker busca apresentar para seus pares soluções para os problemas por eles enfrentados. Assim, aponta para a necessidade de conscientização, construída principalmente através da educação formal, que irá gerar um fortalecimento da autoestima dos afro-descendentes e também fará com que assumam sua parte de responsabilidade na condução de suas vidas.

Embora em nenhum momento inocente o sistema das injustiças cometidas, a autora conclama seus pares a buscar estratégias de luta e de crescimento pessoal ao invés de aceitar seus fracassos através da justificativa de que os mesmos são impostos pelos outros. Ela aponta claramente a necessidade de se conhecer muito bem "o inimigo", comprometer-se através de postura e atitudes propositivas que irão impedir o indivíduo de se transformar naquilo que mais odeia, enfim, enxergar a vida como objeto de busca e de construção. No romance, Grange consegue mudar para melhor, embora através de um processo extremamente doloroso, mas o mesmo não acontece com Brownfield, e por isso ele é destruído tanto em termos materiais quanto em termos emocionais, pois se revela incapaz de construir uma vida plena e digna de ser vivida.

O posicionamento da autora reflete o cerne das relações raciais em seu país: à medida que os brancos sentiram a necessidade de se unir, a princípio para unificar a nação após a Guerra Civil (havia um forte antagonismo entre o Sul e os vitoriosos do Norte), e depois, com o início da luta de classes entre brancos decorrente do rápido crescimento econômico dos Estados Unidos da America, os negros, mais uma vez deixados à própria sorte, viram-se forçados a assumir sua identidade como grupo étnico e social: 
[...] O regionalismo, como "um tipo de guerra estrangeira sublimada", tinha de ser amenizado enquanto não pudesse ser totalmente eliminado. Em vez de impor sua autoridade, o Estado central simplesmente retirou-se, consolidando sua autoridade do melhor modo possível para evitar o agravamento do conflito. Os afro-americanos foram abandonados novamente, com a retórica de Lincoln de reconciliação nacional aplicada somente para brancos. Uma geração depois da Guerra Civil, Jim Crow ascendeu, uma política voltada tanto para a diminuição do conflito regional como para unificar os brancos do Sul. O antagonismo regional e a competição não desapareceram, mas foram vitoriosamente contidos e enquadrados em um só Estado. ${ }^{96}$

As políticas de segregação racial então implantadas, e praticadas por várias décadas, intensificaram a desigualdade social e reforçaram o sentimento de pertencimento a um grupo que se via cada vez mais impelido a reagir contra um sistema que ostensivamente os excluía de todas as maneiras possíveis. Foi assim, como um grupo coeso, que compartilhava as mesmas necessidades e tinha as mesmas reivindicações, que ganhou força e passou a exigir direitos civis iguais àqueles desfrutados pela população branca.

A conseqüência dos movimentos liderados pelos afro-descendentes foi uma espécie de "reorganização" social e racial na sociedade norte-americana - apoiada por políticos liberais e grandes corporações como uma forma de cooptar aquela vasta camada da população e inseri-la no mercado de trabalho, transformando-a, assim, em um grande nicho de consumidores - na qual uma grande parte da população negra teve

\footnotetext{
${ }^{96}$ MARX, Anthony W. A construção da raça no Brasil: comparações históricas e implicações políticas. In: SOUZA, Jessé (org.) Multiculturalismo e racismo: uma comparação Brasil - Estados Unidos. Brasília: Paralelo 15, 1997. 275 p.
} 
acesso aos bens materiais, originariamente associados à classe média branca, enquanto continuavam a ser considerados "diferentes".

Materializou-se, desta forma, a política de "separados, mas iguais”, previamente preconizada por Booker T. Washington na última década do século XIX, quando causou polêmica (foi acusado de apoiar a segregação e a discriminação racial) ao afirmar que os negros melhor protegeriam seus direitos constitucionais através do alcance do progresso moral e econômico. ${ }^{97}$

Em The third life of Grange Copeland verifica-se que esta filosofia está fortemente presente e que a forma "revolucionária" de emancipação apresentada na narrativa implica em aderir ao American way of life, o que significa aceitar a impossibilidade de sobrevivência daqueles que não se submetem à força bruta da realidade social daquele país. Embora a autora busque apresentar uma saída alternativa com a reclusão de Grange e Ruth nas terras a ele pertencentes e com a posterior sugestão de que Ruth partirá como uma militante do Movimento pelos Direitos Civis, seus esforços revelam-se ingênuos e utópicos, pois “os impulsos libertários são em todas as instâncias contidos pelo amplo sistema capitalista” (Willis, 1997, p. 96)

Do período em que Alice Walker produziu seu romance (1969) até os dias atuais não ocorreram grandes transformações na sociedade norte-americana no que se refere ao racismo e à integração do negro. "diferentes, mas iguais" é a política que permanece, e somente aqueles que conseguem alcançar a igualdade econômico-financeira podem se firmar como cidadãos norte-americanos.

No momento em que este estudo está sendo concluído o mundo comemora a eleição de Barack Obama para a presidência dos Estados Unidos da America. Tal comemoração deve-se a dois motivos principais: o primeiro deles é a necessidade de se

\footnotetext{
97 "In all things social we separate as the fingers, yet one as the hand in all things essential to mutual progress." In: LINDSEY, Howard O. A history of black America. London: Bison Books, 1994. 160 p.
} 
mudar os rumos da política do governo norte-americano, há quase uma década liderado pelo conservador Partido Republicano que, dentre outros desmandos, promoveu e financiou a guerra predatória em diversas partes do mundo e permitiu que se forjasse no país uma crise econômica gravíssima, de proporções muito próximas daquela acontecida nos anos vinte do século passado e que promoveu a Quebra da Bolsa de Nova Iorque em 1929, com reflexos em todo o mundo. O segundo motivo é o fato de Barack Obama ser um homem negro que, vencendo as barreiras sociais, graduou-se pela Universidade de Harvard, posteriormente foi eleito senador e agora se torna o primeiro presidente não branco de origem européia da maior potência políticoeconômica mundial.

Sua trajetória rumo à presidência dos Estados Unidos da América foi acompanhada com grande interesse, principalmente devido à sua origem racial. Considerado um homem negro em seu país - no Brasil seria classificado como mulato, pois é filho de mãe branca e pai negro - sua eleição significaria um grande avanço nas relações raciais norte-americanas.

Obama, porém, foi extremamente cauteloso, deixando que os outros elaborassem significados raciais para sua candidatura, evitando se colocar a respeito da luta pela igualdade travada pelos negros. Sutilmente, fazia referências à avó materna branca - e dedicava-se a discutir e apresentar propostas para a solução dos problemas políticos e econômicos do país, desviando a ênfase dada - por outros - à sua raça. Afinal, o tempo todo sua imagem era aquela de um indivíduo que desafia a história e, portanto, não convinha adentrar em um terreno tão delicado e controverso, ao qual a sociedade americana é tão sensível.

Sua estratégia foi bem sucedida, pois, além de ser o primeiro presidente afroamericano, Barack Obama será também o primeiro democrata do norte dos Estados 
Unidos da America a governar o país desde John Fitzgerald Kennedy (antes de Lyndon Johnson tornar lei o Ato de Direitos Civis, em 1964, os democratas venceram seis de oito eleições presidenciais; após 1964, perderam sete de dez). ${ }^{98}$

Relevante para este estudo foi a declaração feita pelo então candidato em discurso sobre a temática das questões raciais, proferido após a divulgação de sermões controversos de seu pastor por 20 anos - Jeremiah Wright - com o qual teve que romper relações após o incidente:

\footnotetext{
Escolhi disputar a Presidência neste momento histórico porque acredito profundamente que não podemos resolver os desafios de nossa era a não ser que o façamos juntos, a não ser que aperfeiçoemos nossa união ao compreender que, embora nossas histórias pessoais possam diferir, temos esperanças comuns. ${ }^{99}$
}

Suas palavras vêm confirmar a força com que a política de "separados, mas iguais" se enraizou na sociedade norte-americana, permeando as relações de raça e classe na era dos Direitos Civis e, ao que tudo indica, com fôlego suficiente para ter um longo caminho pela frente.

\subsection{EM TERRAS BRASILEIRAS...}

\footnotetext{
${ }^{98}$ FOLHA ON LINE - BBC BRASIL. Disponível em <http://www.folha.uol.com.br/folha/bbc $>$. Acesso em: 05 nov. 2008.

${ }^{99}$ FOLHA ON LINE MUNDO. Disponível em <http://www1.folha.uol.com.br/folha/mundo $>$. Acesso em: 05 nov. 2008.
} 
Como colocado anteriormente, Conceição Evaristo também apresenta em seu romance personagens negros que enfrentam as mesmas dificuldades daqueles retratados por Alice Walker.

Ao longo da narrativa, a autora vai registrando o impacto da opressão, a mudança do ambiente econômico em função da evolução do sistema capitalista (campo x cidade), a dissolução das referências culturais e a banalização da violência. Fala, também, sobre sofrimento, compaixão e moral, procurando levar o leitor a se colocar na pele da pessoa que sofre a fim de que compreenda a dor do outro.

Assim como a escritora norte-americana, procura denunciar, através da exposição destas vidas, a hipocrisia reinante na sociedade na qual está inserida no que se refere às relações raciais e, por conseguinte, sociais.

No entanto, um aspecto importante que as difere é a forma como a narrativa brasileira é construída. Ao contrário de Alice Walker, que descreve de uma maneira assustadoramente crua a violência doméstica - motivada por fatores externos e, portanto, alheios à vontade de seus executores - bem como as cicatrizes emocionais por ela desencadeadas, a autora brasileira apresenta uma descrição edulcorada dos problemas familiares e sociais enfrentados por seus personagens.

O romance é construído em tom intimista, altamente emotivo e com muito pouca ação das pessoas envolvidas. Seus personagens, salvo raras e brevíssimas exceções, não têm voz, ficando a narrativa a cargo de um narrador em terceira pessoa, onisciente. A heroína - ou melhor dizendo - a anti-heroína, Ponciá Vicêncio, é apresentada, e sua estória descortinada, através de suas memórias. É através deste processo de lembrar, sempre conduzido pela voz narrativa, que o leitor toma conhecimento dos fatos envolvendo a personagem e sua família. É também a memória que se configura como o 
meio utilizado pela personagem para alcançar o autoconhecimento, bem como informar o leitor a respeito da história pessoal de cada uma das pessoas que compõem seu círculo de relacionamentos.

A sociedade brasileira, paternalista, exploradora e hipócrita, é personificada pelo homem branco, representante de uma elite dominadora e opressora, porém sua figura não é materializada. Sua presença é sentida e denunciada, mas ele como que "paira no ar”, como um ente impalpável e, portanto, intangível. Assim, os membros da família Vicêncio, proprietários das terras nas quais Ponciá e seus ancestrais sempre trabalharam, e cujo sobrenome foi estendido aos seus familiares, não ganham forma. Também não ganham forma as pessoas da igreja que se recusaram a acolhê-la quando da sua chegada na cidade, bem como sua patroa, para quem trabalhou por anos e anos seguidos. Na mesma linha, o delegado de polícia que acaba por acolher seu irmão Luandi - quando este também resolve se aventurar na "cidade grande" é descrito apenas como um homem branco, nada mais.

Outra característica discrepante do romance brasileiro é aquela que se refere à descrição do comportamento dos homens negros com relação às suas famílias: seus atos de violência em geral não são tão abusivos quanto os atos daqueles homens apresentados no romance norte-americano, e são, via de regra, devidamente aceitos e desculpados.

A solução final apresentada para a personagem principal é a imersão total na loucura, que se configura como a perda completa da identidade, e para os demais personagens - o irmão e a mãe - é o retorno para o campo, onde voltarão a viver nas mesmas condições precárias de antes e poderão cuidar da agora absolutamente fragilizada Ponciá. Assim, distantes da cidade, eles se afastarão de um tipo de racismo e 
voltarão para outro através da reintegração à subserviência da vida na fazenda, onde acreditam que, com a família novamente reunida, seus males acabarão.

A partir destas observações pode-se afirmar que os modos através dos quais a ficção ecoa a realidade brasileira, no que concernem as relações raciais, têm sua origem e sustentação em dois princípios: a democracia racial e o homem cordial.

Como apontado nas páginas iniciais deste capítulo, o regime escravocrata brasileiro, bem como a abolição da escravidão e seus desdobramentos, tiveram características distintas. Some-se a isso sua condição de ex-colônia portuguesa, cenário de um processo de exploração predatória, com sua vida econômica montada para enriquecer a metrópole, sem que houvesse por parte dos portugueses qualquer comprometimento ou intenção de aqui se formar uma nação. ${ }^{100}$

Tendo os portugueses, durante séculos, como a expressão máxima de autoridade e um sistema escravocrata nacional, o Brasil seguiu impávido sua jornada rumo ao futuro, transformando-se de colônia a império e, finalmente, a República. Durante todo o processo a população branca manteve-se sempre coesa - com exceção de alguns poucos conflitos entre abolicionistas e escravagistas - enquanto perpetuava a dominação racial, a princípio do escravo, e depois do negro liberto.

A questão racial somente adquiriu relevância, de forma avessa, quando a elite brasileira, agora na condição de cidadãos de um país livre, começou a se incomodar com a imagem externa da nação. Fortemente influenciada pelos valores da cultura européia, sentia-se extremamente desconfortável com o grau de miscigenação da população brasileira, marcada pelo grande número de negros, mulatos, cafuzos e caboclos. Esta população mestiça era motivo de vergonha e constrangimento,

\footnotetext{
${ }^{100}$ Embora seja de conhecimento geral, é interessante lembrar, a título de comparação, que o mesmo não aconteceu com a América do Norte, que foi ocupada inicialmente por pessoas perseguidas por motivos políticos e religiosos, como os puritanos da Inglaterra, Holanda, Irlanda e Escócia, e que lá pretendiam se estabelecer e criar um novo país. Este fato é altamente significativo, pois fez toda a diferença no proces so de formação e consolidação dos Estados Unidos da América como país livre e democrático.
} 
considerada um empecilho para que o Brasil se desenvolvesse e adquirisse status de país próspero e civilizado.

Várias foram as tentativas de se promover o branqueamento dos brasileiros, desde o banimento da imigração de negros - ocorrido no período imediatamente posterior à abolição da escravidão - passando pelo grande incentivo dado à imigração de europeus, e culminando com o acontecimento que Octavio Ianni chamou de grande naturalização. $^{101}$

A combinação de atraso econômico, alto grau de miscigenação racial e pobreza cultural era motivo de preocupação latente também entre os intelectuais brasileiros, como aponta Antonio Cândido:

[...] marcando a ambigüidade do intelectual brasileiro que aceitava e rejeitava a sua terra, dela se orgulhava e se envergonhava, nela confiava e dela desesperava, oscilando entre o optimismo idiota das visões oficiais e o sombrio pessimismo devido à consciência do atraso. $^{102}$

As diversas tentativas de se explicar o Brasil e os brasileiros levaram à elaboração de várias teorias. Dentre elas, tem importância capital - em função de sua grande repercussão - a teoria da "democracia racial", apresentada e discutida por Gilberto Freyre em seu mais famoso estudo sobre o país, Casa-grande \& senzala, publicado em 1933.

\footnotetext{
${ }^{101}$ Essa medida, que transformava o imigrante em cidadão brasileiro, com plenos direitos políticos e legais, foi estabelecida pela Constituição de 24 de fevereiro de 1891. Em seu artigo 64, parágrafo quarto, ela estabelecia: "São cidadãos brasileiros: os estrangeiros que, achando-se no Brasil aos 15 de novembro de 1889, não declararam, dentro em seis meses depois de entrar em vigor a Constituição, o ânimo de conservar a nacionalidade de origem."

${ }_{102}$ CANDIDO, A. De cortiço a cortiço. In: O discurso e a cidade. São Paulo: Duas Cidades. 1993. p. 139. $316 \mathrm{p}$.
} 
Naquele estudo, o sociólogo apresentava uma sociedade permeada por relações cordatas entre negros e brancos. Justificava a democracia vigente nas relações raciais como conseqüência das experiências que os portugueses haviam tido anteriormente com as populações africanas, o que conferiria um padrão mais humanitário ao regime escravocrata praticado no Brasil. Além disso, alegava que a escassez de mulheres na colônia portuguesa e o tipo de vida sexual praticado sob o escravismo, bem como a formação de uma sociedade marcadamente patriarcal, foram elementos determinantes para as cordiais relações raciais aqui reinantes, fato este que distinguiria o Brasil de outras sociedades no continente americano onde a escravatura foi marcada por relações de domínio violentas e opressivas, como nos Estados Unidos da America, por exemplo.

A obra - polêmica - teve grande repercussão nacional e internacional, assumindo a paternidade do mito da "democracia racial" no Brasil. Esta construção da imagem de uma sociedade original e atípica, que aceitava e respeitava as diferenças, foi um verdadeiro "presente dos deuses" para a classe dominante. A forte miscigenação deixou de ser motivo de constrangimento, passando a ser um símbolo das relações humanas e cordiais da população, onde não havia lugar para a discriminação e nem para o racismo, tão presentes e criticados em outras partes do mundo.

Em 1936 outro livro, cujo objetivo também era analisar e compreender o Brasil e sua cultura, foi publicado: tratava-se de Raízes do Brasil, de autoria de Sérgio Buarque de Holanda. Em sua obra, igualmente polêmica, o autor lançava o conceito de "homem cordial", não como um elogio, mas sim como uma característica do homem brasileiro que precisaria ser modificada. Ele o apresentava como sendo o resultado de nossa história como colonos da Coroa Portuguesa e membros de uma sociedade cuja estrutura social, política e econômica era instável em função de valores patriarcais e escravagistas. Para esse homem seria muito difícil distinguir o Estado da família, o 
público do privado, fato este que, para o autor, seria um obstáculo para a constituição de um Estado moderno. Assim, a cordialidade seria a sua forma errônea, de certo modo primitiva, de conviver socialmente e não um aspecto agradável do seu comportamento.

Porém, o conceito de "homem cordial" - como mais uma característica da benevolência da população brasileira - casava-se perfeitamente com o conceito de "democracia racial" e é exatamente a combinação de ambos que tem mediado as relações de raça e classe social na sociedade brasileira desde então. O mito da "democracia racial", que construiu a imagem de aceitação e de mobilidade social, promoveu a quietude e a alienação da população negra, enquanto as práticas efetivas da sociedade brasileira foram intensificando as desigualdades. Esta forma sutil e eficiente de dominação provocou efeitos psicológicos graves na medida em que promoveu na população negra e seus descendentes não só a aceitação de sua condição de inferioridade, mas também da sua responsabilidade pelos seus sucessivos fracassos.

[...] A ideologia de uma classe dirigente, sabemos disso, faz-se adotar em grande parte pelas classes dirigidas. Ora, toda ideologia de combate inclui como parte integrante dela mesma uma concepção do adversário. Ao concordar com essa ideologia, as classes dominadas confirmam, de certa maneira, o papel que lhes foi atribuído. O que explica, entre outras coisas, a relativa estabilidade das sociedades: a opressão é, por bem ou por mal, tolerada pelos próprios oprimidos. ${ }^{103}$

As observações sobre os mecanismos da sociedade brasileira, aliadas à consideração apresentada por Albert Memmi acerca das relações de dominação,

\footnotetext{
${ }^{103}$ MEMMI, Albert. Retrato do colonizado precedido pelo retrato do colonizador. São Paulo: Paz e Terra, 1989. p. 83. 127 p.
} 
remetem diretamente ao romance Ponciá Vicêncio e às questões levantadas sobre o posicionamento da autora e a pertinência das soluções por ela apresentadas.

A convivência com o mito da "democracia racial" e com o mito do "homem cordial" de fato impossibilita o indivíduo de visualizar e apontar seu opressor com clareza, visto que ele está camuflado e diluído dentro do sistema. Como consequiência o enfrentamento se torna praticamente impossível, uma vez que, ao não enxergá-lo e não conseguir apontar suas estratégias de dominação, os afro-descendentes não têm um alvo concreto para se contrapor, tampouco condições de elaborar formas de resistência.

A difícil tarefa de reconhecer e dar forma aos agentes opressivos do sistema dominante torna-se ainda mais angustiante quando se verifica que a sociedade brasileira - sempre pródiga em seu objetivo de gerar métodos de perpetuação de negligências sociais - conseguiu mais um feito: associar definitivamente sua vocação patriarcal e paternalista com a ideologia do favor, apresentada por Roberto Schwarz como um mecanismo de relações sociais desenvolvido no Brasil Império e que associava definitivamente o latifundiário àquela parcela da população que não era escrava mas também não fazia parte do rol de proprietários.

Acreditamos que esta relação ambígua, quase simbiótica, sofreu transformações e foi se aperfeiçoando ao longo dos vários estágios políticos e econômicos pelos quais o país passou e permanece até os dias atuais como uma característica marcante da cultura brasileira.

Seus tentáculos estão presentes nas relações entre patrões e empregados, principalmente aqueles mais humildes, entre o Estado e seus funcionários e nas políticas públicas adotadas pelos governantes do país, inclusive aqueles que se colocam como sendo de esquerda e, portanto, mais comprometidos com a construção de uma sociedade mais igualitária. 
Isto posto, verifica-se o alto grau de complexidade da tarefa enfrentada por aqueles que se propõem a retratar, através da ficção, a realidade das camadas mais humildes da população brasileira: democracia racial, homem cordial, patriarcalismo, paternalismo, ideologia do favor - uma combinação perigosa e altamente "inflamável”. Um ambiente difuso, como que envolto em neblina, onde vislumbrar silhuetas é o máximo que se pode alcançar enquanto se caminha por um campo minado; este é o cenário que o escritor tem pela frente.

Justifica-se, deste modo, a dificuldade da autora em plasmar os personagens que no enredo se configuram como opressores. Sua heroína não consegue identificá-los com clareza, advindo desta dificuldade a sua falta de voz na narrativa, a sua apatia e a conseqüente loucura.

Da mesma forma, a aceitação passiva da impossibilidade de ascensão financeira e social com vistas ao reconhecimento da igualdade de direitos revela a percepção de Luandi de que ele é, de fato, inferior, e que a melhor atitude a tomar é a volta para o trabalho pesado e a subserviência da vida no campo.

A força desta ideologia na cultura brasileira e a forma arraigada como ela se instalou ao longo dos anos se faz presente no romance de uma maneira muito clara: assim como na vida real, o leitor se depara com um núcleo de perdedores, todos bem intencionados e dóceis, porém incapazes de reivindicar seus direitos simplesmente porque não sabem a quem recorrer, o que reivindicar e como se organizar, pois "[...] as forças dominantes da sociedade evitam a radicalização da crítica social e a possibilidade de imaginar alternativas para o cotidiano." (Willis, 1997, p. 192) 


\section{BIBLIOGRAFIA}

ABDALA Jr., Benjamin. Fronteiras múltiplas, identidades plurais. São Paulo: SENAC, 2002. 179 p.

ACHEBE, Chinua. The African writer and the English language. In: Morning yet on creation Day. London: Verso, 1975.

ADORNO, T. W. Posição do narrador no romance contemporâneo. In: Benjamin, Adorno, Horkheimer, Habermas. Coleção os Pensadores. São Paulo: Abril, 1975. $290 \mathrm{p}$.

AHMAD, Aijaz. Teoria literária e "literatura do terceiro mundo": alguns contextos. In: Linhagens do presente. São Paulo: Boitempo, 2002. 287 p.

ANDERSON, Perry. As origens da pós-modernidade. Rio de Janeiro: Jorge Zahar, 1999. $159 \mathrm{p}$.

ARONOWITZ, S. When the New Left Was New. In: The death and rebirth of American radicalism. Durham: Duke University Press, 1992.

AUERBACH, E. Mimesis. São Paulo: Perspectiva, 1994. 507 p.

BAKER Jr., Houston. A. Blues, ideology and afro-american literature. Chicago: The University of Chicago Press, 1984. 227 p.

BAKHTIN, Mikhail. The dialogic imagination. Austin: University of Texas Press. 1981. $433 \mathrm{p}$.

BAKHTIN, Mikhail. Questões de literatura e de estética. São Paulo: UNESP, 1993. $439 \mathrm{p}$.

BAKHTIN, Mikhail. Estética da criação verbal. São Paulo: Martins Fontes, 2000. $421 \mathrm{p}$.

BARBOSA, Maria J. S. Prefácio. In: EVARISTO, Conceição. Ponciá Vicêncio. Belo Horizonte: Mazza, 2005. 132 p.

BENJAMIN, W. Crise do romance. In: Documentos de cultura, documentos de barbárie (seleção e apresentação de Willi Bolle). São Paulo: Cultrix/EDUSP, 1986.

BENJAMIN, W. O narrador. In: Benjamin, Adorno, Horkheimer, Habermas. Coleção os Pensadores. São Paulo: Abril, 1975. 290 p.

BERNARDO, Teresinha. Memória em branco e negro: olhares sobre São Paulo. São Paulo: UNESP, 1998. 207 p. 
BERNARDO, Teresinha. Negras, mulheres e mães. São Paulo: EDUC, 2003. 194 p.

BIGSBY, C. W. E.; THOMPSON, R. The black experience. In: BRADBURY, M.; TEMPERLEY, H. (Eds.). Introduction to American studies. Essex: Longman, 1995. BOOTH, Wayne. Point of view. In: STEVICK, Philip. The theory of the novel. New York: The Free Press, 1967.

BOSI, Alfredo. História concisa da literatura brasileira. São Paulo: Cultrix, 1977. $571 \mathrm{p}$.

BOSI, Alfredo. Dialética da colonização. São Paulo: Cia das Letras, 1994. 404 p.

BRESCIANI, Maria Stella. A casa em Gilberto Freyre: síntese do ser brasileiro? In: CHIAPPINI, Lígia.; BRESCIANI, M. S. (Orgs.). Literatura e cultura no Brasil: identidades e fronteiras. São Paulo: Cortez, 2002. 328 p.

BROGAN, Hugh. Slavery and its consequences, the war about slavery, reconstruction. In: The Penguin history of the United States of America. London: Penguin, 1985. $740 \mathrm{p}$.

BUTLER-EVANS, Elliot. History and genealogy in Walker's The Third Life of Grange Copeland and Meridian. In: GATES JR., H. L.; APPIAH, K. A. (Eds.). Alice Walker: Critical perspectives, past and present. New York: Amistad, 1993. 368 p.

CANDIDO, Antonio. Formação da literatura brasileira. Belo Horizonte: Ed. Itatiaia, 1975. $365 \mathrm{p}$.

CANDIDO, Antonio. A educação pela noite \& outros ensaios. São Paulo: Ática, 1989. $223 \mathrm{p}$.

CANDIDO, Antonio. O discurso e a cidade. São Paulo: Duas Cidades, 1993. 316 p.

CANDIDO, Antonio et al. A personagem de ficção. São Paulo: Perspectiva, 1995. 119 p.

CARVALHO, Alfredo L. C. O foco narrativo. In: Foco narrativo e fluxo de consciência - questões de teoria literária. São Paulo: Pioneira, 1981.

CEVASCO, Maria Elisa. Para Ler Raymond Williams. São Paulo: Paz e Terra, 2001. $356 \mathrm{p}$.

CEVASCO, Maria Elisa. Dez lições sobre estudos culturais. São Paulo: Boitempo, 2003. $188 \mathrm{p}$.

COUTINHO, Eduardo F. Revisitando o pós-moderno. In: GUINSBURG, J.; BARBOSA, A. M. (Orgs.). O pós-modernismo. São Paulo: Perspectiva, 2005. 
CHRISTIAN, Barbara. Alice Walker. In: DAVIS, Thadious M.; HARRIS, Trudier (Eds). Dictionary of literary biography. Vol. 33: Afro-american fiction writers after 1955. Detroit: Bruccoli Clark. 1984. 319 p.

CHRISTIAN, Barbara. The Black woman artist as wayward. In: BLOOM, H. (Ed.). Alice Walker. New York: Chelsea House Publishers, 1989. 245 p.

CHRISTIAN, Barbara. CHRISTIAN, B. Novels for everyday use. In: GATES JR., H. L.; APPIAH, K. A. (Eds.). Alice Walker: Critical Perspectives, Past and Present. New York: Amistad, 1993. 368 p.

COOKE, Michael. The centering self. In: GATES JR., H. L.; APPIAH, K. A. (Eds.). Alice Walker: Critical Perspectives, Past and Present. New York: Amistad, 1993. $368 \mathrm{p}$.

CORNWELL, Jo Anne. Searching for Zora in Alice's garden: rites of passage in Hurston's Their eyes were watching God and Walker's The third life of Grange Copeland. In: HOWARD, Lillie P. (Ed.). Alice Walker and Zora Neale Hurston, the common bond. Westport: Greenwood Press, 1993. 161 p.

D’ADESKY, Jacques. Pluralismo étnico e multiculturalismo: racismos e antiracismos no Brasil. Rio de Janeiro: Pallas, 2001.

DAVIS, Thadious M. Walker's celebration of self in southern generations. In: BLOOM, H. (Ed.). Alice Walker. New York: Chelsea House Publishers, 1989. 245 p.

DUARTE, Eduardo de Assis. Memória e ficção na narrativa feminina afro-brasileira. In: MONTEIRO, M. C.; LIMA, T. M. O. (Orgs.). O estético e o político: a mulher nas literaturas clássicas e vernáculas. Florianópolis: Ed. Mulheres, 2005.

DU BOIS, W.E.B. The souls of black folk. New York: Dover, 1994. 165 p.

EAGLETON, Terry. Teoria da literatura: uma introdução. São Paulo: Martins Fontes, 1983. 240 p.

EAGLETON, Terry. Marxism and literary criticism. Los Angeles: UCLA Press, 1984. 83 p.

EAGLETON, Terry. Introduction. In: Raymond Williams: critical perspectives. Oxford: Basil Blackwell. 1989.

EAGLETON, Terry. The significance of theory. Oxford: Blackwell, 1992. 102 p.

ERICKSON, P. "Cast out alone/to heal/and re-create/ourselves": family-based identity in the work of Alice Walker. In: BLOOM, H. (Ed.). Alice Walker. New York: Chelsea House Publishers, 1989. 245 p.

EVARISTO, Conceição. Ponciá Vicêncio. Belo Horizonte: Mazza, 2005. 132 p. 
EVARISTO, Conceição. Becos da memória. Belo Horizonte: Mazza, 2006. 167 p.

FANON, Frantz. The wretched of the earth. London: Penguin, 1969. 255 p.

FANON, Frantz. Pele negra, máscaras brancas. Salvador: Fator, 1983. 190 p.

FERNANDES, Florestan. A integração do negro na sociedade de classes - o legado da raça branca. São Paulo: Dominus, 1965. Volume I. 261 p.

FERNANDES, Florestan. A integração do negro na sociedade de classes - no limiar de uma nova era. São Paulo: Dominus, 1965. Volume II. 393 p.

FREIRE, Gilberto. Casa grande \& senzala. São Paulo: Record, 1998. 569 p.

FRY, Peter. A persistência da raça. Rio de Janeiro: Ed. Civilização Brasileira, 2005. $348 \mathrm{p}$.

FRYE, Northrop. Anatomia da crítica. São Paulo: Cultrix, 1973. 363 p.

GILROY, Paul. O Atlântico negro. São Paulo: Editora 34, 2001. 427 p.

GUIMARÃES, Geni. Leite do peito. Belo Horizonte: Mazza. 2001. 104 p.

GUIMARÃES, Ruth. Água Funda. Rio de Janeiro: Nova Fronteira, 2003. 238 p.

HALL, Stuart. A identidade cultural na pós-modernidade. Rio de Janeiro: DP\&A Ed., 2001.

HAUSER, Arnold. História social da literatura e da arte. São Paulo: Mestre Jou, 1982. Tomo II. 1151 p.

HOBSBAWN, Eric. Era dos extremos: o breve século XX (1914-1991). São Paulo:

Cia das Letras, 1996. 598 p.

HOBSBAWN, Eric J. Deveriam os pobres se organizar? In: Mundos do trabalho. São Paulo: Paz e Terra, 2005. 460 p.

HOLANDA, Sergio B. Raízes do Brasil. Rio de Janeiro: Jose Olympio, 1975. 155 p.

IANNI, Octavio. As metamorfoses do escravo. São Paulo: Difusão Européia do Livro, 1962. $312 \mathrm{p}$.

IANNI, Octavio. Raças e classes sociais no Brasil. Rio de Janeiro: Ed. Civilização Brasileira, 1972. 248 p.

IANNI, Octavio. Escravidão e racismo. São Paulo: Hucitec, 1988. 190 p.

IANNI, Octavio. Pensamento social no Brasil. São Paulo: EDUSC, 2004. 366 p.

JAMESON, F. Periodizing the Sixties. In: The ideologies of theory. Minneapolis: University of Minnesota Press, 1986.

JAMESON, F. Marxism and form. Princeton: Princeton University Press, 1971.

JAMESON, F. Third world literature in the era of multinational capitalism. In: Social Text 15. Fall, 986. p. $65-88$. 
JAMESON, Fredric. O inconsciente político. São Paulo: Ática, 1992. 317 p.

JONES, Maldwyn A. The Civil War, 1861-1865, The troubled years, 1960-1980, The new South and White supremacy, 1877-1914. In: The short Oxford history of the modern world - the limits of liberty: American history - 1607/1992. New York: OUP, 1995.

KABENGELE, Munanga. Negritude: usos e sentidos. São Paulo: Ática, 1988. 88 p. KURZ, Robert. O colapso da modernização. São Paulo: Paz e Terra, 1999.

LINDSEY, Howard O. A history of Black America. London: Bison Books, 1994. 160 p.

LUKÁCS, Georg. A reificação e a consciência do proletariado. In: História e consciência de classe: estudos sobre a dialética marxista. São Paulo: Martins Fontes, 2003. 598 p.

MARX, Karl. O capital. Rio de Janeiro: Civilização Brasileira, 2004. 22ª . Vol. 1, Partes I, II, III. 571 p.

MARX, Karl. O dezoito brumário de Louis Bonaparte. São Paulo: Centauro Ed., 2004. 149 p.

MASON, Jr., Theodore O. The dynamics of enclosure. In: GATES Jr., Henry L.; APPIAH, K. A. (Eds.). Alice Walker: critical perspectives, past and present. New York: Amistad, 1993. 368 p.

MAUK, David.; OAKLAND, John. The people: women and minorities. In: American civilization: an introduction. London: Routledge. 1977.

MEMMI, Albert. Retrato do colonizado precedido pelo retrato do colonizador. São Paulo: Paz e Terra, 1989. 127 p.

MOISÉS, Massaud. Romance. In: A criação literária - Prosa I. São Paulo: Cultrix, 1997. $355 \mathrm{p}$.

MUNANGA, Kabengele. Negritude, usos e sentidos. São Paulo: Ática, 1988. 88 p.

O'BRIAN, John. Alice Walker: na interview. In: GATES Jr., Henry L.; APPIAH, K. A. (Eds.). Alice Walker: critical perspectives, past and present. New York: Amistad, 1993. $368 \mathrm{p}$.

PESAVENTO, Sandra. Paraísos cruzados: encantamento e desencantamento do mundo em Gilberto Freyre e Sérgio Buarque de Holanda. In: CHIAPPINI, Lígia.; BRESCIANI, M. S. (Orgs.). Literatura e cultura no Brasil: identidades e fronteiras. São Paulo: Cortez, 2002. 328 p. 
PRATT, Mary Louise. Scratches on the face of the country. In: Critical Inquiry. Autumn. 1985.

PRIORE, Mary Del (Org.). Revisão do paraíso. Rio de Janeiro: Ed. Campus, 2000. 366 p.

PROENÇA FILHO, Domício. A Trajetória do Negro na Literatura Brasileira. In Estudos Avançados, Revista do Instituto de Estudos Avançados da Universidade de São Paulo, Dossiê O Negro No Brasil. São Paulo: IEA, 2004. Volume 18. Número 50 .

RANSON, Edward.; HOOK, Andrew. The old South. In: BRADBURY, Malcolm.; TEMPERLEY, Howard (Eds). Introduction to American studies. Essex: Longman, 1995.

REIS, Eneida de A. Mulato: negro/não negro e/ou branco/não branco. São Paulo: Altana, 2002. 103 p.

REIS, Maria Firmina dos. Úrsula. Florianópolis: Ed. Mulheres; Belo Horizonte: PUC Minas, 2004. 281 p.

RESENDE, Beatriz. Os Estudos Culturais e a Política dos Saberes. In: GUINSBURG, J.; BARBOSA, A. M. (Orgs.). O pós-modernismo. São Paulo: Perspectiva, 2005.

ROTH, John K. (Ed.). Alice Walker. In: American diversity, American identity. New York: Henry Holt \& Company, 1995.

SADER, Emir. A vingança da história. São Paulo: Boitempo, 2003.

SAID, Edward. Cultura e imperialismo. São Paulo: Cia das Letras, 1999. 459 p.

SARTRE, J. P. Que é a literatura? São Paulo: Ática, 1989. 231 p.

SOUZA, Jessé (Org.). Multiculturalismo e racismo, uma comparação Brasil Estados Unidos. Brasília: Paralelo 15, 1997. 275 p.

SCHWARZ, Roberto. Que horas são? São Paulo: Cia. das Letras, 1989. 180 p.

SCHWARZ, Roberto. Um mestre na periferia do capitalismo. São Paulo: Duas Cidades, 1991. $227 \mathrm{p}$.

SCHWARZ, Roberto. Ao vencedor as batatas. São Paulo: Duas Cidades, 1992. 169 p. SCHWARZ, Roberto. Duas meninas. São Paulo: Cia. das Letras, 1997. 144 p.

SCHWARZ, Roberto. Seqüiências brasileiras. São Paulo: Cia. das Letras, 1999. 249 p. SHOWALTER, Elaine et al. (Eds.). Alice Walker. In: Modern American women writers. New York: Macmillan, 1993. 416 p. 
STANFORD, Ann F. Dynamics of change: men and co-feeling in the fiction of Zora Neale Hurston and Alice Walker. In: HOWARD, Lillie P. (Ed.). Alice Walker and Zora Neale Hurston: the common bond. Westport: Grenwood Press, 1993. 161 p.

ULLSTEIN, Susan (Ed.). Martin Luther King. Essex: Longman, 1990. 120 p.

VOGLER, Christopher. A jornada do escritor. Rio de Janeiro: Ampersand, 1992. 360 p.

XAVIER, Lívio. O artesanato no Ceará. In BARDI, Lina Bo. Tempos de grossura: o design no impasse. São Paulo: Instituto Lina Bo e P. M. Bardi, 1994.

WALKER, Alice. In love and trouble. New York: Harcourt Brace \& Company, 1973. $138 \mathrm{p}$.

WALKER, Alice. You can't keep a good woman down. New York. Harcourt Brace \& Company, 1981. 167 p.

WALKER, Alice. In search of our mothers' gardens. New York: Harcourt Brace \& Company, 1984. 397 p.

WALKER, Alice. The color purple. New York: Pocket Books, 1985. 295 p.

WALKER, Alice. Meridian. New York: Pocket Books, 1986. 220 p.

WALKER, Alice. Living by the word. New York: Harcourt Brace \& Company, 1988. $193 \mathrm{p}$.

WALKER, Alice. The temple of my familiar. New York: Pocket Books, 1990. 417 p.

WALKER, Alice. Possessing the secret of joy. New York: Washington Square Press, 1997. 288 p.

WALKER, Alice. By the light of my father's smile. New York: Ballantine Books, 1998. $222 \mathrm{p}$.

WALKER, Alice. The third life of Grange Copeland. New York: Harcourt Books, 2003. 318 p.

WASHINGTON, Mary Helen. An essay on Alice Walker. In: GATES Jr., Henry L.; APPIAH, K. A. (Eds.). Alice Walker: critical perspectives, past and present. New York: Amistad, 1993. 368 p.

WEBER, Max. A ética protestante e o espírito do capitalismo. São Paulo: Martin Claret, 2001. 224 p.

WEINSTEIN, J. Ambiguous legacy - the left in American politics. New York: New Viewpoints, 1975.

WILLIAMS, R. O campo e a cidade. São Paulo: Cia das Letras, 1990. 439 p. 
WILLIAMS, R. Drama in a dramatized society. In: Writing in society. London: Verso, 1991.

WILLIAMS, R. Marxism and literature. Oxford: OUP, 1992. 215 p.

WILLIAMS, R. Base and superstructure in Marxist cultural theory. In: Problems in materialism and culture. London: Verso, 1980.

WILLIS, Gladys J. Alice Walker's influence on womanist theology: a minority response. USA: Xlibris, 2006. 64 p.

WILLIS, Susan. Walker's women. In: BLOOM, H. (Ed.). Alice Walker. New York: Chelsea House Publishers, 1989. 245 p.

WILLIS, Susan. Black women writers: taking a critical perspective. In: Making a difference: feminist literary criticism. New York: Routledge, 1994.

WILLIS, Susan. Cotidiano: para começo de conversa. Rio de Janeiro: Graal, 1997. $230 \mathrm{p}$.

WILSON, Mary Ann. "That which the soul lives by": spirituality in the works of Zora Neale Hurston and Alice Walker. In: HOWARD, Lillie P. (Ed.). Alice Walker and Zora Neale Hurston: the common bond. Westport: Grenwood Press, 1993. $161 \mathrm{p}$.

WILSON, Sharon. A conversation with Alice Walker. In: GATES JR., H. L.; APPIAH, K. A. (Eds.). Alice Walker: Critical Perspectives, Past and Present. New York: Amistad, 1993. 368 p.

WILLIS, Susan. Evidências do real. São Paulo: Boitempo, 2008. 127 p.

WOOD, Ellen Meiksins. Sociedade civil e política de identidade. In: Democracia contra capitalismo: a renovação do materialismo histórico. São Paulo: Boitempo, 2003. 260 p. 